\title{
Humusica 2, article 19: Techno humus systems and global change - Conservation agriculture and 4/1000 proposal $^{*}$
}

Augusto Zanella ${ }^{a,+}$, Cristian Bolzonella ${ }^{a}$, Jeff Lowenfels ${ }^{b}$, Jean-François Ponge ${ }^{c}$, Marcel Bouchéd, Debasish Saha ${ }^{\mathrm{e}}$, Surinder Singh Kukal ${ }^{\mathrm{e}}$, Ines Fritz ${ }^{\mathrm{f}}$, Allan Savory ${ }^{\mathrm{g}}$, Manuel Blouin ${ }^{\mathrm{h}}$, Luigi Sartori ${ }^{\mathrm{a}}$, Dylan Tatti', Liv Anna Kellermanni, Peter Trachsel', Stéphane Burgos', Budiman Minasny", Masanobu Fukuoka, ${ }^{\mathrm{a}, \mathrm{l}}$

${ }^{a}$ University of Padua, Italy

${ }^{\mathrm{b}}$ GWA, The Association for Garden Communicators, New York, NY

${ }^{c}$ Muséum National d'Histoire Naturelle, Paris, France

${ }^{\mathrm{d}}$ Institut National de la Recherche Agronomique, Montpellier, France

${ }^{\mathrm{e}}$ Pennsylvania State University, State College, PA

${ }^{\mathrm{f}}$ Universität für Bodenkultur Wien, Austria

${ }^{\mathrm{g}}$ Allan Savory Institute Boulder, $\mathrm{CO}$

${ }^{\mathrm{h}}$ Université de Bourgogne, Dijon, France

'BFH University of Applied Sciences, Zollikofen, Switzerland

${ }^{j}$ Amt für Landwirtschaft und Natur des Kantons Bern, Zollikofen, Switzerland

${ }^{\mathrm{k}}$ University of Sydney, Australia

'Masanobu Fukuoka (1913-2008) was a Japanese farmer and philosopher celebrated for his natural farming (Fukuoka, 1985)

Keywords: Homo sapiens; Charles Darwin; Masanobu Fukuoka; Allan Savory; Jeff Lowenfels; Marcel Bouché; Matt Damon; Humusica; Natural farming; Earthworms; Humus; Soil; Peat; Agriculture; Organic agriculture; Conservation agriculture; Soil organic carbon; Soil aggregates; Soil C sequestration

\footnotetext{
" Background music while reading: The Doors-Riders On The Storm (ORIGINAL!) - driving with Jim: https://www.youtube.com/watch?v=IS-af9Q-zvQ\&list=RDIS-af9Q-zvQ\&t=3.

${ }^{\dagger}$ Corresponding author.

E-mail addresses: augusto.zanella@unipd.it (A. Zanella), cristian.bolzonella@unipd.it (C. Bolzonella), jefflowenfels@gmail.com (J. Lowenfels), ponge@mnhn.fr (J.-F. Ponge), marcbouche@hotmail.fr (M. Bouché), debasish992@gmail.com (D. Saha), sskukal@rediffmail.com (S.S. Kukal), ines.fritz@boku.ac.at (I. Fritz), hmi@holisticmanagement.org (A. Savory), manuel.blouin@agrosupdijon.fr (M. Blouin), sartori.luigi@unipd.it (L. Sartori), dylan.tatti@bfh.ch (D. Tatti), liv.kellermann@bfh.ch (L.A. Kellermann), peter.trachsel@vol.be.ch (P. Trachsel), stephane.burgos@bfh.ch (S. Burgos), budiman.minasny@sydney.edu.au (B. Minasny).
} 


\section{ABSTRACT}

Philosophy can overlap pedology. It is not casual that life begins and finishes in the soil. We separated the concepts of Humipedon, Copedon and Lithopedon. Some sections were dedicated to the founders of the movement for a new type of agriculture (agroecology). They simply proclaim to accompany the process of natural evolution instead of spending a lot of energy in hunting competitor organisms with pesticides or boosting the soil with mineral fertilisation and tillage. The core of the article is built on a biological concept of the soil and shows researches supporting this view. After pointing to the soil structure and illustrating its natural genesis, explaining which cultural conditions may improve its quality, we finished the article with economic considerations, combining at planet level a program of soil restoration with a mitigation of the greenhouse effect. What a reader should have in mind at the end of the article: soil organisms have a prominent positive influence on soil structure and fertility; their mass is proportional to the amount of soil organic matter; it is possible to counteract climate warming by using soil as sink of $C$. We estimated that the Agro Humipedons of a European economically active region could sink about 13 or $20 \%$ of its emissions, by switching from conventional to minimum or no tillage during the coming 40 years. At planetary level, a wellprogrammed 4 per 1000 action can even be more efficient and might compensate part of the global greenhouse gas effect. 


\section{Introduction}

In Humusica 1, article 1: Essential bases - Vocabulary, the soil profile is divided into Humipedon, Copedon and Lithopedon (Figs. 1a and b). Each sub-unit of soil profile includes different soil horizons. We suggest to observe each sub-unit at different space and time scales (Table 1). In fact, each sub-unit is generated by specific biological and abiotic processes (Figs. 1c-e). Adapted disciplines are necessary for efficiently studying each part of the soil profile. For a long time (Darwin, 1881; Jenny, 1941), organisms are recognized as important factors of soil formation. Soil is increasingly considered as a living entity. In recent years, soil ecology and soil evolution mixed, time scales of ecological and evolutionary processes fitting together (review in: Barea et al., 2005; Barot et al., 2007; Bhatia, 2008; Brussard, 2012; Buckley and Schmidt, 2003; Copley, 2000; Fitter, 2005; Gewin, 2006; Gobat et al., 2010; Kirchmann and Thorvaldsson, 2000; Lynch et al., 2004; Pinton et al., 2007). The concept of ecological inheritance is emerging with strength (Bonduriansky and Day, 2009; Odling-Smee et al., 2013; Nikol'skii, 2014; Ademe, 2015).

If soil is a complex ecosystem composed of interdependent ecological niches, the upper part of the soil (Humipedon) and its soil organisms, should play a prominent role in agriculture (Abbott and Murphy, 2003; Ammann, 2005; Benckiser, 1997; Fontaine and Barot, 2005; Johansson et al., 2004; Lal, 2014; Manlay et al., 2007; Minasny et al., 2017a and b; Paustian et al., 2016; Schlesinger, 2000; Stockmann et al., 2013). Agriculture interferes with the soil at space and time scales of the Humipedon (Table 1).

In anthropogenic soils, conventional agriculture (ploughing, mineral fertilisation, herbicides/pesticides) and high grazing pressure may alter the original structure of the Humipedon (Humusica 1, articles 15 and 16). Compost or mulch applications, minimum tillage or no tillage and adjusted grazing pressure may restore a quasi-natural equilibrium, feeding and exploiting the soil not as an abiotic substrate but as a living system. Soil could indeed be viewed as a "diffuse organism", a quite invisible amoeba acting as an interface between organic/mineral matter and plants. This diffuse organism is composed of innumerable micro-, meso-, and macro-organisms. Soil aggregates generated by these organisms, made of animal droppings, root exudates, water, mineral grains, and living or dead organic matter, are strongly implicated in soil functionality (Stevenson, 1994; Domínguez, 2004; Verhulst and Govaerts, 2013; Jastrow et al., 1998; Brown et al., 2000; Butterfield et al., 2006; Gobat et al., 2010; Saha et al., 2014; Keiluweit et al., 2015; Kallenbach et al., 2016). Soil aggregates and living organisms respond to environmental influences in an integrated manner as if they are an ecosystem (Buchkowski et al., 2015; Lavelle, 2012; Manlay et al., 2007; Paul, 2016; Ponge, 2015; Schipanski et al., 2014). Anthropogenic soils show altered soil aggregates and biodiversity (Humusica 1, article 15).

In Humusica 1, article 1 begins with a question: "What's soil?" At the end of the discussion, the question becomes: "Is soil without living organisms still soil?" In "The Martian" movie (2015), Matt Damon, lost on Mars, build a greenhouse with an atmosphere allowing him to breath without a spacesuit, plants potatoes in Martian sand mixed with human faeces (opening the vacuum package containing astronaut solid wastes) and waters the whole. Thanks to this skilful tactic, he can survive by growing potatoes in a Martian garden (Fig. 2). More interesting scientific details are reported in the original Andy Weir novel (Weir, 2011). Is this Martian garden realistic? On Earth, an equivalent 
substrate is inhabited by microorganisms which co-evolved for nearly 4 billion years. In the last 500 million years, this co-evolution generated new meso- and macro-organisms, like the species of plants and animals we see all around today. On Earth microorganisms are everywhere. The more we study macro-organism functionality, the more we ascertain that they are mandatorily associated with microorganisms (Guinane and Cotter, 2013; Gruber, 2015; Leff et al., 2015; Ursell et al., 2012; Hacquard et al., 2015). The closer the conditions artificially created on Mars are to the ones we have on Earth, the higher the probability to be able to produce potatoes on this planet. We are part of a planet system (Lovelock's Gaia? http://ecolo.org/lovelock/what is Gaia.html). Very probably, we cannot survive a long period in space without our microbiome. If we want to colonize other regions of space, we must bring with us at least part of the living essence of planet Earth (Bardgett and Van der Putten, 2014; Fujimura et al., 2010; Liu et al., 2017; Ursell et al., 2012; Van der Wal and De Boer, 2017). As a consequence, soil without life is not a real soil.

Even eminent soil scientists proclaiming the inexistence of soil humus (Lehmann and Kleber, 2015) cite 12 of their references, published decades ago. Stevenson has been working on humus chemistry for more than 40 years. His book synthetizes many previously published papers. He called "dimers" the basic bricks of humic substances, because they were made of two aromatic rings. Large humic molecules were essentially made of differently connected dimers. Lehmann and Kleber (2015) cite among their references some of Stevenson's pupils (Spaccini et al., 2002; Nebbioso and Piccolo, 2012) who followed Stevenson's approach and amplified the discoveries of their master. Other important works strongly support a living concept of the soil (Andreux, 1996; Sutton and Sposito, 2005; Miltner et al., 2012; Gleixner, 2013; Kallenbach et al., 2016). Just last year, Kallenbach et al. (2016) provided the first direct evidence that soil microbes produce chemically diverse, stable soil organic matter (SOM). They proved that "SOM accumulation is driven by distinct microbial communities more so than clay mineralogy, and that microbial-derived SOM accumulation is greatest in soils with higher fungal abundances and more efficient microbial biomass production". Gleixner (2013) proved that the majority of mineral soil is in molecules derived from microbial synthesis, instead of persistence of plant-derived residues like lignin. $C$ recycled multiple times through the microbial community can be old, separating the radiocarbon age of $\mathrm{C}$ atoms from the chemical or biological lability of the molecules they comprise. In the light of these recent discoveries is the concept of soil inextricably linked with soil organism biodiversity? Can we proclaim that an aseptic soil is not a soil? Or even that agriculture (which in the end corresponds to a soil-plant system management in a given climate) is only possible thanks to a living soil?

This article would like to answer the following questions (chapter numbers heading the questions):

2. Is there a fundamental rule to be respectful while using the soil? Yes, we must understand and manage the soil as if it were a living system.

3. and 4. Are there experienced scientific references and recent data that allow better understanding and soil management? Yes, we must consider and better understand the origin and composition of soil structure.

5. How much does it cost to use the soil as a C sink? A case study in Italian croplands.

6. What about cultivated drained peat lands? A case study in Switzerland croplands. 
7. Is the $4 / 1000$ proposal a good plan for humanity? Yes, it is. Data and general overview.

\section{One general rule}

Soil biota should be different on each geological plate, because generated in co-evolution with plants and animals living confined on separate plates in given particular climatic conditions (Agnelli et al., 2004; Baveye et al., 2016; Blagodatskaya and Kuzyakov, 2013; Cartenì et al., 2016; Dawkins, 2006; Gómez-Brandón et al., 2017; Kuzyakov and Blagodatskaya, 2015; Nagler et al., 2016; Pietramellara et al., 2006, 2007, 2009). Fulthorpe et al. (1998) collected soil samples in six regions on five continents and discovered that the majority (91\%) of the genotypes were unique to the sites from which they were isolated. A total of 43 of the 44 ARDRA types were found in only one region, a few genotypes were repeatedly found in one region but not in any other continental region, suggesting that they are regionally endemic; on the contrary, Fierer and Jackson (2006) found that "microbial biogeography is controlled primarily by edaphic variables and differs fundamentally from the biogeography of 'macro' organisms." Using metagenomics sequencing to compare the composition and functional attributes of 16 soil microbial communities collected from cold deserts, hot deserts, forests, grasslands and tundra, Fierer et al. (2012) discovered that across all soils, functional beta diversity (ratio between regional and local diversities) was strongly correlated with taxonomic and phylogenetic beta diversity. Desert microbial communities were clearly distinct from non-desert communities. Studying airborne microbial communities (the "Aeropedon" hypothesis in Humusica 2, article 13), such as terrestrial plants and animals, Barberán et al. (2015) discovered that these microorganisms exhibit non-random geographic patterns. These authors identified climatic and soil variables as factors that shape the continental-scale distribution of microbial taxa. Maestre et al. (2015) found that increases in aridity reduce the diversity and abundance of soil bacteria and fungi. This fact confirms that microorganisms are related to soil and climatic variables. Furthermore, it seems probable that fragments of DNA, generated by the biodegradation of plant-animal-microbial cells in soil, are involved in plant and soil co-evolution (Mazzoleni et al., 2015a, 2015b; Cartenì et al., 2016).

These discoveries support the idea that we must protect soil biodiversity. For instance, a better agricultural practice should be to feed the soil only with indigenous organic remains (litter, compost or mulch made with organic remains collected within a single geological plate) in order to preserve, in each geological plate (in fact, in every local and relatively insulated area), a soil in harmony with its original co-evolving living organisms [Reviewer question: "What do you mean with indigenous organic remains? Do you mean for example that in North Europe compost made using organic material (ex. orange peels) coming from the Mediterranean area should not be distributed into the soil?" Answer: "Yes, probably. We think that a wine produced with grapes of a given relatively insulated area will conserve its aromatic properties only while avoiding to import it in an area with a different soil (when we import compost from geographically distant areas, we may change soil quality). Lamarck asked the right question: why is there a natural evolution? Darwin gave the right explanation: the selection of adapted individuals. But the general problem is still under investigation, individual changes being related to a global and relatively independent co-evolution: why is our solar system evolving in a given way?"]. It would be better not to introduce. Eventually, 
this concept should be considered in programs of plant and animal conservation. We should preserve ecosystems in their own geological plate, with their own soil, and not species without their soil.

Instead of focusing on plants' needs, farmers should focus on soil needs. Feeding equilibrated (and well adapted to cultivated plants) populations of soil organisms is the best way to grow crops in any type of soil, respecting the singular and natural evolution of the system. The capacity of the soil to grow crops is proportional to the capacity of soil micro-, meso-, and macroorganisms to use soil organic and mineral matter for generating soil aggregates and interacting with crops.

\section{Holistic concepts and management for agricultural purposes}

In a few pages we report three outstanding soil concepts, proposed by scientific soil lovers completely devoted to agriculture and soil protection.

\subsection{Masanobu Fukuoka}

Masanobu Fukuoka expressed theoretical and practical principles for switching from conventional to natural agriculture (Fukuoka, 1985). Basically, and in contrast with universally admitted practices, he wrote that a farmer has to study how to minimise his/her intervention in agriculture. Nature has to lead the process of production. Eventually, Man might "steer" the process, taking advantage of his experience of natural processes. This principle seems quite the opposite of conventional agriculture. Yet it is the fruit of long-term Fukuoka's researches. He thought that a farmer has to spend the largest part of his/her time in trying to understand the functioning of his/her productive system. Man should slightly intervene, as if the smaller the modifications, the better the productive system. Fukuoka's main rule is to let the agricultural system be working by itself. A farmer should favour a local natural process of production, looking for harmony between preadapted living organisms in a functional ecosystem. (review of main Fukuoka's principles in:

http://www.onestrawrevolution.net/One Straw Revolution/Massanobu Fukuoka.html).

Since the origin of life on our planet, biodiversity has been increasing, even if it passed through five main periods of mass extinction. Ecosystems automatically regenerate; they seem programmed for continuously increasing our planetary biodiversity. Meanly, all living organisms seem to have an interest in increasing the efficiency of the system in which they live, as if they knew that the best of the group is the best of the individual. Theoretical bases of this assertion are known (Leigh, 1983; Leigh and Rowell, 1995). As an example of contrasting common human thoughts a cultivated field corresponds to a protected food production company; a farmer must fight against other living organism wanting to consume his/her food, Fukuoka's meaning: starting as an inhospitable ball of fire, since more than 4 billion years planet Earth knew an independent increase in biodiversity. Farmers must seek to enter in the underlying mechanisms and use this natural evolution 
for producing food for them without disturbing the system. Like in a judo fight, a farmer should be able to "domesticate" a field crop, understanding what might be accepted as constraints by the system for ensuring a given production.

Masanobu Fukuoka's agriculture requires a lot of studies and corresponds to a long journey. Essentially his work is based on well-organised crop successions and very simple field operations. He also focused on soil restoration, regularly feeding it with specific organic manure, provided in the right season (Fukuoka, 1985). He has been a skilful atypical agronomist, a researcher leading the post-second war public plan of agricultural restoration at regional scale, at Kōchi Prefecture in Japan. Retired in his personal farm, he could follow his theory, obtaining high yields especially for rice production, in a beautiful natural frame. By replacing "struggle-for-life" in the frame of "coevolution", Masanobu transcended Darwinian's principles, and anticipated theories demonstrating that group selection is more advantageous than selfish selection for the joint maintenance of productivity and diversity (Wade, 1977; Leigh and Vermeij, 2002; Wilson and Wilson, 2008) in his practice of natural farming. The idea of "touching as less as possible, with cautious timid increasing knowledge" should be used everywhere, and not only in natural ecosystem management. Masanobu Fukuoka (Fig. 3a) died in 2008, but is still living at his farm in Japan, in Larry Korn's site: http://www.onestrawrevolution.net/One Straw Revolution/Photos Galleries/Pages/Fukuoka Farm. html\#grid. In present time, the rice fields of the family farm (Fig. 3b) are being farmed organically without synthetic chemicals.

\subsection{Allan Savory}

While mainstream science and societal thinking is that humans have many options for addressing global desertification and climate change, Savory points out that as a tool-using species we have the limited options of using technology in one of its many forms, using fire, or using technology to plant vegetation (mainly trees as widely advocated). These options have been tried for millennia but none of them could arrest global desertification, resulting in increasing drought, flooding, poverty, social breakdown, violence and mass emigration across borders (changing the political face of Europe) as well as climate change. The "missing tool" is livestock, providing animal impact and grazing that prevent oxidation from replacing biological decay over most of the seasonally wet then dry world's land area.

Because all of the many ways we have ever managed livestock, whether pastoral culture or modern agricultural science using fencing and many rotational and other grazing systems, lead to desertification, Savory developed a planning process that successfully reverses desertification, using livestock. "Holistic Planned Grazing" (Savory and Butterfield, 2016) is supported by the hypothesis that soil, soil life, plants and animals co-evolved in all terrestrial environments. In environments marked by humid and then arid periods in the year, this includes vast herds of ruminant grazing animals accompanied by large numbers of pack-hunting predators. Grazing animals move in response to predators and work the soil. The plant/ruminant/predator/soil organism system coevolved, assuring the perpetuation of a seasonal interaction. Soil, soil life, grasses and herbivores should be managed as a whole that always includes social, cultural and economic factors as well. Basing his 
method on numerous personal long-term researches (Savory and Butterfield, 1999, 2016; Butterfield et al., 2006), Savory claims that it is necessary to change society's attitude from blaming livestock for causing desertification and climate change, and recognizing that only livestock properly managed can solve this biological problem. "For all life to flourish it is essential that life, including annually dying plant material, keeps cycling. Plants, animals, humans, need to keep being born, growing, dying and decaying. Break this cycle at any point and life runs down". Savory method is also based on the observation of the importance of the hooves of grazing animals and the way that hoof action affects vegetation and soil cover. While grazing by scattered animals provide little disturbance to hardcapped soils and lay down little dead plant litter to provide soil cover, large herds trampling in concentration over short periods of time have the opposite effect. Soil surfaces are broken and litter is laid to provide soil cover, making the available rainfall more effective rather than water running off as floods or evaporating out of bare soil, and more water is retained in the soil to only leave it through plant transpiration or flowing through the soil to rivers. Used correctly, livestock produce new soil aggregates, new litter (fallen pieces of leaves), new plants (root and stolon propagules). In addition, animals in their wandering can disperse manure and grains, valorising plant sexual reproduction. A good grazing management plan recons on right pressure and timing of a relatively large number of animals, following carefully planned movement, either using fencing or on larger land areas preferred heading of the animals. Farmers should try to imitate natural associated predators and, pushing the herd, imposing a natural grazing cycle that should preserve the functionality of the whole soil-animal-plant steppe/savanna/pampas/tundra systems.

Looking at plant remains, Savory classified all environments along a simple 1-10 scale from non-brittle to very brittle environments (brittle $=$ where dead leaves and stems are so brittle that they break easily into fragments). Summarising, and looking to natural ecosystems: on one side, at the low more humid end of the brittleness scale, there were few large grazing animals (most herbivores are insects) and large predators, like jaguars or tigers, hunted singly by stealth because they had few prey; on the other hand, higher across the scale, there were brittle environments, periodically dry grasslands, where large grazing animals form a greater bulk of the herbivores. These animals had pack-hunting predators because of their greater numbers. The natural brittle ecosystems were inhabited by large numbers of herbivores in the past until most became extinct when humans, with language enabling organization and using weapons and fire, killed them off. For example, in North America there are 10 large mammal species, but in the past 500 years there were 40 more large-mammal species. Similar extinctions took place in many parts of Europe, Australia, South America and over large regions of Africa. Man reduced the number of herbivores and replaced them with fewer domesticated ruminants thus beginning the process of man-made desertification thousands of years ago.

In Humusica 1, articles 4 and 5, we classified non-brittle grasslands as earthworm Mull systems. They show biomacrostructured A horizons from anecic and endogeic earthworms (Figs. 4a and b). For these grasslands, a functional way of managing grazing animals was developed by André Voisin who first detected the flaws in rotational grazing in Europe and developed "Rational Grazing", a simply planning process based on always ensuring adequate recovery time for any plants grazed (updated in Murphy, 2010). 
Instead, the second type of grasslands may be classified as arthropod Mull (Figs. 4c-g) or Rhizo systems (in Humusica 1, articles 4 and 5; in Humusica 2, articles 13 and 18). They can also be considered as biomeso, biomicro and massive Agro Mulls (Humusica 2, article 15).

In the past time, we believed that technology in all its forms, and/or fire, and/or resting of the environment, and/or living organisms (trees and other plants, microbes, etc.) could be of help against desertification of brittle areas and climate change. Now we know (http://savory.global/allanUncensored/what-does-properly-managed-livestock-mean) that only technology can be used to develop alternatives to fossil fuel energy and to avoid continued addition of $C$ and other atmospheric pollutants contributing to climate change. Similarly, we now know that only properly managed livestock can provide the needed tool to reverse global desertification and regenerate the world's agricultural soils and vital soil life and C/water storage potential.

The "missing tool" concept is strongly related to a well-known biological functionality of the soil. No doubt that the idea that herbivorous, grassland and soil make a single unit, which should be managed as a whole, deserves at least a more attentive scientific consideration. Four photographs taken in a South-African sub-tropical pasture help to describe this assertion and show how in this dry region the structure of the soil and its functionality (e.g., porosity, energy, water content), may be strongly dependent from pedofauna living in herbivorous dung or feeding plants remains (Figs. 4c-g). An example of running soil grazing-restoration showing an effect at the level of the topsoil could be found at: https://www.facebook.com/holistisolutions/: "Vast areas of teak forest in Zimbabwe, Botswana, Zambia and Namibia are deteriorating seriously as the desertification expands. The main species Bakia plurijuga (teak) is simply not regenerating on these former wind-blown Kalahari sand soils. The soil is now very sandy and devoid of organic matter, which I think is the problem. I believe this is the usual problem of management and lack of past high ruminant animals that these forests evolved with from ancient sand dunes. We have accordingly taken over management of part of the forest using cattle as the management tool with holistic planned grazing. Here the cattle are in the forest and also grazing on one of the sites where we kept them in a mobile kraal overnight. And last picture shows the change in soil colour as organic matter begins to build once more. The light sand is the sand taken from alongside where we concentrated the cattle".

Many other similar movements are acting for rescuing the soil of our planet, founded on restoring lost organic matter and biological food web. Wanting to finalise the effort we must imitate soil life and compose "functional aggregates". Here the names of three women engaged for the future of our soil: Fransescah Munyi in Kenya (http://icrofs.dk/fileadmin/icrofs/ProGrOV/Kenya Stakeholders report Progrov Workshop 2013.p df), Elaine Ingham in the US (http://www.soilfoodweb.com/Article.html) and Christine Jones in Australia (http://renewablesoil.com/pdf/JONES-AustSoilCarbonAccScheme\%28March07\%29.pdf).

\subsection{Jeff Lowenfels}

Teaming means to gather or join in a team, a band, or a cooperative effort. This word is very appropriated for speaking of soil and it is not a hazardous consequence that Lowenfels' books, 
[Teaming with] Microbes (Lowenfeels and Lewis, 2010), Nutrients (Lowenfeels, 2013) and Fungi (Lowenfeels, 2017) are at the same time simple and efficacious. We asked Jeff Lowenfels to prepare a short overview about the concept of "soil food web". He sent 20 rules for teaming with it.

\subsubsection{Introduction}

The invention of "artificial manures" by von Liebig and others in the mid-1800s was the beginning of an agricultural revolution that continues today. Humankind finally harnessed Chemistry and forced Her to serve the ever-expanding population. Indeed, a new subset of soil was created, "agricultural soils" and the addition of these so-called artificial manures changed the way everyone viewed soils. Science and industry seemed to forget that the definition of soil includes the life in it.

By 1950 the chemical processes developed for wartime were reapplied to agricultural and mankind entered a period one company touted as "Better Living through Chemistry." Agricultural soils were tested to determine the chemical components farmers call nutrients. Missing nutrients were resupplied. Chemicals replaced organics as the major input into these soils. The microbes which are part of the very definition of soil were, for the most part, totally ignored.

Today, we are entering a period where sustainability is the watchword. We have come to recognize that we are losing soil at an alarming rate due to these relatively recent practices. At the same time we are recognizing the potential for use of microbial activity associated with the soil food web as a replacement for chemical additions to depleted agricultural soils. Actually, this is not a replacement, but a return to the natural system that predated the advent of artificial manures. The big difference is that science has made great strides. Today we can identify the very DNA of the microbes at the base of the soil food web. Once again science will advance agriculture, but it will be based on the natural system already in place and not a wholly artificial system with no baring to the very definition of soil.

\subsubsection{The soil food web}

There are myriads of food chains in the soil. Each is a line of succession created by one organism eating another and then being eaten by yet another in succession from the weakest to the ultimate survivor. Since most organisms prey off more than one type of food, these chains become interlinked and ultimately form a complex web, still depicting who eats or is eaten by whom in the soil.

This is the soil food web. Each soil environment has a different set of organisms and thus different soil food webs. At the bottom of these food web are viruses and microorganisms (algae, archaea, bacteria and fungi) (Blagodatskaya and Kuzyakov, 2013; Liu et al., 2017; Lynch et al., 2004; Puga-Freitas and Blouin, 2015). These are followed by nematodes and protozoa, arthropods, gastropods, small mammals and up the scale. In agricultural situations, humans become part of the soil food web. 
The presence of the organisms in the soil food web is responsible for many things. Soil structure is first created by the coagulation of soil particles as a result of the presence of bacterial slime (Blankinship et al., 2016; Brennan and Acosta-Martinez, 2017; Han et al., 2016; Havlicek and Mitchell, 2014; Jouquet et al., 2008; Kallenbach et al., 2016; Ranjard and Richaume, 2001; Sánchezde León et al., 2014; Schmidt et al., 2011; Spohn et al., 2016; Spohn and Giani, 2010). These particles stuck together are then woven together by fungi exploring for food. Since they are not flat cubes, pore spaces are created where smaller members of the soil food web can escape from predators, where water and air can be stored. Larger animals, worms and insect larvae burrow through these particles and create more structure.

When a member of a soil food web dies, it becomes food for other members. Nutrients are preserved in the bodies of the recyclers. And if the soil food web is a healthy one, its members will be diverse enough to keep pathogenic populations in check by producing metabolites and by outcompeting them for nutrients or space. These are just some of the benefits of a soil food web.

However, the most important benefit of a working soil food web almost always comes as a surprise to the lay person: plants use the soil food web to feed themselves (Habashi, 2016; Lynch et al., 2004; Puga-Freitas and Blouin, 2015). They expend just as much or even more photosynthetic energy producing exudates, mostly carbohydrates, but also proteins as they do producing leaves, flowers or fruits. These exudates are released into the soil, each specifically designed and manufactured by the plant to attract bacteria and fungi to the plant rhizosphere (Abbott and Murphy, 2003; Ammann, 2005; Barea et al., 2005; Bhatia, 2008; Brussard, 2012; Buckley and Schmidt, 2003; Chandler, 2006; Copley, 2000; Deutschbauer et al., 2006; Fitter et al., 2005; Fitter, 2005; Fontaine and Barot, 2005; Gewin, 2006; Högberg et al., 2001; Johansson et al., 2004; Kirchmann and Thorvaldsson, 2000; Lynch et al., 2004; Manlay et al., 2007).

In croplands of intensive agriculture, soil is inherently low in C (FAO, 2017; Hernández et al., 2014; Lam et al., 2013; Palm et al., 2014; Sommer and Bossio, 2014; Van der Wal and De Boer, 2017; Xie et al., 2017), which is needed by soil bacteria and fungi. These plant-produced exudates vastly increase the amount of easily degradable $\mathrm{C}$ in the region of the rhizosphere. Soil bacteria and fungi feed on these plant root exudates precisely because they contain so much readily available $\mathrm{C}$. The large numbers of fungi and bacteria, in turn, attract prey, specifically nematodes and protozoa who feed off the exudate-attracted bacteria and fungi. They digest the $C$ and other elements they need from their prey. The rest is released back into the rhizosphere (Burger and Jackson, 2005; Clarholm, 1989; Olof et al., 1990; Paul, 2016; Torsvik and Øvreås, 2002). Among the waste products is nitrogen, arguably the most important of the 17 known plant nutrients. It is, after all, the basic building block of amino acids, and thus of life. Nitrogen that was immobilized in a bacterium or a fungus is mineralized, initially always in the form of ammonium, $\mathrm{NH}_{4}$. If there are nitrifiers in the area, this $\mathrm{N}$ is quickly converted to nitrate, $\mathrm{NO}_{3}$. Either ionic form of nitrogen, nitrate or ammonium, is plant available nitrogen, conveniently "attracted" to and deposited in the plant rhizosphere where it is then readily available to meet the needs of the plant.

One other important factor is that some of these exudates are designed to serve as signals to specialized bacteria and fungi. In the case of bacteria, rhizobia and other nitrogen-fixing bacteria are attracted to some plants where they go through a complicated dance with the plant root hairs eventually resulting in nodules full of nitrogen-fixing bacteria. 
In the case of fungi, signalling is even more important. Over 90 percent of plants signal a specific type of fungus, a mycorrhizal fungus, and then forms a symbiotic relationship. The fungus resides in the roots and in return for the $\mathrm{C}$ provided by the plant sends out hyphae that explore the soil and return nutrients and water to the plant.

Phosphorus, in particular, a nutrient that is quickly locked up in the soil and which is never nearing peak production, is provided to plants via these relationships. In addition, nitrogen, copper and zinc, all essential nutrients, are delivered to the host plant. The two types of mycorrhizal fungi involved in agriculture, sylviculture and horticulture, endo- and ectomycorrhizal fungi, store water for use during drought situations inside the root for the former and in a sheath formed just outside the root for the matter.

As important to soil, endomycorrhizal fungi are coated with an extremely rich glycoprotein called glomalin that makes them a major source of $\mathrm{C}$ input into agricultural soils. In fact, these fungi are responsible for over $30 \%$ of $\mathrm{C}$ input into soil. As these fungi grow and branch, parts die off, depositing this much needed C. Glomalin is also very sticky and significantly adds to soil structure.

\subsubsection{The soil food web/soil/nitrogen connection}

Soils can be classified in many ways as the reader undoubtedly knows. Biological classifications are only recently being utilized. One such classification is based on the fungal versus bacterial (and archaeal) dominance in the soil sampled. Each particular plant has a preference as to the balance between these two types of organisms at the bottom of the soil food web (Lowenfels and Wayne, 2010; Soil Health, 2016; Malik et al., 2016).

It has long been known that bacterial colonies produce a slimy substance that allows them to stick to each other and to avoid predators (a perfect example of this slime is the coating that forms on teeth overnight). This very slime is the basis of soil structure wherein some particles of soil stick to each other because of its presence. It is alkaline in nature, meaning it imparts a pH above 7 and soils that are dominated by bacteria have a $\mathrm{pH}$ above 7 . Note that at this $\mathrm{pH}$ nitrifying microorganisms thrive, hence the rapid transformation of ammonium $\left(\mathrm{NH}_{4}\right)$ to nitrate $\left(\mathrm{NO}_{3}\right)$ in soils that are dominated by bacteria.

Fungi, on the other hand, produce organic acids and soils that are dominated by fungi are acidic. They have a $\mathrm{pH}$ below 7 . The lower the $\mathrm{pH}$, the lower the numbers of nitrogen-fixing bacteria are likely to be found. Little if any of the ammonium produced by the recycling of bacteria and fungi is converted into the other form of plant available nitrogen.

Some plants prefer nitrogen in ammonium form and others in nitrate form. Thus, it is necessary to develop an easy method of identifying which of the two forms of nitrogen a crop or plant prefers (Boudsocq et al., 2012). Even if bacterial numbers in soils can vary quickly (e.g. depending on seasonality or climate events, measured with both fumigation-extraction or molecular qPCR methods), in the most general sense, bacterial numbers in soil seem to remain the same (Wieland et al., 2001; Taylor et al., 2002; Lowenfels and Wayne, 2010). The ratio to fungi, however, changes (Malik et al., 2016; Morriën, 2016; Sechi et al., 2017). As it turns out, in the initial and early stages of successional environments, there are almost only bacteria in the sands and early soils. As 
plants begin to develop and more complex waste material accumulates, fungi move in. By the time one is testing soils at the other end of the successional scale, old-growth forests, the fungal mass far dominates over the bacterial one. Each organism has its place along this line of succession.

As a general rule (Hodge et al., 2000; Masclaux-Daubresse et al., 2010; Pugesgaard et al., 2015; Rahmani et al., 2004), plants that are only in the ground for a season seem to prefer their nitrogen in nitrate form. This would include most agricultural crops as well as annual fruits. And, again, generally, plants that are in the ground for more than a season tend to prefer ammonium. The fungal network provides the appropriate acidic environment, perhaps enhanced by plant exudation. This would include trees and shrubs as well as perennials.

\subsubsection{Modern agricultural practices}

Modern agricultural practices are an anathema to the soil food web. Physical disturbance of soil via rototilling and other disking practices rip up mycorrhizal networks and displace spores. Larger members of the soil food web community are often killed while others are completely displaced.

While some microbes feed on chemical fertilizers, many do not survive them. Worms avoid many of these fertilizers. Soil food webs are destroyed, thinned or altered and they cease to work the way they are supposed to, impacting soil structure and providing an opportunity for opportunistic members of the web as well as weeds.

In addition, plants themselves react in curious ways to these techniques. They don't need to expend their energy for producing and maintaining relationships with fungi and bacteria if they get their nutrients for free. Too much phosphorus and mycorrhizae don't form. Natural nitrogen fixation is reduced. Without natural ways to feed themselves, plants become dependent on humans. And, since the natural defences have been disrupted, human caretakers have to step in to provide these as well as nutrients. The unintended consequences of practices that disturb and alter the soil food web are many and have been highlighted for years.

Soil management, then, should be concerned with preserving and promoting cropappropriate soil food webs. Zero-tillage, for example, should be an immediate goal as should the reduction and elimination of pesticides and synthetic nutrients. The use of techniques to promote the appropriate soil food webs should follow. In fact, the set of rules for working with the soil food web are short and simple:

Rule 1: Some plants prefer the kind of nitrogen provided by soils dominated by fungi; others prefer the nitrogen provided by soils dominated by bacteria.

Rule 2: Vegetables, annuals and grasses prefer their nitrogen in nitrate form and therefore do best in bacterial-dominated soils.

Rule 3: Perennials, shrubs, and trees prefer their nitrogen in ammonium form and do best in fungal-dominated soils.

Rule 4: Compost can be used to inoculate soil and to support the formation of a diverse, selfstabilizing microbial soil population which by itself supports a stable food web (Fritz et al., 2012). 
Rule 5: Adding compost to the surface of the soil will inoculate the soil with the same soil food web in the compost.

Rule 6: Brown organic materials support fungi while green ones support bacteria.

Rule 7: Fresh, green mulches tend to support bacterial populations; aged, brown mulches support fungal growth.

Rule 8: Mulch laid on the surface tends to support fungi while mulch worked into the soil tends to support bacteria.

Rule 9: Wetting and pulverizing mulch thoroughly speeds up bacterial colonization.

Rule 10: Coarse, drier mulches support fungal activity.

Rule 11: Sugars help bacteria multiplying and growing while kelp, humic and fulvic acids and phosphate rock dusts help fungi grow.

Rule 12: Depending on the compost and the nutrients added, you can make soil and water mixes that are fungal-dominated, bacterial-dominated or an even ratio of both.

Rule 13: Compost teas are very sensitive to chlorine and preservatives in brewing water and ingredients.

Rule 14: Applications of synthetic fertilizers kill off or alter populations of most or all of the soil food web microbes.

Rule 15: Stay away high NPK numbers which cause plants to shut off natural processes.

Rule 16: Immediately follow any chemical spraying or soil drenching with an application of compost tea or extract, mulch and or compost to reignite the soil food web.

Rule 17: The roots of conifers as well as of nutrient-sparing hardwood trees, including birch, oak, beech, and hickory, form mycorrhizae with ectomycorrhizal fungi and these should be applied at the time of seeding or planting.

Rule 18: Shrubs and nutrient-exacting hardwood trees form mycorrhizae with endomycorrhizal fungi.

Rule 19: Rototilling and excessive soil turning destroys or severely damages the soil food web. The least amount of disturbance is all that should be used.

Rule 20: Always mix the appropriate endomycorrhizal fungi with the seeds of annuals and vegetables at planting time or apply them to roots at transplanting time.

In essence, fostering a healthy soil food web only requires acknowledgement that agricultural soils should be teaming with life, a rich diverse population of soil animals and microorganisms (algae, fungi, bacteria, etc.), so that plants can provide for themselves. The application of human genius to improve the ability to provide food to the world's population should be confined to improving what Nature has developed instead of replacing it, as modern agricultural techniques have done. 


\section{Anthropogenic soil structure dynamics}

Soil functionality is related to soil structure. Humans selected a particular humus system for the practice of agriculture (Humusica 2, article 18). Müller (1879), a Danish forest engineer, called it "Muld", becoming "Mull" in later publications. In equatorial and temperate rainy regions, the structure of these Mull humus systems is built by large anecic and endogeic earthworms. In equivalent subtropical or continental periodically dry warm/cold regions, Mull systems are made by arthropods (termites, ants, insect larvae) and roots. Mull systems are common in grasslands, steppes, savannas or tundras, mostly assigned to pasture. They are also common in temperate deciduous forests and in equatorial rain forests. The relationship between earthworms and arthropods is still under investigation (Beare et al., 1992; Wickenbrock and Heisler, 1997; Wise et al., 1999; Scheu, 2002; Salmon, 2004; Bedano et al., 2006; Aira et al., 2008; Monroy et al., 2011). In dry tropical and subtropical areas, arthropods dominate (Whitford, 2000; Brown et al., 2000; Berg and Laskowski, 2006). We created a specific Rhizo humus system for classifying humipedons built by roots (Humusica 2 , article 13). Rhizo systems are often complementary to Mull systems in grazing areas dominated by large earthworms or arthropods. Root exudates are an important source of energy for soil microorganisms (Rovira, 1969) and are even considered in climate change studies (Keiluweit et al., 2015).

A large part of crop lands result from natural Mull systems more or less transformed by Man. A detailed description of the soil structure of agricultural fields is given in Humusica 2, article 15. For better understanding the correlation between soil structure and functioning, we asked the intervention of some experts, such as Marcel Bouché (France), Debasish Saha and Surinder Singh Kukal (India, USA).

With the agreement of the former author, in Section 4.1. we translated in English the core pages (149-168) of his recent book (Bouché, 2014). In this book, Marcel Bouché claims that humans and earthworms occupy the same landscape for nutritional reasons. Continuously re-elaborating the soil structure, eating their own ripen droppings and adding new organic matter (OM) and living microorganisms to them, earthworms may indefinitely preserve the fertility of agricultural soils exploited by Man. Earthworms and plants recharge the soil as it was an OM battery.

Debasish Saha and Surinder Singh Kukal measured the quantity and dimensions of water stable soil aggregates with a method (Yoder, 1936) that is comparable to the distinction of macro ( $\geq 4$ $\mathrm{mm})$, meso and micro ( $\leq 2 \mathrm{~mm}$ ) aggregates that Humipedon specialists make by the naked eyes in the field (Humusica 1, articles 4 and 5; Humusica 2, article 15). An updated version of Yoder's method (Verhulst et al., 2013) is freely downloadable at http://repository.cimmyt.org/xmlui/handle/10883/3389 and we strongly recommend to use it for investigations involving soil structure. It is well known that soil aggregates are a crucial key for understanding soil functioning (Don et al., 2007; Wasak and Drewnik, 2015). Debasish Saha and Surinder Singh Kukal accepted to summarize their results in Section 4.2. Size and quantity of soil aggregates are strongly related to the content of Soil Organic Carbon (SOC). Fundamentally, these authors established that the higher the size of stable biological aggregates, the higher the content in 
SOC. The analysed data allowed them to arrange with an increasing SOC content the following uses of the soil: eroded < cultivated < forest < grassland. We know that the number of anecic earthworms is strongly related to each unit reported in the trend and is lower in cultivated soils than in forests and grasslands (Paoletti, 1999).

\subsection{Of worms and men, a tribute to Charles Darwin (from Bouché, 2014)}

Charles Darwin departed Davenport on 27 December 1831 aboard the HMS Beagle for a trip around the Earth which was not completed until October 2, 1836. But as soon as he returned to England after this long journey, Darwin devoted himself to the writing of a communication, presented in November 1837, which describes the formation of vegetable earth under the digestive action of earthworms from his garden. By ingesting, crushing and digesting vegetable products, for the most part dead, and by intimately mixing them with soil minerals, earthworms perform an intestinal process which results in the production of organic-mineral crumbs which constitute, by their accumulation, a soil stratum. Darwin remarks that this stratum, called vegetable earth, would be better called animal earth. The importance of it measured by Charles Darwin, about $30 \mathrm{t}$ casts per hectare deposited by earthworms on the surface of the soil each year, remains an order of magnitude valid a century and a half later. Only change, but prominent, this natural tillage has ceased to be in the most fertile lands under the deleterious effects of conventional farming practices.

Anecic worms, dominant in the most fertile land, actively seek their organic food on the surface of the soil, mostly litter, leaving their tails engaged in the orifices of their galleries opening out into the open air. The litter mainly consists of debris from dead plants, especially leaves, stuffed with microorganisms. Earthworms also ingest algae on the soil and, in the soil, organic debris and roots, in principle dead. In laboratory conditions, aberrant as is often the case, it is suspected that the ingestion of tender live roots is possible. Finally, the ingested food includes a "lombrimix" from fermented earthworm faeces. A century later, we succeeded in measuring the mass of organic matter ingested then triturated. It is enough to follow the transit rate of wheat bran in the digestive tract to calculate the amount of matter passing through it and to discover that the elucubrations relating to this quantity, based on hypotheses then on laboratory measurements, have always been wrong. The measure thus obtained, extrapolated over the year thanks to an index of activity, gives us $221 \mathrm{~kg}$ of soil transiting in $1 \mathrm{~kg}$ of anecic worms (living mass) per year. We will retain here an order of magnitude of $270 \mathrm{t}$ of dry ingested food per tonne of anecic or epianecic worms per year. This represents annually $1.8 \mathrm{~kg}$ of dry ingested food per gram of earthworm in dry mass!

There are large differences between the ecological categories of earthworms. The organicmineral fraction ingested, consisting of minerals to which a strongly decayed organic matter is closely linked, is very low in the epigeics ( $40 \%$ of ingested food), the largest $(80 \%)$ in the anecics which ingest again the "lombrimix" from their faeces, and very important (90\%) among the endogeics which consume mainly soil. In addition, "free" plant debris not linked to minerals, respectively 60, 20 and $10 \%$ for the three abovementioned ecological earthworm categories, make it possible to observe in detail what is consumed by every species cohabiting in the same meadow. While every species can 
more or less consume the food of other species cohabiting with it, each of them is more effective in selecting its preferred foods from the diversity of dead plant products.

Grinding by buccal mastication allows the direct ingestion of plant debris and, via the oesophagus, their passage to the jabot-gizzard assemblage. This mastication depends on the power of the peribuccal musculature, very developed in the anecics, and this more so as these animals are large. Thus, in the nocturnal silence, I (Marcel Bouché) could hear the giant worm of Montpellier Scherotheca monspessulensis crushing dead leaves from holm oak. The food collected on the surface of the soil finally arrives at the burrow entrance and generally penetrates the burrow except when the diameter of the burrow is clearly lower than the food drawn to its entrance. There are then waste deposits on the surface of the soil near the entrance, which can thus be decorated with a bunch of plant debris (e.g., pine needles, large resistant leaves), thus forming superficial edifices, the so-called earthworm "middens".

I was fortunate to participate in a study conducted by François Toutain, from the CNRS of Nancy, on changes in the vertical distribution of soil elements induced by the anecic earthworm Nicodrilus velox, commonly almost $50 \mathrm{~cm}$ long. Surprisingly, once their food bolus was reconstituted, it appeared that they ingested mainly old earthworm casts (63.6\%), then superficial (1\%), average (12.7\%) and deep (3.2\%) layers of the soil, and only $1.4 \%$ litter. The ingested organic matter comes mainly from dead leaves (76.1\%), then from fermented old casts $(15.9 \%)$, and finally from the soil in an amount decreasing from surface to depth $(5.6 \%, 1.9 \%$ and $0.6 \%)$. Thus, this anecic massively incorporates litter into the soil, but also uses organic matter in the "lombrimix" of old droppings, thus recycling them in a new digestive run. It also incorporates the soil, especially mineral, with this organic assemblage. At the beginning of the gut transit, water and abundant intestinal mucus stimulate the intestinal microflora and lubricate the passage of the food bolus in the digestive tract. Digestion is therefore carried out essentially by grinding, mixing, and controlling the conditions of humidity and neutrality of the food bolus, and by enzymatic catalysis. The enzymes involved originate from salivary and intestinal excretions of the worms and from the intestinal microflora. Let us emphasize here an important digestive property. The leaves of trees, especially of beech, become brown when dead. This dark colour is due to the formation of brown bodies which result from the contact in the cells of the phenolic compounds of the vacuoles with the proteins of the cytoplasm. These brown bodies, which are rich in nitrogen, are difficult to degrade and in temperate climates there are only two types of organisms capable of transforming brown pigments: white rot fungi and anecic earthworms. The dissolution of these brown bodies, during earthworm digestion, is observed by transmission electron microscopy and results from the action of specific enzymes, polyphenoloxidases, which are active only in the intestinal lumen of earthworms and at the growing ends of white rot mycelia.

On the other hand, many materials, especially mineral (clay, sand, silt particles) but also organic, are not digestible, and are ultimately rejected in the external environment by defecation in the form of a particular organic-mineral mixture, the "lombrimix", closely mingling all these constituents, in particular forming stable clay-mineral complexes. It should be remembered that, on average, "lombrimix" produces on average only $270 \mathrm{t}$ per hectare of dry matter per year per $1 \mathrm{t}$ live animals. We know, from measurements directly carried out in the field with double marking, what is excreted in the form of mucus and products of degradation of the metabolism. The assimilated nitrogen is totally excreted as ammonia in the urine and as carbonaceous compounds in the mucus. 
It is therefore not volatilised. On the other hand, we found that only $55 \%$ of the $\mathrm{C}$ dissipated during digestion is assimilated, in the form of "energetic" molecules such as glucose and fructose resulting from the decomposition of cellulose, and that the remaining 45\% "disappear" during the intestinal transit. In fact, the $\mathrm{C}$ of the dead organic matter has been largely "burnt" and evacuated, most probably in the form of $\mathrm{C}$ dioxide. In the end, the $\mathrm{C}$ of the organic matter follows, from the ingestion, three pathways:

- C dioxide from digestion (about 22.5\%);

- earthworm assimilation (approximately 27.5\%) followed by respiratory dissipation;

- defecation (undecayed organic matter mixed with minerals), $50 \%$.

For nitrogen, the scheme is much simpler and well proven:

- assimilation (16.5\%);

- defecation (83.5\%) with, in part, ammonia formation.

As a result, the ratio of $\mathrm{C}$ to nitrogen $(\mathrm{C} / \mathrm{N})$ in our baseline study decreases from 31 in food to 20 in the faeces. This underlines the importance of the internal recycling of nitrogen in soils. It is a cycle where plants play their role in assimilating nitrogen from earthworm excreta and microbial decomposition, and restoring this chemical element to earthworms and micro-organisms essentially in the form of dead organic matter. $\mathrm{C}$ follows roughly the same pathway. In its cycle, the nongaseous mass ingested is approximately 4.5 times greater than that of nitrogen, or $10 \mathrm{t}$ of $\mathrm{C}$ recycled per hectare per year. All the ingested organic matter cannot be digested because there are plant tissues that resist digestion. These indigestible organic materials, mixed with minerals (clay, silt and fine sand particles), are expelled in faeces. These droppings constitute a paste where bacteria and fungi thrive, slowly degrade organic substrates and, after incubation in the soil, refine a real "cheese", called "lombrimix".

Approximately $50 \%$ (about $2.7 \mathrm{t}$ ) of "lombrimix" deposited in the soil or in the form of casts will be ingested again after a microbial fermentation which transforms the qualities of the organic matter, in the manner of cheese ripening. This maturation decomposes $14.7 \%$ of the $C$ initially ingested ( $147 \mathrm{~g}$ per $\left.\mathrm{m}^{2}\right)$, so that about $1.3 \mathrm{t}$ per hectare $\left(130 \mathrm{~g} \mathrm{per} \mathrm{m}^{2}\right)$ of $\mathrm{C}$ that has passed through the gastrointestinal tract will be recycled each year after this post-anal maturation. The remaining $50 \%$ of the "lombrimix" will, after a slow evolution, be transformed into organic-mineral aggregates slowly reincorporated into the soil layers where other animals of modest size (e.g., springtails, potworms) are feeding, as observed on soil slides under the microscope. Simultaneously, intestinal mixing disperses microbial germs on new food substrates. During gut transit there is an agitation similar to that performed by brewers of beer. However, it is a much more diverse microflora than that of brewer's yeast and an infinitely more varied substrate than malts from breweries. Almost half of the ingested organic matter could not be digested in the few hours of intestinal transit. This indigestible matter, after defecation, nourishes the microorganisms to which it is closely intertwined in the "lombrimix", in which there is then an explosion of life. In a few days the microbial respiration increases by at least ten times then gradually decreases in a few weeks. This respiration demonstrates the intensity of microbial functions. One of these functions is observable under the electron microscope: it is the production of "glue", in fact microbial mucus, which agglomerates the moulded elements in droppings which become, with this glue, solid in the form of mini-bricks. In soil science this property is called structural stability. Microorganisms use a non-negligible part of the 
organic matter that has resisted digestion in the earthworm intestine. To do this, they excrete enzymes that release, from this organic matter, small molecules such as amino acids. Then, after use of these small molecules, microorganisms reject even simpler constituents, such as nitrogen in the form of ammonia, directly assimilable by plants. Consequently, it is not surprising that plant roots coat and invade earthworm aggregates to benefit from assimilable molecules released by microbial activity.

\subsection{Land cover influence on soil aggregate stability and $\mathrm{C}$ retention}

Aggregate stability is an important soil quality parameter which refers to the resistance of soil aggregates from disintegration under disruptive forces such as tillage, water, and wind erosion. Wet aggregate stability is associated with soils ability to retain its structural integrity under the erosive forces of falling raindrops. SOM and biological activity play a key role in aggregate formation. Decomposing SOM, fungal hyphae, root exudation, and biological secretions by soil organisms help to bind soil particles to form aggregates. The occluded $\mathrm{C}$ within stable aggregates is protected from loss due to water erosion as well as microbial decomposition. Thus, soil management practices that promote better soil aggregate stability may facilitate long-term $\mathrm{C}$ sequestration in soil to mitigate increasing atmospheric $\mathrm{C}$ dioxide concentration and global warming (Lal and Bruce, 1999).

Furthermore, well-aggregated soil promotes better soil physical environment to facilitate water infiltration, aeration status, root growth, nutrient cycling, and plant growth. The size distribution of water stable aggregates (WSA) is also influenced by management practices and may influence the quantity and durability of sequestered $C$. The higher proportion of micro-aggregates $(<0.25 \mathrm{~mm})$ in conventionally cultivated lands than in forest and grassland soils indicates mechanical breakdown of macro-aggregates (>0.25 mm) by tillage and subsequent loss of soil C (Gajic et al., 2006; Saha et al., 2011). Thus, changes in aggregate size distribution and stability may serve as indicators of recovery or degradation of soil.

We hypothesize that aggregate size distribution will influence $\mathrm{SOC}$ concentration within aggregates as influenced by different land uses. We further hypothesize that soils with a greater proportion of water stable macro-aggregates $(>0.25 \mathrm{~mm})$ will have higher SOC stock. In order to test our hypotheses, we selected eroded, cultivated, grassland, and forest land areas in a mixed watershed located in the foothills of the lower Shiwaliks in northwest India. Three locations were selected within each land area on the basis of the criterion of similar soil texture and topography. The WSA size distribution was measured by the wet sieving technique (Yoder, 1936) using a nest of sieves of sizes $2.0,0.25$, and $0.1 \mathrm{~mm}$. A $50 \mathrm{~g}$ sample of $4-8 \mathrm{~mm}$ sized dry-sieved aggregates was placed in the top-most sieve $(2.0 \mathrm{~mm})$ of the nest. The water level in the container was adjusted so as to just touch the base of this sieve. The aggregates were allowed to saturate by capillary action of water. After saturating the soil for $10 \mathrm{~min}$, the sieve rack along with pre-saturated soil sample in the top-most sieve was shaken under water for $30 \mathrm{~min}$ at the rate of 30 vertical oscillations per minute. The amount of soil retained on each sieve was dried at $105^{\circ} \mathrm{C}$ for $24 \mathrm{~h}$ and expressed as percentage of aggregates for a particular size class. The SOC was determined by Walkley and Black's rapid titration method. The SOC stock was calculated for each land use from SOC content, soil bulk density, and depth of soil layer. 


\subsubsection{SOC content as influenced by WSA size distribution}

The SOC content decreased with decrease in WSA size (Fig. 5). The SOC in bigger macroaggregates ( $>2 \mathrm{~mm}$ ) greatly varied among different land areas and followed the order: grassland > forest $>$ cultivated > eroded soils. The WSA $>2 \mathrm{~mm}$ from the eroded soils had 54,49 , and $27 \%$ lower SOC than the grassland, forest, and cultivated soils, respectively. However, these differences became narrow with further decrease in the size of WSA. Macro-aggregates act as primary storage sites for SOC and any change in SOC due to change in land use or soil erosion is more pronounced in macroaggregates (Jastrow et al., 1998; Saha et al., 2011; Scott et al., 2014).

\subsubsection{Water stable macro-aggregates promotes greater SOC storage}

A greater proportion of water-stable macro-aggregates resulted in greater SOC stocks in grassland soils (Fig. 5 and Saha et al., 2011). The SOC stock in the $0-15 \mathrm{~cm}$ soil layer was $88 \%$ higher in grassland soils than in eroded soils ( $30 \mathrm{vs} 4 \mathrm{Mg} \mathrm{ha}^{-1}$, Fig. 6). We found a positive correlation between WSA $>0.25 \mathrm{~mm}$ and SOC stock $\left(R^{2}=0.58, n=24, p \leq 0.05\right.$; Fig. 7).

Our results indicate that an increasing proportion of water stable macro-aggregates can sequester more $\mathrm{C}$, with additional interactions with climate and vegetation factors. Stable aggregates (especially macro-aggregates, Scott et al., 2014) can protect SOC within aggregates from erosional losses. This is important in the degraded Shiwaliks region of India with low soil organic matter content and greater susceptibility to water erosion.

It has also been shown that the wet sieving method is a viable, rapid, and cheap technique to measure water stability and size distribution of soil aggregates, which is further related to soil C sequestration, and soil physical environment.

\section{Is conservation agriculture economically sustainable? A case study in the Po Valley, Italy}

We can even find a beautiful theoretical issue but if, in the end, we cannot get a financial support for its realisation, it would become a bad issue. We tried to evaluate the costs of soil restoration in a typical European agricultural context, a temperate mesophilic plain, with Mull humipedon on Cambisol, or Luvisol, and a very common cycle of production. Indirect costs and advantages were not established, preferring to estimate direct costs and gains considered by a farmer for taking a decision and choose between conservative or conventional agriculture in presentday conditions.

\subsection{Conservation agriculture}


Conservation agriculture can be defined as a "concept for resource-saving agricultural crop production that strives to attain both acceptable profits and high and sustained production levels while conserving the environment at the same time" (Food and Agriculture Organization (FAO), 2007).

In very short, conservative agriculture claims three principles (Brenna et al., 2013; Lal et al., 2015): 1) practice a minimum mechanical soil disturbance (no or minimum tillage, without disturbing the succession of natural soil horizons); 2) create a permanent organic soil cover or a structured organic-mineral layer, offering protection from soil erosion; 3 ) practice crop rotation with more than two species. Conservation agriculture techniques are spreading rapidly worldwide. The latest available estimates show that $11 \%$ of field cropland corresponding to $155,000,000$ ha is managed by conservative agricultural techniques using no tillage or minimum tillage. In the last 10 years, conservative agriculture cropland has expanded at an average rate of more than $8.3 \mathrm{M}$ ha per year and since 2008/2009 at the rate of some $10 \mathrm{M}$ ha per year (Kassam et al., 2015). In the 1990's conservation agriculture spread further with public support given positive environmental effects on $\mathrm{C}$ sequestration and biodiversity, reductions in fuel consumption and soil erosion, improvements in the regulation of hydrological and nutrient cycles.

The distribution of conservative agriculture is concentrated mainly in North and South America, which share $76 \%$ of total conservation agriculture in the world, in Australia-New Zealand for $12 \%$, and is increasing in interest in Europe and Africa. In Italy, this technique was applied on 80,000 ha in 2008 and increased more than four times raising, 380,000 ha in 2013 (Brenna et al., 2013; Kassam et al., 2015) corresponding to $3 \%$ of the agricultural surface.

\subsection{Economic estimations, with and without public support}

This study performed a comparison between the average annual income per hectare of arable land conventionally farmed, with minimum tillage (MT) and no tillage (NT), with and without public support.

The costs of the different techniques were collected directly through a 5-yr pilot test conducted in an Italian experimental farm located in Ceregnano (Rovigo) in the eastern Po Valley. The analysis considered the direct costs of production in a rotation of corn, soy, wheat and cover crops, the latter being necessary for MT and NT, assuming that all tillage was made by contractors and that there were no irrigation costs. The sale price of the products was quantified according to optimistic and realistic scenarios. In the optimistic scenario, sale prices were determined by averaging for each crop historical 2004-2016 monthly price series during harvest period (Fig. 8). The realistic scenario used a lower price level as indicated by outlook trends (OECD/Food and Agriculture Organization of the United Nations, 2014).

In the example below, we report the costs for corn (Table 2), grouping the other estimation on a table while calculating gross margins (Table 3 ). 
The registered cost of corn production is lower for NT (1,480 $€ /$ ha) compared to $1,600 € /$ ha for MT and $1715 € /$ ha for conventional farming.

The minimum yields required to cover direct costs for corn is given by the ratio total cost/average price $=1715 / 176=9.74 \mathrm{t} /$ ha for conventional, $9.09 \mathrm{t} / \mathrm{ha}$ for MT and $8.41 \mathrm{t} / \mathrm{ha}$ for NT (Fig. 9). These values are higher than the average yields obtained in experimental fields in Ceregnano for MT and NT, i.e. 0.77 and $2.25 \mathrm{t} / \mathrm{ha}$, respectively while they are lower for conventional farming with $0.75 \mathrm{t} / \mathrm{ha}$.

The same process of estimation was repeated for wheat and soybean. Results are summarised in Table 3. In the optimistic scenario, the gross margin for corn is positive only for conventional (130.9 $€ / h a)$, negative for MT (-75) and NT (-416.5); for wheat, the gross margin is highly positive and greater for MT ( $359 € /$ ha) than for NT ( $335 € /$ ha) and conventional farming (299 $€ /$ ha); for soybean, the gross margin is higher for conventional farming (691 $€ /$ ha), lower with NT (474 €/ha) and intermediate with MT (640€/ha).

After spring-summer crops, cover crops must be used to ensure soil cover. An average cost of $210 € /$ ha was estimated adding seeding $(130 €)$ and chemical weeding $(80 €)$ costs at the end of the cycle.

In order to quantify the average profitability of conservation agriculture, a real five-year crop rotation of wheat, corn, soybean, corn and corn managed by conventional, MT and NT farming was predisposed. Following the requests of the rural development plan of Veneto Region, with MT and NT the crop succession plan must follow wheat, corn, soybean, wheat and corn; in addition, cover crops are mandatory after the spring-summer crops of corn and soybean (Table 4).

With conventional rotation, gross margin is positive and higher with soybean (692 $€ /$ ha) and lower with corn (131 €/ha). The average annual margin is equal to $277 € /$ ha.

With minimum tillage, gross margin is negative $(-345.33 € / \mathrm{ha})$ in the years cultivated with corn and cover crops. Without public subsidies, the average annually gross margin is equal to +91.7 $€ /$ ha. Gross margin becomes $417 € /$ ha with a public subsidy ( $325 € /$ ha) according to Veneto Rural Development plan. In the case of NT rotation, gross margin continues to be negative with corn (-607 $€ /$ ha). The annual average gross margin for five years of rotation with all crops is negative $(-56 € / \mathrm{ha})$, but becomes positive ( $488 € /$ ha) thanks to a public subsidy of $544 € / \mathrm{ha} / \mathrm{y}$.

Finally, in the optimistic scenario and thanks to public subsidies, NT cultivation gives the best profitability with $488 € / \mathrm{ha} / \mathrm{y}$, against $211.6 € / \mathrm{ha} / \mathrm{y}$ for conventional farming. MT gives an average revenue of $416.7 € /$ ha, which is $139.9 € /$ ha higher than for conventional farming. Without public support, conventional farming is profitable with $276.8 € /$ ha, MT less profitable with $91.7 € /$ ha, while NT is negative $(-55.6 € / \mathrm{ha})$.

In the realistic scenario, the OECD-FAO outlook 2014 forecasting a decreasing trend of commodities, medium time prices were lower for corn (150 €/t), wheat (160) and for soybean (300). Outputs for the realistic scenario were calculated utilizing the same costs and yields used for the optimistic one. Compared to conventional farming, with a positive gross margin ( $44.9 € / \mathrm{ha}$ ), conservation agriculture was not competitive without public subsidies. MT and NT gave negative gross margins, -131.4 and $-251.5 € /$ ha, respectively. Subsidies from the Veneto Region invert the 
situation, rendering NT and MT profitable, with gross margins equal to 292.5 and $193.6 € /$ ha, respectively (Fig. 10).

Conservation agriculture benefits of public support because it aims to conserve and improve natural resources such as soil, water and biodiversity. MT and NT lead to an increase in SOC, up to the achievement of a "saturation point", which can take place at different times over which the soil reaches its storage capacity. Conservation agriculture can also mitigate global warming, which has a cost that can be compared with the losses we measured for conventional agriculture (Brenna et al., 2013; Stockmann et al., 2013).

\subsection{Timing and comparison with costs of other storage techniques}

Knowing initial (current level) and final (at saturation) SOC contents and potential average annual SOC addition, we can calculate the time during which soil may act as a sink of $\mathrm{C}$.

Typically, arable soils contain 1-3\% of OC (Stockmann et al., 2013). In the eastern part of the Po Valley, the Soil Service of the Veneto Region measured an average 1\% of SOC (ARPAV, 2010) in the first $30 \mathrm{~cm}$ of cultivated regional soils. This relatively low average is explained by a strong process of organic matter mineralization caused by intensive farming techniques, especially in the presence of soils with coarse texture under temperate sub-Mediterranean climate. The maximum content of organic $\mathrm{C}$ storable in agricultural soils is variable and depends on soil composition and structure. In European croplands, it runs from 1.4\% (Brenna et al., 2013) to 2.4\% (Smith et al., 2005).

Our experiments conducted during 5 years in Ceregnano showed an annual SOC storage capacity of about $2.1 \mathrm{t} / \mathrm{ha} / \mathrm{y}$ in MT plots and $3.2 \mathrm{t} / \mathrm{ha} / \mathrm{y}$ in NT ones. We linearly applied these experimental values of annual storage (Figs. 11a and b) to SOC, bringing it from 1\% (measured: 56 $\mathrm{t} / \mathrm{ha}$ ) to $1.4 \%$ (point of saturation estimated at $78.4 \mathrm{t} / \mathrm{ha}$, scenario 1 ) and from 1 to $2.4 \%$ (saturation at $134 \mathrm{t} /$ ha, scenario 2). It results that soils will saturate in 7 or 11 years for scenario 1 and in 24 or 37 years for scenario 2, in NT and MT scenarios, respectively (Table 5).

In French croplands equivalent to Po Plain soil types, comparable initial and final contents in SOC have been measured (Mustin, 1987; Agriculteurs Composteurs de France, 2015). An empirical calculation (abacus) proposed by J.R. Mercier in Mustin (1987), based on a standard coefficient of mineralisation of $1.67 \%$ (quantity of OM mineralized in a year), lists an amount of about $2 \mathrm{t} / \mathrm{ha} / \mathrm{y}$ of equivalent equivalent-humus (corresponding to $4 \mathrm{t} / \mathrm{ha} / \mathrm{y}$ of anhydrous manure with a coefficient of humification of 0.5 ) to be distributed on the soil for increasing SOC by 1 to $2 \%$ in 20 years. Compared to our experiment, the added equivalent-humus is the quantity "dissipated" (becoming $\mathrm{CO}_{2}$ ) with conventional tillage in comparison to minimum tillage. Alfieri (2013) reports a similar linear trend during a 10-year experiment in the western part of Po Plain. Before reaching a saturation plateau, a linear relationship was calculated by Hua et al. (2014) between annual C input and SOC sequestration rate in conventionally cultivated Vertisols in China. The starting SOC content was about $0.5 \%$. Using NPK fertilizer plus wheat straw ( $5 \mathrm{t} / \mathrm{ha} / \mathrm{y})$ or pig manure $(7.8 \mathrm{t} / \mathrm{ha} / \mathrm{y})$ these authors reached a saturation point at $1.4 \%$ of SOC in 29 years; in the same period, using a high amount of cattle manure (12 t/ha/y), SOC reached nearly $2 \%$. Total mean annual C inputs of wheat straw, pig and cattle 
manures were $3.71,4.68$ and $6.56 \mathrm{t} / \mathrm{ha} / \mathrm{y}$ and $\mathrm{C}$ sequestration efficiencies were 17,11 and $17 \%$, respectively.

The current support of the public Rural Development Plan for conservation agriculture amounts at $530 € /$ ha/y in the case of NT and $325 € /$ ha/y for MT (Table 5). If we suppose that all the financial public support is given for paying SOC storage, the cost to reach saturation capacity in 7 or 11 years (scenario 1 , NT or MT) is $530 * 7=3710 €$ or $325 * 11=3467 €$, which means a cost of $155-165$ $€$ for each stored tonne of SOC.

For scenario 2, the storing time would be longer (24 years with NT, 37 with MT).

At most, we can use the Po Plain soil as a $\mathrm{C}$ sink for 37 years. In a warming climate perspective, it is better to find an alternative to oil energy before the end of this short "soil-buffer" period. A single tonne of $\mathrm{C}$ corresponds to $3,664,346 \mathrm{t}$ of $\mathrm{CO}_{2}$. The cost per ton of $\mathrm{CO}_{2}$ would be $42-$ $45 €$, which is higher than for $C$ stored by forest management, but lower than that set in woody manufactures, urban afforestation and captured $\mathrm{C}$ storage (Table 6).

The Soil Service of the Veneto Region published the amount of cultivated area with a SOC content $<1 \%(530,871$ of 802,000 ha, i.e. $66 \%$ of total agricultural land):

http://www.arpa.veneto.it/arpavinforma/indicatoriambientali/indicatori ambientali/geosfera/qualita-dei-suoli/contenuto-di-carbonio-organico-nellostratosuperficiale-di-suolo/view. Just for curiosity and using the same linear formula of preceding scenarios (increase of $2.1 \mathrm{t} / \mathrm{y}$ with MT and $3.2 \mathrm{t} / \mathrm{y}$ with NT), we calculated how much SOC could be annually stored in the first $30 \mathrm{~cm}$ of soil (starting point: $\mathrm{SOC}<1 \%$ ) at regional scale. We found $1,114,829$ tonnes/year of SOC with MT and 1,698,787 tonnes/year with NT. These capacities of storage correspond to about 13 and $20 \%$ of the total emission of the Veneto Region in 2010 $\left(31,100,000 \mathrm{t}\right.$ of $\left.\mathrm{CO}_{2}\right)$. This amount could compensate the production of regional electric energy, or industrial or domestic combustions and near the emissions of regional road transports (http://www.arpa.veneto.it/arpavinforma/indicatori-ambientali/indicatori-ambientali-delveneto/atmosfera/emissioni/emissioni-in-atmosfera-di-gas-ad-effetto-serraco2-ch4-n2o-inemar2010/view).

In conclusion, conservation agriculture may have a relatively strong transitory influence on the global greenhouse effect (within about 40 years). Nevertheless, it is necessary to implement new technologies in order to reduce and contrast greenhouse gas emissions.

Our example shows a process of reasoning that farmers and public services may contemplate for facing climate warming. A lower rate of SOC storage would be less efficient on a longer period of climatic mitigation. We did not consider other effects of conservation agriculture, in particular the increase of water retention capacity, with consequences on irrigation costs (negligible in our experience but relatively elevated by elsewhere) and on soil fertility and quality of human nutrition.

\section{Case of rarefaction of peat material in the main Swiss areas under vegetable production}


An important part of Swiss vegetable production is linked to the exploitation of drained peatlands. Having only a few coarse mineral particles, a high productivity and being relatively easy to cultivate, such soils are particularly well-adapted to the cultivation of vegetables and potatoes. Unfortunately these peat-rich soils are losing, in average, between 5 and $20 \mathrm{~mm}$ of thickness each year. This decrease is illustrated in Figures $12 a$ and $b$, showing a single location followed over subsequent years. This leads to a large $\mathrm{CO}_{2}$ emission, and a diminution of their general fertility due to water table nearing the surface. In addition to their importance for food production, these areas also play multiple and significant ecosystem services (e.g. agritourism, nature conservation, $C$ sequestration, water regulation; see e.g. Meli et al., 2014; Tonks et al., 2017).

In Switzerland this is for example the case in the Plaine de l'Orbe, Rheintal, Gurbetal or also in Seeland. In the latter region, ca. $20 \%$ of Swiss cultivated vegetables are produced in an area of about 6,000 ha. This is a wide marshy area partially drained during water corrections which occurred in Jura in 1860 and 1970 (see e.g. Meli et al., 2014; Tonks et al., 2017). In some Seeland locations the soils can be up to $150 \mathrm{~cm}$ lower than their original situation. This trend, as for other abovementioned Swiss areas, is linked to peat subsidence (e.g., during loss of water) and to the mineralisation of peat material. These effects are partially due to drainage as well as to soil compaction (e.g. caused by heavy vehicles). The relative contributions of these two processes, their intensities and origins are still to be determined more precisely.

\subsection{Examples of potential solutions}

Different solutions can be considered in order to maintain, or even restore the long-term fertility of these soils. (i) Raising the water table. By limiting the available depth for plant roots, it also limits certain agricultural practices or requires specific adaptations (e.g. paludiculture or machines with lower ground pressure). (ii) Bringing in an appropriate way adequate organic and/or mineral materials in order to compensate for lost thickness. Such material must imperatively have a light texture in order to avoid loss of permeability and present a favourable structure. This approach raises the issue of the quantity and quality of used materials as well as the way they are transported and deposited to the targeted field. Such practices can in certain cases induce a compaction of the underlying horizons, especially those rich in peat material and having a high organic/mineral ratio. (iii) Mixing surface organic horizons with deeper sandy ones could also be possible. It requires the presence of a mineral horizon with a light texture in order to avoid problems such as waterlogging.

\subsection{Conclusions}

Drained wetland soils are however a very complex system and the few solutions mentioned above can assuredly not be applied uniformly throughout the whole considered area. A system like Seeland results from a fluvial/lacustrine system and thus presents an important pedological and hydrogeological spatial (and temporal) complexity (see e.g. Magny et al., 2005; Pugin, 1991). Over 
only $10 \mathrm{~m}$ (horizontal) the thickness of peat material can for example range from 30 to 300 centimetres. Different conditions of past sediment deposition can also lead to a high textural variability of mineral horizons and a high number of different layers in the soil profile. Moreover, the delimitation of the different agricultural parcels rarely corresponds to the natural functional units of the considered system.

This implies the need to know as well as possible the studied areas in order to take appropriate management measures and choices. It is therefore necessary to: (i) Map the soils (e.g. spatial variability, thickness, horizon and material types, water regime) using an adapted observational scale and methodology. (ii) Develop a typology to better characterise peat materials and their potential of compaction. Although many studies have already been focused on the characterisation of peats, these results are difficult to transpose to agricultural systems such as Seeland. Soil materials present in this area are mostly very different from the "pure" peat material encountered in raised bogs and the products of peat degradation differ from natural peat composition. The typology to develop should allow defining as well as possible the potential of soil settlement, the agricultural properties or even the hydraulic properties of the considered areas.

The complex problem encountered in the Seeland is also present in various other regions (see e.g. Brouns et al., 2015; Gambolati et al., 2006; Querner et al., 2012; Wösten et al., 1997). In Ireland, peat exploitation began 400 years ago. The Irish Peatland Conservation Council try to program the sustainable management of these precious ecosystems: http://www.ipcc.ie/a-to-zpeatlands/peatland-action-plan/overexploitation-of-peatlands-for-peat/. This deserves to be carefully considered in order to maintain the fertility of such soils and consequently a stable and reliable production as well as to limit $\mathrm{CO}_{2}$ emission.

The soil use and protection group from the School of Agricultural, Forest and Food Sciences HAFL (Bern University of Applied Sciences, BFH) is currently developing and applying mapping methods adapted to this complex situation. At the same time, a typology and an index allowing a better characterisation of these peat materials are under development. The results can then be directly applicable in an agricultural context, at minimal cost and for large heterogeneous areas.

\section{Soil carbon 4 per 1000 - feasible or naive?}

The Paris climate change agreement reached in December 2015 has been ratified by more than 100 countries, for the first time in 20 years of UN (United Nations) negotiations, to achieve a legally binding and universal agreement on climate, with the aim of keeping global average temperature well below $2^{\circ} \mathrm{C}$ above pre-industrial levels. In order to achieve this target, annual greenhouse gas emissions need to be reduced (Meinshausen et al., 2009; Stockmann et al., 2015; Minasny et al., 2017a and b).

During COP21, the French Minister of Agriculture Stéphane Le Foll also set an ambitious international research program, called " 4 pour mille" or " 4 per 1000 ", to demonstrate that agricultural soils can play a crucial role in food security and climate change mitigation. 4 per 1000 refers to the hope to increase annually global soil organic matter stocks by 4 per 1000 (4\%) with the 
implementation of best farming practices. This annual increase of organic matter in soil is offered as a compensation for the global emissions of greenhouse gases by anthropogenic sources. This Initiative aspires to bring together all volunteers in public and private sectors under the framework of the Lima-Paris Action Agenda (LPAA). This initiative was supported by almost 150 signatories (countries, regions, international agencies, private sectors and NGOs) in December 2015.

As we all know, soils store lots of C! At about 2,400 billion tonnes $\left(2400 \times 10^{15} \mathrm{~g}\right)$ of $\mathrm{C}$, soil is the largest terrestrial $C$ pool (Fig. 13). The top $2 \mathrm{~m}$ of soil hold 4 times the amount of $C$ that is stored in plant biomass. Soils also have the potential to store $\mathrm{C}$ for a very long time by various protective mechanisms.

The conversion of forested and native vegetation areas into cultivated crops has led to an overall decline of $50 \%$ of SOC stocks (Luo et al., 2010). Nevertheless, good agricultural management can reverse this trend, and increase $C$ sequestration in soils. Restoring soil's $C$ content is a win-win situation, as it offsets greenhouse gas emissions and provides benefits of enhanced soil quality. Increasing soil $\mathrm{C}$ has an important role in soil and water conservation: increasing soil aggregate stability results in reduced erodibility. It also increases soil nutrient cycling capacity, which can help tackling global issues of soil, food, water, and energy security.

The potential of soil to sequester $\mathrm{C}$ for offseting greenhouse emissions has been widely debated. So how can we realistically increase soil organic matter stock by 4 per 1000 on a year-toyear basis? First, we need to understand from where " 4 pour mille" or 4 per 1000 came from. Annual greenhouse gas emissions from fossil fuel are estimated at 8.9 billion tonnes $C\left(8.9 \times 10^{15} \mathrm{~g}\right)$, and global soil $\mathrm{C}$ stock to $2 \mathrm{~m}$ depth is estimated at 2,400 billion tonnes $\left(2,400 \times 10^{15} \mathrm{~g}\right)$ (Batjes, 1996). Taking the ratio of global anthropogenic $C$ emissions over total soil organic $C$ stock at $8.9 / 2,400$ results in a value about 4 per 1000 or $0.4 \%$. But to come up with a meaningful number to be used by farmers, we need to work out how much $C$ the soil is storing on a per hectare basis. Four per 1000 of this total estimate will then give us the required annual sequestration rate that needs to be achieved to reach the aspiration.

Let's first look at the global context. The land area of the world is 149 million $\mathrm{km}^{2}$, and it could be estimated that on average there are $161 \mathrm{t}$ of $C$ per hectare. So, 4 per 1000 equates to an average sequestration rate to offset emissions of $0.6 \mathrm{t}$ of $\mathrm{C}$ per hectare per year. We know that soil varies widely in terms of $C$ storage, for example peat soils in the tropics hold about $4000 \mathrm{t}$ of $\mathrm{C}$ per hectare, while sandy soils in arid regions may only hold $80 \mathrm{t}$ of $\mathrm{C}$. The type of aboveground vegetation and how quickly soil biota use $\mathrm{C}$ also can affect this rate. Taking this into account, we would need to add about 4 times the present amount of organic matter to meet this sequestration rate. The aspirational global sequestration rate is depicted in Figure 14. The $\mathrm{C}$ sequestration rate varies from $0.2 \mathrm{t}$ per year in agricultural regions of Australia and the US to $1 \mathrm{t}$ per year in boreal areas. So clearly 4 per 1000 cannot be applied everywhere.

\subsection{Soil $C$ sequestration rates}


Studies across the globe have measured soil $\mathrm{C}$ sequestration rates after best management practices with rates varying from 0.1 to $0.5 \mathrm{t}$ of $\mathrm{C}$ per hectare per year. These estimates do change however with soil type and climatic regions. Rates calculated from a global meta-analysis by West and Post (2002) suggest an average sequestration rate of $0.48 \pm 0.13 \mathrm{t} \mathrm{C} /$ ha/year for conversion from conventional to no tillage. Crop rotations have an average sequestration rate of $0.15 \pm 0.04 \mathrm{t}$ $\mathrm{C} /$ ha/year. A meta-analysis from the study by Lam et al. (2013) showed estimates of $C$ sequestration rates in Australia after adoption of conservation tillage, plant residue management and conversion to pasture (Table 7). The overall sequestration rates are lower than those reported by West and Post (2002), ranging from 0 to $0.3 \mathrm{MgCha}{ }^{-1}$ year $^{-1}$, which translates to 0 to 20 per mille annually.

Australia can be considered one of the worst $\mathrm{C}$ emitters per capita. Current annual $\mathrm{CO}^{2}$ emissions from fossil fuel are 390 million tonnes (or $10^{6} \times 10^{12} \mathrm{~g} \mathrm{C}$ ). If we use $\mathrm{C}$ stock estimates for Australian topsoil as 25,000 million tonnes (or $25,000 \times 10^{12} \mathrm{~g}$ ), then the ratio of $\mathrm{C}$ emissions over soil C stock is remarkably at 4 per 1000 . If we consider the proportion of agricultural land at 470 million hectares, then annually we need to sequester an average of $0.22 \mathrm{t}$ of $\mathrm{C}$ per hectare. This value falls within the estimation of sequestration rates shown in Table 1 for best management practices in Australia where water is not severely limiting.

\subsection{Is it practicable?}

The potential to increase $\mathrm{SOC}$ is mostly in managed agricultural land. In situ management strategies that have been found to increase soil $C$ include stubble retention, reduced tillage and crop rotation. A large part of potential organic amendments in the world is largely under-utilized (Chabbi et al., 2017), such as for instance urban waste and sewage sludge. There is a large amount of crop residues that have been mismanaged and burnt (Streets et al., 2003; Zhang et al., 2015). Take for example global crop residue, based on the calculation of Smil (1999). The 2014 global crop yield is 8.9 Gt according to FAO. Taking into account average moisture content, and mean harvest index, we have approximately $6 \mathrm{Gt}$ of crop residues. Assuming that only $15 \%$ of this residue will become soil organic carbon, there is a potential annual contribution of $0.9 \mathrm{Gt} C$ just from crop residues which were wasted.

Another source of organic material is urban waste: when composted it can be added as soil amendment in urban agricultural areas for $\mathrm{C}$ sequestration and nutrient cycling. There is also an enormous potential for SOC improvement in poorly managed and degraded soils.

Any increase in soil C, even only in the topsoil, should benefit crop soil, which has lost half of its $\mathrm{C}$ since it has been used for cultivation. The challenge for cropping farmers is to find a new generation of practices that will further improve soil condition and deliver increased soil C. SOC sequestration should be the outcome of improved farming practices that increase productivity, which in turn build up organic matter. We need disruptive technologies that can help agricultural practices to soak up more $\mathrm{C}$ in the soil, create soil security to achieve food security and mitigate climate change. 
Areas that have reached equilibrium although not at saturation level will not be able to increase their sequestration rate. Because of small SOC stock gain per unit area when best management practices are applied, the 4 per 1000 can only offer short-term solutions. Only radical soil management coupled with enhanced $C$ sequestration technology in productive agricultural land has the potential to mitigate climate change (McBratney et al., 2016).

The 4 per 1000 is an ambitious aspiration, however it is setting for the first time a global goal to promote good soil management that can help mitigate climate change. It is imperative that soil and agriculture be part of the solution. It should be noted that the 4 per 1000 is more a concept than a specific number. We can view it as an aspiration to curb Earth warming to just an additional $2^{\circ} \mathrm{C}$. It is also one of many national and global initiatives on $\mathrm{SOC}$ sequestration for mitigating climate change, such as by the Technical Panel on Soils (ITPS) of the Global Soil Partnership (GSP), the IPCC, the Global Research Alliance on Agricultural Greenhouse Gases (GRA) and so on.

As it is an aspirational target, of course there are limitations, e.g. time constraints in the capacity of soils to sequester carbon, nutrient limitations to build up organic matter, longevity of carbon in the soil and so on. It is a temporary solution that buys time over the next ten years whilst other effective sequestration and low $\mathrm{C}$ technologies will become viable.

Advances in 4 per 1000 initiative requires collaboration and communication between scientists, farmers, policy makers, and marketers (Fig. 15). Farmers and land managers mainly utilise best management practices to improve yields and soil condition and, in doing so contribute to sequestering SOC and mitigating climate change. Soil scientists provide new research that can result in enhanced $C$ sequestration, monitoring of the impact of climate change on SOC, and improving our knowledge of SOC functioning. Scientists also develop new technologies in measurement, mapping, and auditing to verify SOC sequestration which is expected by the market to provide confidence in investment. Farmers' SOC sequestration effort provides compliance to policy makers. This has to be integrated with institutional regulations and policies that facilitate market-based approaches, such as C trading.

Minasny et al. (2017a and b) demonstrated that SOC sequestration goal of the 4 per mille initiative is seen as a worthy pursuit for scientists from 20 countries and regions of the world. However, this goal is not achievable everywhere, and moreover it is finite in time/duration. Nevertheless, we should be optimistic with this aspirational target and use the best empirical evidence to work on it.

\section{Conclusions of article 19}

1) Can we grow potatoes on Mars?

Yes, provided we can create an ecosystem that allows for cultivation of plants on Mars (discussed in Section 1 of the article). We should furnish artificial surrogates of atmosphere, hydrosphere, geosphere and biosphere. It is possible to build a greenhouse on Mars, exactly as in Andy Weir's novel "The Martian". Results would be somewhat less encouraging than those obtained 
by Matt Damon in the film, but possible. The more artificial soil resembles a humus system, the better the growth. Potato plants are living organisms. They will adapt to a Martian habitat and react to the environment we furnish to them. We suggest creating a whole ecosystem in the greenhouse, inhabited by microorganisms living in air and water, disposing lichens and mosses as "islands" on the floor of the greenhouse, and adding even some soil animals such as nematodes, enchytraeids and collembolans, letting them to co-evolve with lichens and mosses. Little by little these islands will have a real soil under them, joining each other (some attractive nutritious substances may be disposed between islands) and covering the whole greenhouse. Potato plants may be cultivated in this soil and will probably grow.

On Earth, an experiment in controlled conditions, with a standard climate, using simulants of soils from the Moon or Mars improved our knowledge on these soils. Wamelink et al. (2014) showed that "plants are able to germinate and grow on both Martian and Moon soil simulant for a period of 50 days without any addition of nutrients.[...] Reflexed stonecrop (a wild plant); the crops tomato, wheat, and cress; and the green manure species field mustard performed particularly well. The latter three flowered, and cress and field mustard also produced seeds."

We like the idea to go and play football on Mars, and even farther, around another star. Why not trying to live well and peaceful on Earth, first? We need to evolve a little more, mastering cell genesis and evolution, better understand bacteria and fungi, be sure about ecological relationships among living beings and their environment, and have better means of extragalactic transport. To go and live on the Moon would be hard enough. Let's start with the Moon, if we cannot be waiting.

2) Is there a main general principle of agriculture?

Yes, it is to feed soil, not plants (Section 2). Plants being autotrophic organisms, we cannot feed them directly as if they were animals. It is an anthropomorphic view we have to abandon. The concept of "soil fertility" should be abandoned to the benefit of "soil health" sensu Kibblewhite et al. (2008).

We suggest to follow three main rules of agriculture (Section 3). They have been published by three researchers:

a. Masanobu Fukuoka (Fukuoka, 1985): an ecosystem gets his own complex life. Humans are part of it. In his own words (Fukuoka, 1985): "Life on earth is a story of the birth and death of individual organisms, a cyclic history of ascendance and fall, thriving and failure, of communities.[...] If we have to give a name to this fundamental law, we could call it the 'Dharmic Law That All Things Return to One'. All things fuse into a circle, which reverts to a point, and the point reverts to nothing. To Man, it appears as if something has occurred and something has vanished, yet nothing is ever created or destroyed. This is not the same as the scientific law of the conservation of matter. Science maintains that destruction and conservation exist side by side, but ventures no further";

b. Allan Savory (Savory and Butterfield, 2016): a naturally grazed area does not degrade by itself. If humans want to use it as source of food, they have to integrate the area while respecting its natural functionality; 
c. Jeff Lowenfels (Lowenfels and Wayne, 2010): artificial soils have to resemble natural ones (with, of course, the soil type depending on the purpose, i.e. the cultivated ecosystem). The more they resemble natural soils, the more they will be manageable.

3) Is there a natural reference humus system for agricultural purposes?

Yes, in most cases it is the Mull system. Its functioning is well known, especially in temperate climates, where earthworms dominate and control soil development (Section 4). A systemic interpretation is proposed in Lavelle et al. (1993) and Cluzeau et al. $(1988,2012)$. In tropical and subtropical climates, arthropods lead the evolution of these topsoils (Decaëns et al., 2004) and form arthropod Mull systems. The management of arthropod Mull systems is still arduous in artificialized crop dry environments.

4) Are there other particular humus systems involved in agricultural processes?

Yes, hydroponic systems. As for less artificial processes, we should consider costs and quality of produced food. Peat systems (Section 6) should ideally be submitted to a cycle of restoration, with a long-term period of re-submersion.

5) Is it possible to use the soil as a carbon sink?

Yes, it is not only possible but even mandatory. It is very hard and very expensive to replace soil with another artificial interface between plants and animals. The reuse of the energy produced by plants and animals at the level of soil is crucial for every terrestrial ecosystem on Earth. Human population increasing at an unprecedented rate, life on Earth risks falling short of energy and nutrients without soil. The present-day solution which has been adopted by agriculturists is to replace consumer species (and other natural processes) by mechanical and chemical inputs, reducing the biodiversity of the planet. We do not think that this solution is sustainable.

Being among the last-born species of primates - genus Homo appeared in the history of evolution about 7 million years ago - humans are the fruit of a long co-evolution still depending from other species. Humans became relatively independent from their habitat. Humans have more technological skills than other species. Humans can decide to kill or let alive themselves and many other organisms. Humans are even trying to control virus and microorganisms.

We do not know whether God has something to do with mankind. Better to think that we are fully responsible of the future of mankind, which does not seem in contradiction with any main religious belief. Are we intelligent enough for surviving in the ongoing century on planet Earth and with a consistent, necessary number of other living organisms? Are we intelligent enough for understanding that becoming nearly 10 billion of humans in the forthcoming 20-30 years, we need to preserve the natural resource for ensuring food and water for everybody and for the next generations? The solution that is on the road is not reassuring. We let mankind diverging in three main groups of people; very roughly: $1-5 \%$ of very rich, powerful and meanly cultivated people, orientating the world economy in accordance with their financial needs; $30-40 \%$ of middle class, meanly cultivated people, giving life to relatively democratic societies, ensuring mankind education, cure, science development, travel conditions for exchanges, telecommunication, legislation and general societal organisation; and at least $50-70 \%$ of multi-dimensionally poor people (with $10 \%$ of undernourishment) with a lower level of education (they do not have enough financial income), 
trying to survive as far as possible, which could be even in a very bad condition, or migrate. Can this type of mankind structure overpass the real challenge that is scientifically forecasted for the forthcoming $20-30$ years?

World economy is mostly controlled by soil, climatic and cultural constraints which are distal factors acting on crop production and demographic patterns. Even if poor people are a bit less poor than in past time, differences in richness between very rich and all other people continue to increase. Reducing this inequity is a major concern if we want to find a sustainable model of development. As for food and water, money should circulate. Institutions should fight against stagnation. Keynes solved the 1929 crisis by creating employments and welfare through public investment in services (e.g., roads, power lines, railways). It is time to invest in the amelioration of natural resources, by improving the quality of water, air and soil. This means relating incomes to natural resources and human health. On this way, sustainable agriculture is a very good solution.

6) Very important, to farmers:

a) Water soil capacity and water availability for plants are related to soil organic matter, in particular in soils impoverished in clay particles, often a side-effect of deforestation (Hajabbasi et al., 1997). However, this organic matter has to be functional, i.e. be humified and integrated in biologically formed soil aggregates (see Sections 4 and 5). It is not the quantity (Minasny and Mcbratney, 2017) but the quality of soil organic matter that makes the difference (Cluzeau et al., 2012; Bouché, 2014), and this quality is related to soil biodiversity (Bhatia, 2008; Lange et al., 2015; Prashar and Shah, 2016). Detailed information about the relationship between soil biological functioning soil and food quality is given in Humusica 2, article 17.

b) In the soil occurs the process of recycling of dead structures (plant, microbial and animal organic remains) (Humusica 1 articles 1 and 7). These organic structures are dismantled in the soil. The basic units composing organic remains are rearranged in new functional structures. This is the reason why the quality of the soil ("soil health") is related to the quality of the produced food. For instance, this principle is at the origin of many DOC wines, wines whose Origin is Controlled (meaning that the area, i.e. the particular soil-plant system in a given climate, the so-called "terroir", is circumscribed and saved). In the market, it is not rare to have a label on fruits (very common on apples) for the same reason.

c) If farmers want to save the quality of a particular soil, they must feed its organisms with caution and cure them. They should try to preserve them in good health and in equilibrium with the crop system. We suggest to consider the original vegetation of the site and to try to feed the soil with litter from plants of this original vegetation, however without excessive use of this resource, knowing that in western Europe forest soils have been strongly impoverished by this practice in the Middle Ages. To avoid litter and nutrients coming from other geological plates, is better to stay within a given valley (example a same Alpine valley, in order to preserve the specific qualities of a given apple variety) or a relatively confined region (vineyards in a particular ecological situation).

d) A changing climate will impose important modifications at the level of soil organisms and soil functioning. Potential vegetation will change, too. Instead of pointing to a given fixed soil quality, it is better to point to a given healthy soil in harmony with the climate and potential vegetation of a 
given restricted region. It should always warrant the production of good food, which may change in taste, but not in fundamental quality.

e) Soil protection is often erroneously opposed to crop production, as holidays are opposed to working days. In an agricultural context, the main aim of soil protection is not restrictions/limitations for the farmer, but really to maintain - or even more to promote - a good production, and this in a sustainable way; i.e. not only for the few years to come, but rather for the many generations to come. What we hope is a right equilibrium between protection and production. This is not far from Masanobu's principle of understanding the natural evolution and following the movement of production, distribution and recycling for an infinite number of turns. It is a principle of life. We must respect the whole as a mysterious inaccessible universe (accessible little by little, however), something like an evolving pendulum (cyclical), made for generating and recycling living music (DNA variations/functional constructions), and that forever.

7) Is Homo sapiens the most intelligent organism living on Earth?

Only YES or NO answer allowed, with a short explanation (Figs. 16a and b)

A. Zanella (University of Padua, Italy)

Yes.

Homo sapiens is the most intelligent organism living on Earth. Humans know that the sun will die. They even know that space and time, as well as life and death, are interdependent. Today, this species represents the best fruit of natural evolution, even if we restrict "intelligence" to an innate attitude to reproduction and use of the environment as source of energy and nutrients.

C. Bolzonella (University of Padua, Italy)

No.

Homo sapiens is not the most intelligent organism living on Earth. About the definition of "intelligence", when we think that we are at the summit of the evolution, it is a demonstration that we are unintelligent or probably only blind. I think that intelligence is correlated (synonymous) with "adaptability" when we take into account the effects not at the individual level but at the species level. We know what we built for our needs in our, or close to, our habitat, but we don't know what other forms of life have built for their needs. Remember that also bacteria and viruses have gone to the Moon (inside human bodies).

J.-F. Ponge (Museum National d'Histoire Naturelle, Paris, France)

No.

Just a remark about intelligence: we now know that there are various forms of intelligence, even among humans (some of them badly adapted to scholar education), and that many animals are capable of "intelligence", even if this intelligence is not directed to technology, but rather to artistic or strategic skills. Please cease to put humans at the summit of evolution, just below God or Gods. We should be more modest, and the Humusica project should contribute to that, in its manner. And do not forget that viruses, too, are evolving and that out of the control of mankind (e.g., AIDS). 
M. Bouin (Université de Bourgogne, Dijon, France)

No.

If we consider that intelligence is the ability for an organism to be adapted to its environment, I think that viruses and microorganisms are far more intelligent than us since they appeared 3.8 billion years ago and are still on Earth despite major evolutionary crises which eliminated all big organisms unable to support rapid changes. But we could consider that intelligence is a specific way of "staying alive": Patten (1997) stated that "Living things make models". This conjecture gives a modelling oriented definition of life. Whereas all organisms (including humans) make biochemical models of their environment through their networks of molecules, the human species has developed a specific organ to make models: the brain. Thanks to his/her brain, he/she is able to predict some consequences of potential actions and to choose among the most beneficial ones. According to the huge modifications of the planet and the increasing size of the human population, we could be tempted to say that Homo sapiens is the most intelligent species. It is a shame that our cognitive models are so imperfect and/or that our sense of responsibility and ethics are so weak that negative consequences of our actions are becoming dramatic and maybe one day more detrimental for our fitness than the positive consequences of our intelligence.

S.S. Kukal (Pennsylvania State University, Philadelphia, USA)

No.

Homo sapiens is the most selfish animal on this planet, who is destroying the most important "carbon cycle" provided by Nature and which is based on the simple principle that "whatever has been produced by the soil, should be recycled back into the soil, whether from plant or animal kingdom". Of course, soil is a source as well as a sink for carbon which depends upon anthropogenic activities which we follow. Bad practices could lead to carbon source whereas good practices could lead to carbon sequestration.

I. Fritz (Universität für Bodenkultur Wien, Austria)

No.

It is not necessary to be intelligent, it is necessary to have an established behaviour pattern (meant on species level) that let us surviving. Humans have that. What we do not have is a behaviour pattern that would improve our life without harming other life forms. Such a behaviour would require intelligence to dominate over drive.

D. Tatti (BFH University of Applied Sciences, Zollikofen, Switzerland)

No.

Depending on the definition of intelligence I found once my office neighbour is far more intelligent than me (as a human). P.S. This neighbour is a Corylus avellana L.

\section{Authors' contributions}


Augusto Zanella: coordinator, article structure and composition, selection of authors and themes, redaction/contribution of chapters 1, 2, 3, 3.1, 3.2, 4, 5;

Cristian Bolzonella, Luigi Sartori: redaction of chapter 5; scientific support;

Jeff Lowenfels: redaction of chapter 3;

Marcel Bouché: author of the book "Des vers-de-terre et des hommes" (Bouché, 2014); A. Zanella: selection of chapters, J.F. Ponge: translation in English;

Jean-François Ponge, Manuel Blouin: contribution to chapter 1, revision of the whole manuscript;

Debasish Saha, Surinder Singh Kukal: redaction of chapter 4.2;

Ines Fritz: contribution to chapters 2, 3.1; scientific support;

Allan Savory: redaction of chapter 3.2;

Dylan Tatti, Lev Kellerman, Peter Trachsel, Stéphane Bourgois: redaction of chapter 6;

Budiman Minasny: redaction of chapter 7;

Manasobu Fukuoka: honorary authorship, chapter 3.1.

\section{References}

ARPAV, 2010. La qualità dei suoli, stock di carbonio organico nello strato superficiale di suolo. http://www.arpa.veneto.it/arpavinforma/indicatoriambientali/indicatori ambientali/geosfer a/qualita-dei-suoli/stock-di-carbonioorganico-nello-strato-superficiale-di-suolo.

Abbott, L.K., Murphy, D.V., 2003. Soil Biological Fertility: A Key to Sustainable Land Use in Agriculture. Springer, Dordrecht.

Ademe, 2015. Organic Carbon in Soils, Meeting Climate Change and Food Security Challenges. http://www.ademe.fr/sites/default/files/assets/documents/organic carbon in soils gb 85 75.pdf.

Agnelli, A., Ascher, J., Corti, G., Ceccherini, M.T., Nannipieri, P., Pietramellara, G., 2004. Distribution of microbial communities in a forest soil profile investigated by microbial biomass, soil respiration and DGGE of total and extracellular DNA. Soil Biol. Biochem. 36, 859-868.

Agriculteurs Composteurs de France, 2015. Charte de bonnes pratiques de compostage agricole. http://www.composteursdefrance.com/ressources/pdf/charte bonnes pratiques composta ge.pdf. 
Aira, M., Sampedro, L., Monroy, F., Domínguez, J., 2008. Detritivorous earthworms directly modify the structure, thus altering the functioning of a microdecomposer food web. Soil Biol. Biochem. 40, 2511-2516.

Alfieri, L., 2013. Agricoltura conservativa. Universitã Degli Studi di Milano. https://docslide.net/documents/agricoltura-conservativa-56cd3c0a45748.html

Ammann, K., 2005. Effects of biotechnology on biodiversity: herbicide-tolerant and insect-resistant GM crops. Trends Biotechnol. 23, 388-394.

Andreux, F., 1996. Humic substances in terrestrial ecosystems. In: Piccolo, A. (Ed.), Humic Substances in Terrestrial Ecosystems. Elsevier, Amsterdam, pp. 45-100.

Barberán, A., Ladau, J., Leff, J.W., Pollard, K.P., Menninger, H.L., Dunn, R.R., Fierer, N., 2015. Continental-scale distributions of dust-associated bacteria and fungi. Proc. Natl; Aced; Sci. USA 112, 5756-5761.

Bardgett, R.D., Van der Putten, W.H., 2014. Belowground biodiversity and ecosystem functioning. Nature 515, 505-511.

Barea, J.M., Pozo, M.J., Azcon, R., Azcon-Aguilar, C., 2005. Microbial co-operation in the rhizosphere. J. Exp. Bot. 56, 1761-1778.

Barot, S.M., Blouin, M.S., Fontaine, S.P., Jouquet, P.J.C., Lata, J.C., Mathieu, J., 2007. A tale of four stories: soil ecology, theory, evolution and the publication system. PLoS ONE 2, e1248.

Batjes, N.H., 1996. Total carbon and nitrogen in the soils of the world. Eur. J. Soil Sci. 47, $151-163$.

Baveye, P.C., Berthelin, J., Munch, J.C., 2016. Too much or not enough: reflection on two contrasting perspectives on soil biodiversity. Soil Biol. Biochem. 103, 320-326.

Beare, M.H., Parmelee, R.W., Hendrix, P.F., Cheng, W., Coleman, D.C., Crossley, D.A., 1992. Microbial and faunal interactions and effects on litter nitrogen and decomposition in agroecosystems. Ecol. Monogr. 62, 569-591.

Bedano, J.C., Cantú, M.P., Doucet, M.E., 2006. Influence of three different land management practices on soil mite (Arachnida: Acari) densities in relation to a natural soil. Appl. Soil Ecol. 32, 293-304.

Benckiser, G., 1997. Fauna in Soil Ecosystems: Recycling Processes, Nutrient Fluxes, and Agricultural Production. Marcel Dekker, New York.

Berg, B., Laskowski, R., 2006. Litter Decomposition: A Guide to Carbon and Nutrient Turnover. Academic Press, San Diego.

Bhatia, C.R., 2008. Role of microbial diversity for soil, health and plant nutrition. In: Nautiyal, C.S., Dion, P. (Eds.), Molecular Mechanisms of Plant and Microbe Coexistence. Springer, Berlin.

Blagodatskaya, E., Kuzyakov, Y., 2013. Active microorganisms in soil: critical review of estimation criteria and approaches. Soil Biol. Biochem. 67, 192-211. 
Blankinship, J.C., Fonte, S.J., Six, J., Schimel, J.P., 2016. Plant versus microbial controls on soil aggregate stability in a seasonally dry ecosystem. Geoderma $272,39-50$.

Bonduriansky, R., Day, T., 2009. Nongenetic inheritance and its evolutionary implications. Annu. Rev. Ecol. Evol. Syst. 40, 103-125.

Bouché, M.B., 2014. Des Vers de Terre et des Hommes. Actes Sud, Arles.

Boudsocq, S., Niboyet, A., Lata, J.C., Raynaud, X., Loeuille, N., Mathieu, J., Blouin, M., Abbadie, L., Barot, S., 2012. Plant preference for ammonium versus nitrate: a neglected determinant of ecosystem functioning? Am. Nat. 180, 60-69.

Brenna, S., Acutis, M., Acutis, Ballarin Denti A., Gardi, C., Gerosa, G., Valagussa, M., Lapi, M., 2013. II ruolo dell'agricoltura conservative nel bilancio del carbonio. Quaderni della Ricerca 153, 1148.

Brennan, E.B., Acosta-Martinez, V., 2017. Cover cropping frequency is the main driver of soil microbial changes during six years of organic vegetable production. Soil Biol. Biochem. 109, 188-204.

Brouns, K., Eikelboom, T., Jansen, P.C., Janssen, R., Kwakernaak, C., Van den Akker, J.J.H., Verhoeven, J.T.A., 2015. Spatial analysis of soil subsidence in peat meadow areas in Friesland in relation to land and water management climate change, and adaptation. Environ. Manage. 55, 360372.

Brown, G.G., Barois, I., Lavelle, P., 2000. Regulation of soil organic matter dynamics and microbial activity in the drilosphere and the role of interactions with other edaphic functional domains. Eur. J. Soil Biol. 36, 177-198.

Brussard, L., 2012. Ecosystem services provided by the soil biota. In: Wall, D.H., Bardgett, R.D., Behan-Pelletier, V., Herrick, J.E., Jones, T.H., Ritz, K., Six, J. (Eds.), Soil Ecology and Ecosystem Services. Oxford University Press, Oxford, pp. 45-58.

Buchkowski, R.W., Schmitz, O.J., Bradford, M.A., 2015. Microbial stoichiometry overrides biomass as a regulator of soil carbon and nitrogen cycling. Ecology 96, 1139-1149.

Buckley, D.H., Schmidt, T.M., 2003. Diversity and dynamics of microbial communities in soils from agro-ecosystems. Environ. Microbiol. 5, 441-452.

Burger, M., Jackson, L.E., 2005. Plant and microbial nitrogen use and turnover: rapid conversion of nitrate to ammonium in soil with roots. Plant Soil 266, 289-301.

Butterfield, J., Bingham, S., Savory, A., 2006. Holistic Management Handbook: Healthy Land, Healthy Profits. Island Press, Washington, D.C.

Cartenì, F., Bonanomi, G., Giannino, F., Incerti, G., Vincenot, C.E., Chiusano, M.L., Mazzoleni, S., 2016. Self-DNA inhibitory effects: underlying mechanisms and ecological implications. Plant Signal. Behav. 11, e1158381. 
Chabbi, A., Lehmann, J., Ciais, P., Loescher, H.W., Cotrufo, M.F., Don, A., SanClements, M., Scippper, L., Six, J., Smith, P., Rumpel, C., 2017. Aligning agriculture and climate policy. Nature Climate change 7, 307-309.

Chandler, M., 2006. Molecular biology: singled out for integration. Nature 440, 1121-1122.

Clarholm, M., 1989. Effects of plant-bacterial-amoebal interactions on plant uptake of nitrogen under field conditions. Biol. Fertil. Soils 8, 373-378.

Cluzeau, D., Fayolle, L., Burakowski, I., 1988. Impacts sur les lombriciens des traitements pesticides, en particulier cupriques, dans le vignoble champenois. C. R. Acad. Agri. Fr. 8, 109-117.

Cluzeau, D., Guernion, M., Chaussod, R., Martin-Laurent, F., Villenave, C., Cortet, J., Ruiz-Camacho, N., Pernin, C., Mateille, T., Philippot, L., Bellido, A., Rougé, L., Arrouays, D., Bispo, A., Pérès, G., 2012. Integration of biodiversity in soil quality monitoring: baselines for microbial and soil fauna parameters for different land-use types. Eur. J. Soil Biol. 49, 63-72.

Copley, J., 2000. Ecology goes underground. Nature 406, 452-454.

Darwin, C., 1881. The Formation of Vegetable Mould Through the Action of Worms, with Observations on Their Habits. John Murray, London.

Dawkins, R., 2006. The Selfish Gene: 30th Anniversary Edition. Oxford University Press, Oxford.

Decaëns, T., Jiménez, J.J., Barros, E., Chauvel, A., Blanchart, E., Fragoso, C., Lavelle, P., 2004. Soil macrofaunal communities in permanent pastures derived from tropical forest or savanna. Agric. Ecosyst. Environ. 103, 301-312.

Deutschbauer, A.M., Chivian, D., Arkin, A.P., 2006. Genomics for environmental microbiology. Curr. Opin. Biotechnol. 17, 229-235.

Domínguez, J., 2004. State of the art and new perspectives on vermicomposting research. In: Edwards, C.A. (Ed.), Earthworm Ecology, $2^{\text {nd }}$ ed. CRC Press, Boca Raton, pp. 401-424.

Don, A., Schumacher, J., Scherer-Lorenzen, M., Scholten, T., Schulze, E.D., 2007. Spatial and vertical variation of soil carbon at two grassland sites: implications for measuring soil carbon stocks. Geoderma 141, 272-282.

FAO, 2017. What is Soil Carbon Sequestration? http://www.fao.org/soils-portal/soilmanagement/soil-carbon-sequestration/en/.

Fierer, N., Jackson, R.B., 2006. The diversity and biogeography of soil bacterial communities. Proc. Natl. Acad. Sci. USA 103, 626-631.

Fierer, N., Leff, J.W., Adams, B.J., Nielsen, U.N., Bates, S.T., Lauber, C.L., Owens, S., Gilbert, J.A., Wall, D.H., Caporaso, J.G., 2012. Cross-biome metagenomic analyses of soil microbial communities and their functional attributes. Proc. Natl. Acad. Sci. USA 109, 21390-21395.

Fitter, A.H., Gilligan, C.A., Hollingworth, K., Kleczkowski, A., Twyman, R.M., Pitchford, J.W., 2005. Biodiversity and ecosystem function in soil. Funct. Ecol. 19, 369-377. 
Fitter, A.H., 2005. Darkness visible: reflections on underground ecology. J. Ecol. 93, 231-243.

Fontaine, S., Barot, S., 2005. Size and functional diversity of microbe populations control plant persistence and long-term soil carbon accumulation. Ecol. Lett. 8, 1075-1087.

Food and Agriculture Organization (FAO), 2007. Conservation Agriculture. http://www.fao.org/ag/ca/.

Fritz, J.I., Franke, Franke-Whittle, I.H., Haindl, S., Insam, H., Braun, R., 2012. Microbiological community analysis of vermicompost tea and its influence on the growth of vegetables and cereals. Can. J. Microbiol. 58, 836-847.

Fujimura, K.E., Slusher, N.A., Cabana, M.D., Lynch, S.V., 2010. Role of the gut microbiota in defining human health. Expert Rev. Anti. Infect. Ther. 8, 435-454.

Fukuoka, M., 1985. The Natural Way of Farming: The Theory and Practice of Green Philosophy. Japan Publications, Tokyo.

Fulthorpe, R.R., Rhodes, A.N., Tiedje, J.M., 1998. High levels of endemicity of 3-chlorobenzoatedegrading soil bacteria. Appl. Environ. Microbiol. 64, 1620-1627.

Gajic, B., Dugalic, G., Djurovic, N., 2006. Comparison of soil organic matter content, aggregate composition and water stability of Gleyic fluvisol from adjacent forest and cultivated areas. Agron. Res. 4, 499-508.

Gambolati, G., Putti, M., Teatini, P., Gasparetto Stori, G., 2006. Subsidence due to peat oxidation and impact on drainage infrastructures in a farmland catchment south of the Venice Lagoon. Environ. Geol. 49, 814-820.

Gewin, V., 2006. Genomics: discovery in the dirt. Nature 439, 384-386.

Gleixner, G., 2013. Soil organic matter dynamics: a biological perspective derived from the use of compound-specific isotopes studies. Ecol. Res. 28, 683-695.

Gobat, J.M., Aragno, M., Matthey, W., 2010. Le Sol Vivant, $3^{\text {ème }}$ ed. Presses Polytechniques et Universitaires Romandes, Lausanne.

Gómez-Brandón, M., Ascher-Jenull, J., Bardelli, T., Fornasier, F., Sartori, G., Pietramellara, G., Arfaioli, P., Egli, M., Beylich, A., Insam, H., Graefe, U., 2017. Ground cover and slope exposure effects on micro- and mesobiota in forest soils. Ecol. Indic. 80, 174-185.

Gruber, K., 2015. Deep influence of soil microbes. Nature Plants 1, 15194.

Guinane, C.M., Cotter, P.D., 2013. Role of the gut microbiota in health and chronic gastrointestinal disease: understanding a hidden metabolic organ. Therap. Adv. Gastroenterol. 6, 295-308.

Habashi, H., 2016. Effect of forest and soil type on microbial biomass carbon and respiration. Eurasian Soil Sci. 49, 1084-1089. 
Hacquard, S., Garrido-Oter, R., González, A., Spaepen, S., Ackermann, G., Lebeis, S., McHardy, A.C., Dangl, J.L., Knight, R., Ley, R., Schulze-Lefert, P., 2015. Microbiota and host nutrition across plant and animal kingdoms. Cell Host Microbe 17, 603-616.

Hajabbasi, M.A., Jalalian, A., Karimzadeh, H.R., 1997. Deforestation effects on soil physical and chemical properties, Lordegan, Iran. Plant Soil 190, 301-308.

Han, L., Sun, K., Jin, J., Xing, B., 2016. Some concepts of soil organic carbon characteristics and mineral interaction from a review of literature. Soil Biol. Biochem. 94, 107-121.

Havlicek, E., Mitchell, E.A.D., 2014. Soils supporting biodiversity. In: Dighton, J., Krumins, J.A. (Eds.), Interactions in Soil: Promoting Plant Growth. Springer, Dordrecht, pp. 27-58.

Hernández, T., Chocano, C., Moreno, J.L., García, C., 2014. Towards a more sustainable fertilization: combined use of compost and inorganic fertilization for tomato cultivation. Agric. Ecosyst. Environ. 196, 178-184.

Hodge, A., Robinson, D., Fitter, A., 2000. Are microorganisms more effective than plants at competing for nitrogen? Trends Plant Sci. 5, 304-308.

Högberg, P., Nordgren, A., Buchmann, N., Taylor, A.F.S., Ekblad, A., Högberg, M.N., Nyberg, G., Ottosson-Löfvenius, M., Read, D.J., 2001. Large-scale forest girdling shows that current photosynthesis drives soil respiration. Nature 411, 789.

Hua, K., Wang, D., Guo, X., Guo, Z., 2014. Carbon sequestration efficiency of organic amendments in a long-term experiment on a Vertisol in Huang-Huai-Hai Plain, China. PLoS ONE 9, e108594.

Jastrow, J.D., Miller, R.M., Lussenhop, J., 1998. Contributions of interacting biological mechanisms to soil aggregate stabilization in restored prairie. Soil Biol. Biochem. 30, 905-916.

Jenny, H., 1941. Factors of Soil Formation: A System of Quantitative Pedology. McGraw-Hill, New York.

Johansson, J.F., Paul, L.R., Finlay, R.D., 2004. Microbial interactions in the mycorrhizosphere and their significance for sustainable agriculture. FEMS Microbiol. Ecol. 48, 1-13.

Jouquet, P., Bottinelli, N., Podwojewski, P., Hallaire, V., Tran Duc, T., 2008. Chemical and physical properties of earthworm casts as compared to bulk soil under a range of different land-use systems in Vietnam. Geoderma 146, 231-238.

Kallenbach, C.M., Frey, S.D., Grandy, A.S., 2016. Direct evidence for microbial-derived soil organic matter formation and its ecophysiological controls. Nature Commun. 7, 13630.

Kassam, T., Derpsch, F.R., Kienzle, J., 2015. Overview of the worldwide spread of conservation agriculture. Field Actions Sci. Rep. 8. http://factsreports.revues.org/3966.

Keiluweit, M., Bougoure, J.J., Nico, P.S., Pett-Ridge, J., Weber, P.K., Kleber, M., 2015. Mineral protection of soil carbon counteracted by root exudates. Nature Clim. Change 5, 588-595. 
Kibblewhite, M.G., Ritz, K., Swift, M.J., 2008. Soil health in agricultural systems. Phil. Trans. R. Soc. B $363,685-701$.

Kirchmann, H., Thorvaldsson, G., 2000. Challenging targets for future agriculture. Eur. J. Agron. 12, 145-161.

Kuzyakov, Y., Blagodatskaya, E., 2015. Microbial hotspots and hot moments in soil: concept and review. Soil Biol. Biochem. 83, 184-199.

Lal, R., 2014. World soils and the carbon cycle in relation to climate change and food security. In: Weigelt, J., Müller, A., Beckh, C., Töpfer, K. (Eds.), Soils in the Nexus: A Crucial Resource for Water, Energy and Food Security. Oekom, Munich. http://static.onleihe.de/content/oekom/20140929/978-3-86581-558-3/v978-3-86581-5583.pdf

Lal, R., Bruce, J.P., 1999. The potential of world cropland soils to sequester $C$ and mitigate the greenhouse effect. Environ. Sci. Policy 2, 177-185.

Lal, R., Negassa, W., Lorenz, K., 2015. Carbon sequestration in soil. Curr. Opin. Environ. Sustain. 15, 79-86.

Lam, S.K., Chen, D., Mosier, A.R., Roush, R., 2013. The potential for carbon sequestration in Australian agricultural soils is technically and economically limited. Sci. Rep. 3, 2179.

Lange, M., Eisenhauer, N., Sierra, C.A., Bessler, H., Engels, C., Griffiths, R.I., Mellado-Vázquez, P.G., Malik, A.A., Roy, J., Scheu, S., Steinbeiss, S., Thomson, B.C., Trumbore, S.E., Gleixner, G., 2015. Plant diversity increases soil microbial activity and soil carbon storage. Nature Commun. 6, 6707.

Lavelle, P., 2012. Soil as a habitat. In: Wall, D.H., Bardgett, R.D., Behan-Pelletier, V., Herrick, J.E., Jones, T.H., Ritz, K., Six, J., Strong, D.R., van der Putten, W.H. (Eds.), Soil Ecology and Ecosystem Services. Oxford University Press, Oxford, pp. 1-27.

Lavelle, P., Blanchart, E., Martin, A., Martin, S., Spain, A., 1993. A hierarchical model for decomposition in terrestrial ecosystems: application to soils of the humid tropics. Biotropica $25,130-150$.

Leff, J.W., Jones, S.E., Prober, S.M., Barberán, A., Borer, E.T., Firn, J.L., Harpole, W.S., Hobbie, S.E., Hofmockel, K.S., Knops, J.M.H., McCulley, R.L., La Pierre, K., Risch, A.C., Seabloom, E.W., Schütz, M., Steenbock, C., Stevens, C.J., Fierer, N., 2015. Consistent responses of soil microbial communities to elevated nutrient inputs in grasslands across the globe. Proc. Natl. Acad. Sci. USA 112, 10967-10972.

Lehmann, J., Kleber, M., 2015. The contentious nature of soil organic matter. Nature 528, 60-68.

Leigh, E.G. Jr., Rowell, T.E., 1995. The evolution of mutualism and other forms of harmony at various levels of biological organization. Écologie 26, 131-158.

Leigh, E.G. Jr., Vermeij, G.J., 2002. Does natural selection organize ecosystems for the maintenance of high productivity and diversity? Phil. Trans. R. Soc. Lond. B 357, 709-718. 
Leigh, E.G. Jr., 1983. When does the good of the group override the advantage of the individual? Proc. Natl. Acad. Sci. USA 80, 2985-2989.

Liu, S., Razavi, B.S., Su, X., Maharjan, M., Zarebanadkouki, M., Blagodatskaya, E., Kuzyakov, Y., 2017. Spatio-temporal patterns of enzyme activities after manure application reflect mechanisms of niche differentiation between plants and microorganisms. Soil Biol. Biochem. 112, 100109.

Lowenfels, J., Lewis, W., 2010. Teaming with Microbes: The Organic Gardener's Guide to the Soil Food Web. Timber Press, Portland.

Lowenfels, J., 2013. Teaming with Nutrients: The Organic Gardener's Guide to Optimizing Plant Nutrition. Timber Press, Portland.

Lowenfels, J., 2017. Teaming with Fungi: The Organic Grower's Guide to Mycorrhizae. Timber Press, Portland.

Luo, Z., Wang, E., Sun, O.J., 2010. Soil carbon change and its responses to agricultural practices in Australian agro-ecosystems: a review and synthesis. Geoderma 155, 211-223.

Lynch, J.M., Benedetti, A., Insam, H., Nuti, M.P., Smalla, K., Torsvik, V., Nannipieri, P., 2004. Microbial diversity in soil: ecological theories, the contribution of molecular techniques and the impact of transgenic plants and transgenic microorganisms. Biol. Fertil. Soils 40, 363-385.

McBratney, A., Koppi, T., Field, D.J., 2016. Radical soil management for Australia: a rejuvenation process. Geoderma Reg. 7, 132-136.

Maestre, F.T., Delgado-Baquerizo, M., Jeffries, T.C., Eldridge, D.J., Ochoa, V., Gozalo, B., Quero, J.L., García-Gómez, M., Gallardo, A., Ulrich, W., Bowker, M.A., Arredondo, T., Barraza-Zepeda, C., Bran, D., Florentino, A., Gaitán, J., Gutiérrez, J.R., Huber-Sannwald, E., Jankju, M., Mau, R.L., Miriti, M., Naseri, K., Ospina, A., Stavi, I., Wang, D., Woods, N.N., Yuan, X., Zaady, E., Singh, B.K., 2015. Increasing aridity reduces soil microbial diversity and abundance in global drylands. Proc. Natl. Acad. Sci. USA 112, 15684-15689.

Magny, M., Honegger, M., Chalumeau, L., 2005. Holocene fluctuations of the level of Lake Neuchatel (Switzerland): new data from the sediment sequence of Marin-Les-Piécettes. Ecl. Geol. Helv. 98, 249-259.

Malik, A.A., Chowdhury, S., Schlager, V., Oliver, A., Puissant, J., Vazquez, P.G.M., Jehmlich, N., von Bergen, M., Griffiths, R.I., Gleixner, G., 2016. Soil fungal: bacterial ratios are linked to altered carbon cycling. Front. Microbiol. 7, 1247.

Manlay, R.J., Feller, C., Swift, M.J., 2007. Historical evolution of soil organic matter concepts and their relationships with the fertility and sustainability of cropping systems. Agric. Ecosyst. Environ. 119, 217-233.

Masclaux-Daubresse, C., Daniel-Vedele, F., Dechorgnat, J., Chardon, F., Gaufichon, L., Suzuki, A., 2010. Nitrogen uptake, assimilation and remobilization in plants: challenges for sustainable and productive agriculture. Ann. Bot. 105, 1141-1157. 
Mazzoleni, S., Bonanomi, G., Incerti, G., Chiusano, M., Termolino, P., Mingo, A., Senatore, M., Giannino, F., Carteni, F., Rietkerk, M., Lanzotti, V., 2015a. Inhibitory and toxic effects of extracellular self-DNA in litter: a mechanism for negative plant-soil feedbacks? New Phytol. 205, 1195-1210.

Mazzoleni, S., Carteni, F., Bonanomi, G., Senatore, M., Termolino, P., Giannino, F., Incerti, G., Rietkerk, M., Lanzotti, V., Chiusano, M.L., 2015b. Inhibitory effects of extracellular self-DNA: a general biological process? New Phytol. 206, 127-132.

Meinshausen, M., Meinshausen, N., Hare, W., Raper, S.C.B., Frieler, K., Knutti, R., Frame, D.J., Allen, M.R., 2009. Greenhouse-gas emission targets for limiting global warming to $2^{\circ} \mathrm{C}$. Nature 458 , 1158-1162.

Meli, P., Benayas, J.M.R., Balvanera, P., Ramos, M.M., 2014. Restoration enhances wetland biodiversity and ecosystem service supply, but results are context-dependent: a metaanalysis. PLoS ONE 9, e93507.

Miltner, A., Bombach, P., Schmidt-Brücken, B., Kästner, M., 2012. SOM genesis: microbial biomass as a significant source. Biogeochemistry 111, 41-55.

Minasny, B., McBratney, A.B., 2017. Limited effect of organic matter on soil available water capacity. Eur. J. Soil Sci. (in press).

Minasny, B., Malone, B.P., McBratney, A.B., Angers, D.A., Arrouays, D., Chambers, A., Chaplot, V., Chen, Z.S., Cheng, K., Das, B.S., Field, D.J., Gimona, A., Hedley, C.B., Hong, S.Y., Mandal, B., Marchant, B.P., Martin, M., McConkey, B.G., Mulder, V.L., O’Rourke, S., Richer-de-Forges, A.C., Odeh, I., Padarian, J., Paustian, K., Pan, G., Poggio, L., Savin, I., Stolbovoy, V., Stockmann, U., Sulaeman, Y., Tsui, C.C., Vågen, T.G., Van Wesemael, B., Winowiecki, L., 2017b. Soil carbon 4 per mille. Geoderma 292, 59-86.

Minasny, B., Malone, B.P., McBratney, A.B., Angers, D.A., Arrouays, D., Chambers, A., Winowiecki, L., et al., 2017a. Soil carbon 4 per mille. Geoderma 292, 59-86.

Monroy, F., Aira, M., Domínguez, J., 2011. Epigeic earthworms increase soil arthropod populations during first steps of decomposition of organic matter. Pedobiologia 54, 93-99.

Morriën, E., 2016. Understanding soil food web dynamics, how close do we get? Soil Biol. Biochem. $102,10-13$.

Müller, P.E., 1879. Studier over skovjord: som bidrag til skovdyrkningens teori: om bögemuld og bögemor paa sand og ler. Tidsskrift for Skovbrug 3, 1-124.

Murphy, B., 2010. Greener Pastures on Your Side of the Fence: Better Farming with Voisin Management Intensive Grazing. Arriba Publishing, Colchester.

Mustin, M., 1987. Le Compost: Gestion de la Matière Organique. François Dubusc, Paris.

Nagler, M., Ascher, J., Gómez-Brandón, M., Insam, H., 2016. Soil microbial communities along the route of a venturous cycling trip. Appl. Soil Ecol. 99, 13-18. 
Nebbioso, A., Piccolo, A., 2012. Advances in humeomics: enhanced structural identification of humic molecules after size fractionation of a soil humic acid. Anal. Chim. Acta 720, 77-90.

Nikol'skii, A.A., 2014. Ecological inheritance in the biological signal field of mammals. Russ. J. Ecol. 45, 76-79.

OECD/Food and Agriculture Organization of the United Nations, 2014. OECD-FAO Agricultural Outlook 2014. OECD Publishing, Paris.

Odling-Smee, J.D.H., Erwin, D.H.E.P., Palkovacs, E.P.M.W., Feldman, M.W., Laland, K.N., 2013. Niche construction theory: a practical guide for ecologists. Q. Rev. Biol. 88, 3-28.

Olof, A., Lindberg, T., Boström, U., Clarholm, M., Hansson, A.C., Johansson, G., Lagerlöf, J., Paustian, K., Persson, J., Pettersson, R., Schnürer, J., Sohlenius, B., Wivstad, M., 1990. Organic carbon and nitrogen flows. Ecol. Bull. 40, 85-126.

Palm, C., Blanco-Canqui, H., DeClerck, F., Gatere, L., Grace, P., 2014. Conservation agriculture and ecosystem services: an overview. Agric. Ecosyst. Environ. 187, 87-105.

Paoletti, M.G., 1999. The role of earthworms for assessment of sustainability and as bioindicators. Agr. Ecosyst. Environ. 74, 137-155.

Patten, B.C., 1997. Synthesis of chaos and sustainability in a nonstationary linear dynamic model of the American black bear (Ursus americanus Pallas) in the Adirondack Mountains of New York. Ecol. Modell. 100, 11-42.

Paul, E.A., 2016. The nature and dynamics of soil organic matter: plant inputs, microbial transformations, and organic matter stabilization. Soil Biol. Biochem. 98, 109-126.

Paustian, K., Lehmann, J., Ogle, S., Reay, D., Robertson, G.P., Smith, P., 2016. Climate-smart soils. Nature 532, 49-57.

Pietramellara, G., Ascher, J., Borgogni, F., Ceccherini, M.T., Guerri, G., Nannipieri, P., 2009. Extracellular DNA in soil and sediment: fate and ecological relevance. Biol. Fertil. Soils 45, 219-235.

Pietramellara, G., Ascher, J., Ceccherini, M.T., Nannipieri, P., Wenderoth, D., 2007. Adsorption of pure and dirty bacterial DNA on clay minerals and its transformation frequency. Biol. Fertil. Soils 43, 731-739.

Pietramellara, G., Ceccherini, M.T., Ascher, J., Nannipieri, P., 2006. Persistence of transgenic and not transgenic extracellular DNA in soil and bacterial transformation. Riv. Biol. 99, 37-68.

Pinton, R., Varanini, Z., Nannipieri, P., 2007. The Rhizosphere: Biochemistry and Organic Substances at the Soil-Plant Interface, $2^{\text {nd }}$ ed. CRC Press, Boca Raton.

Ponge, J.F., 2015. The soil as an ecosystem. Biol. Fertil. Soils 51, 645-648.

Prashar, P., Shah, S., 2016. Impact of fertilizers and pesticides on soil microflora in agriculture. In: Lichtfouse, E. (Ed.), Sustainable Agriculture Reviews, vol. 19. Springer, Cham, pp. 331-361. 
Pugesgaard, S., Schelde, K., Larsen, S.U., Lærke, P.E., Jørgensen, U., 2015. Comparing annual and perennial crops for bioenergy production-influence on nitrate leaching and energy balance. GCB Bioenergy 7, 1136-1149.

Pugin, A., 1991. Glacial sedimentary sequences in Seeland and Mittelland (Switzerland). Ecl. Geol. Helv. 84, 177-206.

Querner, E.P., Jansen, P.C., van den Akker, J.J.H., Kwakernaak, C., 2012. Analysing water level strategies to reduce soil subsidence in Dutch peat meadows. J. Hydrol. 446/447, 59-69.

Rahmani, M., Hodges, A., Kiker, C., 2004. Compost users' attitudes toward compost application in Florida. Compost. Sci. Util. 12, 55-60.

Ranjard, L., Richaume, A., 2001. Quantitative and qualitative microscale distribution of bacteria in soil. Res. Microbiol. 152, 707-716.

Rovira, A.D., 1969. Plant root exudates. Bot. Rev. 35, 35-57.

Sánchez-de León, Y., Lugo-Pérez, J., Wise, D.H., Jastrow, J.G., González-Meler, M.A., 2014. Aggregate formation and carbon sequestration by earthworms in soil from a temperate forest exposed to elevated atmospheric $\mathrm{CO}_{2}$ : a microcosm experiment. Soil Biol. Biochem. 68, 223-230.

Saha, D., Kukal, S.S., Bawa, S.S., 2014. Soil organic carbon stock and fractions in relation to land use and soil depth in the degraded Shiwaliks hills of lower Himalayas. Land Degrad. Dev. 25, 407416.

Saha, D., Kukal, S.S., Sharma, S., 2011. Land use impacts on SOC fractions and aggregate stability in Typic Ustochrepts of Northwest India. Plant Soil 339, 457-470.

Salmon, S., 2004. The impact of earthworms on the abundance of Collembola: improvement of food resources or of habitat? Biol. Fertil. Soils 40, 323-333.

Savory, A., Butterfield, J., 1999. Holistic Management: A New Framework for Decision Making. Island Press, Washington, D.C.

Savory, A., Butterfield, J., 2016. Holistic Management, $3^{\text {rd }}$ ed. A Commonsense Revolution to Restore our Environment. Island Press, Washington, D.C.

Scheu, S., 2002. The soil food web: structure and perspectives. Eur. J. Soil Biol. 38, 11-20.

Schipanski, M.E., Barbercheck, M., Douglas, M.R., Finney, D.M., Haider, K., Kaye, J.P., Kemanian, A.R., Mortensen, D.A., Ryan, M.R., Tooker, J., White, C., 2014. A framework for evaluating ecosystem services provided by cover crops in agroecosystems. Agric. Syst. 125, 12-22.

Schlesinger, W.H., 2000. Carbon sequestration in soils: some cautions amidst optimism. Agric. Ecosyst. Environ. 82, 121-127.

Schmidt, M.W.I., Torn, M.S., Abiven, S., Dittmar, T., Guggenberger, G., Janssens, I.A., Kleber, M., Kogel-Knabner, I., Lehmann, J., Manning, D.A.C., Nannipieri, P., Rasse, D.P., Weiner, S., 
Trumbore, S.E., 2011. Persistence of soil organic matter as an ecosystem property. Nature $478,49-56$.

Scott, D., Markewitz, D., Hendrix, P., Coleman, D., 2014. Soil aggregates and associated organic matter under conventional tillage no-tillage, and forest succession after three decades. PLoS ONE 9, e84988.

Sechi, V., De Goede, R.G.M., Rutgers, M., Brussaard, L., Mulder, C., 2017. A community trait-based approach to ecosystem functioning in soil. Agric. Ecosyst. Environ. 239, 265-273.

Smil, V., 1999. Crop residues: agriculture's largest harvest: crop residues incorporate more than half of the world's agricultural phytomass. BioScience 49, 299-308.

Smith, J., Smith, P., Wattenbach, M., Zaehle, S., Hiederer, R., Jones, R.J.A., Montanarella, L., Rounsevell, M.D.A., Reginster, I., Ewert, F., 2005. Projected changes in mineral soil carbon of European croplands and grasslands, 1990-2080. Global Change Biol. 11, 2141-2152.

Soil Health, 2016. Soil Health. http://www.soilhealth.com.

Spaccini, R., Piccolo, A., Conte, P., Haberhauer, G., Gerzabek, M.H., 2002. Increased soil organic carbon sequestration through hydrophobic protection by humic substances. Soil Biol. Biochem. 34, 1839-1851.

Spohn, M., Giani, L., 2010. Water-stable aggregates, glomalin-related soil protein, and carbohydrates in a chronosequence of sandy hydromorphic soils. Soil Biol. Biochem. 42, 1505-1511.

Spohn, M., Klaus, K., Wanek, W., Richter, A., 2016. Microbial carbon use efficiency and biomass turnover times depending on soil depth: implications for carbon cycling. Soil Biol. Biochem. $96,74-81$.

Stevenson, F.J., 1994. Humus Chemistry: Genesis, Composition, Reactions. John Wiley and Sons, Hoboken.

Stockmann, U., Adams, M.A., Crawford, J.W., Field, D.J., Henakaarchchi, N., Jenkins, M., Zimmermann, M., et al., 2013. The knowns, known unknowns and unknowns of sequestration of soil organic carbon. Agric. Ecosyst. Environ. 164, 80-99.

Stockmann, U., Padarian, J., McBratney, A., Minasny, B., de Brogniez, D., Montanarella, L., Hong, S.Y., Rawlins, B.G., Field, D.J., 2015. Global soil organic carbon assessment. Global Food Secur. 6, 9-16.

Streets, D.G., Yarber, K.F., Woo, J.H., Carmichael, G.R., 2003. An Inventory of Gaseous and Primary Aerosol Emissions in Asia in the Year 2000. J. Geophys. Res. 108, 8809-8823.

Sutton, R., Sposito, G., 2005. Critical review molecular structure in soil humic substances: the new view. Environ. Sci. Technol. 39, 9009-9015.

Taylor, J.P., Wilson, B., Mills, M.S., Burns, R.G., 2002. Comparison of microbial numbers and enzymatic activities in surface soils and subsoils various techniques. Soil Biol. Biochem. 34 , 387-401. 
Tonks, A.J., Aplin, P., Beriro, D.J., Cooper, H., Evers, S., Vane, C.H., Sjogersten, S., 2017. Impacts of conversion of tropical peat swamp forest to oil palm plantation on peat organic chemistry, physical properties and carbon stocks. Geoderma 289, 36-45.

Ursell, L.K., Metcalf, J.L., Parfrey, L.W., Knight, R., 2012. Defining the human microbiome. Nutr. Rev. 70, S38-S44.

Van der Wal, A., De Boer, W., 2017. Dinner in the dark: illuminating drivers of soil organic matter decomposition. Soil Biol. Biochem. 105, 45-48.

Verhulst, N., Cox, R., Govaerts, B., 2013. Soil Aggregate Stability by Wet Sieving: A Practical Guide for Comparing Crop Management Practices. CIMMYT, Mexico, DF.

Wösten, J.H.M., Ismail, A.B., van Wijk, A.L.M., 1997. Peat subsidence and its practical implications: a case study in Malaysia. Geoderma 78, 25-36.

Wade, M.J., 1977. An experimental study of group selection. Evolution 31, 134-153.

Wamelink, G.W.W., Frissel, J.Y., Krijnen, W.H.J., Verwoert, M.R., Goedhart, P.W., 2014. Can plants grow on Mars and the Moon: a growth experiment on Mars and Moon soil simulants. PLoS ONE 9, e103138.

Wasak, K., Drewnik, M., 2015. Land use effects on soil organic carbon sequestration in calcareous Leptosols in former pastureland: a case study from the Tatra Mountains (Poland). Solid Earth 6, 1103-1115.

Weir, A., 2011. The Martian. Del Rey, New York.

West, T.O., Post, W.M., 2002. Soil organic carbon sequestration rates by tillage and crop rotation. Soil Sci. Soc. Am. J. 66, 1930-1946.

Wheeler, I., 2014. The Auditability of Soil Carbon at the Farm Scale. PhD Thesis, University of Sydney, Sydney.

Whitford, W.G., 2000. Keystone arthropods as webmasters in desert ecosystems. In: Coleman, D.C., Hendrix, P.F. (Eds.), Invertebrates as Webmasters in Ecosystems. CAB International, Wallingford, pp. 25-41.

Wickenbrock, L., Heisler, C., 1997. Influence of earthworm activity on the abundance of Collembola in soil. Soil Biol. Biochem. 29, 517-521.

Wieland, G., Neumann, R., Backhaus, H., 2001. Variation of microbial communities in soil, rhizosphere, and rhizoplane in response to crop species, soil type, and crop development. Appl. Environ. Microbiol. 67, 5849-5854.

Wilson, D.S., Wilson, E.O., 2008. Evolution 'for the good of the group'. Am. Sci. 96, 380-389.

Wise, D.H., Snyder, W.E., Tuntibunpakul, P., Halaj, J., 1999. Spiders in decomposition food webs of agroecosystems: theory and evidence. J. Arachnol. 27, 363-370. 
Xie, J., Hou, M., Zhou, Y., Wang, R., Zhang, S., Yang, X., Sun, B., 2017. Carbon sequestration and mineralization of aggregate-associated carbon in an intensively cultivated Anthrosol in North China as affected by long term fertilization. Geoderma 296, 1-9.

Yoder, R.E., 1936. A direct method of aggregate size analysis of soils and a study of the physical nature of erosion losses. J. Am. Soc. Agron. 28, 337-351.

Zhang, T., Wooster, M.J., Green, D.C., Main, B., 2015. New field-based agricultural biomass burning trace gas, PM2.5, and black carbon emission ratios and factors measured in situ at crop residue fires in Eastern China. Atmospheric Environment 121, 22-34. 


\section{Figure captions}

Fig. 1. Humipedon, Copedon and Lithopedon, three relatively independent parts of a soil profile in aerated a) natural and b) anthropogenic soils; aboveground ecosystem with its pluricellular and unicellular organisms: c) bottom-up transfers; d) Internal homogenization: e) bottom-up transfers.

Fig. 2. Matt Damon in "The Martian", a 2015 science fiction film directed by Ridley Scott and based on Andy Weir's 2011 novel of the same name. The astronaut survived by producing potatoes in a Martian sand mixed with human faeces.

Fig. 3. a) Masanobu Fukuoka at age 62 (Japanese, 2 February, 1913 - 16 August, 2008). Author of the photograph: Larry Korn, in The One-Straw Revolution: http://www.onestrawrevolution.net/One Straw Revolution/Massanobu Fukuoka.html; b) Place of Fukuoka's family farmlands, now farmed in a modern, conventional manner. Author of the photograph: lyo-farm, 11 February 2011 (Creative Commons licence). Photo gallery of the original Masanobu Fukuoka's farm at:

http://www.onestrawrevolution.net/One Straw Revolution/Photos Galleries/Pages/Fukuok a Farm.html\#grid.

Fig. 4. a) and b) Soil structure made by anecic earthworms inhabiting and continuously re-elaborating the soil under the lawn of the Campus of Agripolis (University of Padue, Legnaro, Italy). Soil structures in sub-tropical arid grasslands (South-Africa): c) Vertical section in herbivorous dung showing arthropod droppings, fungal hyphae, animal tunnels, etc.); d) millipede at the bottom of the dung, many coleopteran larvae within the mass and at the bottom of the manure; a real organic-mineral A horizon is generated under the dung; e) termite tunnels full of meso organic-mineral aggregates, in an otherwise massive abiotic piece of soil; $f$ ) and $g$ ) meso organic-mineral aggregates generated by ants.

Fig. 5. Variation of SOC in different WSA sizes under different land uses (adapted from Saha et al., 2014).

Fig. 6. SOC stock ( $\mathrm{Mg} \mathrm{ha}^{-1}$ ) in the top $15 \mathrm{~cm}$ soil layer under different land uses (modified from Saha et al., 2014).

Fig. 7. Relationship between water stable aggregates (WSA $>0.25 \mathrm{~mm}$ ) and SOC stock (adapted from Saha et al., 2014).

Fig. 8. September's average price of corn from 2004 to 2016. Source: Chamber of commerce of Bologna. In the optimistic scenario, the price utilized for corn is the average monthly price of September for the period 2004-2016, equal to $176 € / \mathrm{t}$.

Fig. 9. Comparison between the yield of corn calculated at the breakeven point and the average yield obtained in the experimental field of Ceregnano.

Fig. 10. Realistic scenarios: comparison of gross margins calculated with and without public regional subsidies. 
Fig. 11. Carbon sequestration rates. a) scenario 1 , with a saturation point at $1.4 \%$ of SOC, corresponding to $78 \mathrm{t} / \mathrm{ha}$; b) scenario 2 with a saturation point at $2.4 \%$ of SOC corresponding to $134 \mathrm{t} / \mathrm{ha}$. Experiments conducted in Ceregnano during 5 years showed an annual SOC storage capacity of about $2.1 \mathrm{t} / \mathrm{ha} / \mathrm{y}$ in plots under MT and of $3.2 \mathrm{t} / \mathrm{ha} / \mathrm{y}$ in NT ones. Linearly applied, these experimental values of annual storage bring SOC from $1 \%$ (measured $56 \mathrm{t} / \mathrm{ha}$ ) to $1.4 \%$ (point of saturation estimated at $78.4 \mathrm{t} /$ ha, scenario 1 ) and from 1 to $2.4 \%$ (saturation at $134 \mathrm{t} / \mathrm{ha}$, scenario 2 ).

Fig. 12. Rarefaction of peat material. a) pylon installed on a drained wetland; b) same pylon few years later, clearly showing a decrease in soil thickness (photographs: H.P. Käser).

Fig. 13. Relative sizes of global carbon pools (from Wheeler, 2014).

Fig. 14. Global soil $C$ sequestration rate (tonnes of $C$ per ha per year) to achieve the 4 per 1000 initiative. The map was generated based on global datasets of $C$ stock from the study of Stockmann et al. (2015).

Fig. 15. Interactions between scientists, farmers, policy makers, and marketers engaged in implementation of the 4 per 1000 soil C initiative (from Minasny et al., 2017a and b).

Fig. 16. Is Homo sapiens intelligent enough? a) Homo sapiens is not very intelligent; b) Homo sapiens is rather intelligent. Source of map of human migration:

https://commons.wikimedia.org/wiki/File:Map-of-human-migrations.jpg. 


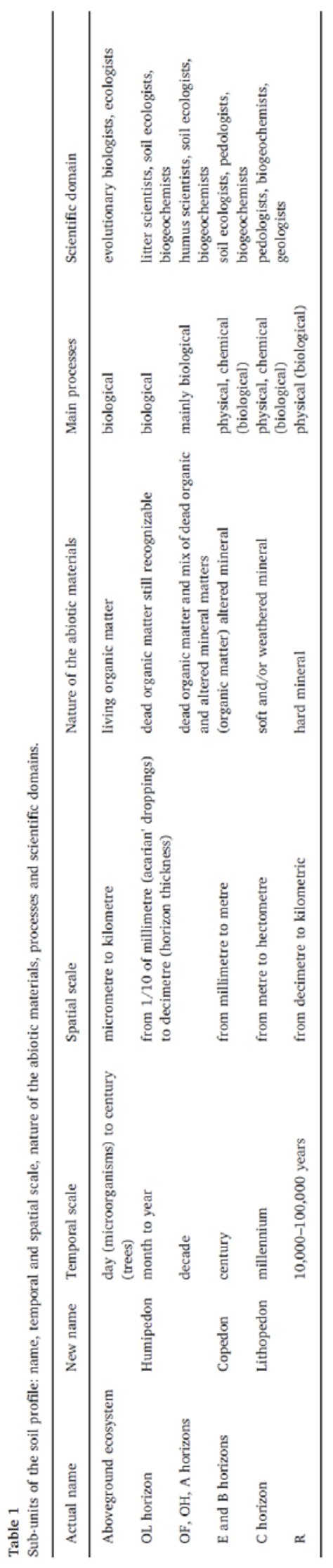


Table 2

Comparison of direct cost of corn ( $€ / h a)$.

\begin{tabular}{llll}
\hline Cost & Conventional & $\begin{array}{l}\text { Minimum } \\
\text { tillage }\end{array}$ & No tillage \\
\hline Plowing & 150 & 0 & 0 \\
Grubbing & 50 & 0 & 0 \\
Coltivator of MT & 0 & 120 & 0 \\
Fertilization pre sowing & 290 & 290 & 290 \\
Grubbing (2 steps) & 75 & 0 & 0 \\
Sowing with localized & 320 & 320 & 390 \\
$\quad$ & & \\
$\quad$ fertilization & 120 & 120 & 120 \\
Weeding pre emergency & 110 & 110 & 110 \\
Hoeing with fertilization & 310 & 310 & 240 (fertilization \\
& & & only) \\
Treatment corn borer & 80 & 80 & 80 \\
Threshing with stalk & 140 & 140 & 140 \\
$\quad$ shredder & 70 & 70 & 70 \\
Trasport & 0 & 40 & 40 \\
Soil analysis & 1715 & 1600 & 1480 \\
Total & & & \\
\hline
\end{tabular}


Table 3

Gross margin obtained with corn in conventional, minimum tillage and no tillage ( $€ / \mathrm{ha})$.

\begin{tabular}{lllll}
\hline Crop & Variable & Conventional & Minimum tillage & No tillage \\
\hline \multirow{2}{*}{ corn } & Gross production & 1845,9 & 1464,7 & 1083,5 \\
& Direct cost & 1715 & 1540 & 1500 \\
\multirow{4}{*}{ wheat } & Gross Margin & 130,9 & $-75,3$ & $-416,5$ \\
& Gross production & 1269 & 1269 & 1225 \\
& Direct cost & 970 & 910 & 890 \\
\multirow{5}{*}{ soy beans } & Gross Margin & 299 & 359 & 335 \\
& Gross production & 1581 & 1455 & 1178 \\
& Direct cost & 890 & 815 & 705 \\
& Gross Margin & 691 & 640 & 474 \\
\hline
\end{tabular}


Table 4

Yearly average gross margin per hectare with conventional, minimum tillage and no tillage

\begin{tabular}{|c|c|c|c|c|c|c|}
\hline Soil use & Year & Crop & Gross production $(€ /$ ha) & Cost of cultivation $(€ /$ ha) & $\begin{array}{l}\text { Cost cover crops } \\
(€ / \text { ha) }\end{array}$ & Gross Margin $(€ / \mathrm{ha})$ \\
\hline \multirow[t]{7}{*}{ Conventional } & 1 & wheat & 1270 & 970 & 0 & 300 \\
\hline & 2 & Corn & 1846 & 1715 & 0 & 131 \\
\hline & 3 & Soy & 1582 & 890 & 0 & 692 \\
\hline & 4 & corn & 1846 & 1715 & 0 & 131 \\
\hline & 5 & corn & 1846 & 1715 & 0 & 131 \\
\hline & Tot. & & & & & 1.384 \\
\hline & Average Gross margin per year & & & & & 277 \\
\hline \multirow[t]{8}{*}{ Minimum tillage } & 1 & wheat & 1270 & 910 & 0 & 359,5 \\
\hline & 2 & Corn + cover crops & 1465 & 1600 & 210 & $-345,33$ \\
\hline & 3 & Soy + cover crops & 1455 & 815 & 210 & 430,21 \\
\hline & 4 & Wheat & 1270 & 910 & 0 & 359,5 \\
\hline & 5 & corn + cover crops & 1465 & 1600 & 210 & $-345,33$ \\
\hline & Tot. & & & & & 458,56 \\
\hline & $\begin{array}{l}\text { Gross margin/year without } \\
\text { subsidies }\end{array}$ & & & & & 91,7 \\
\hline & Gross margin/year with subsidies & & & & & 417 \\
\hline \multirow[t]{8}{*}{ No tillage } & 1 & wheat & 1226 & 890 & 0 & 336 \\
\hline & 2 & Corn + cover crops & 1083 & 1480 & 210 & -607 \\
\hline & 3 & Soy + cover crops & 1179 & 705 & 210 & 264 \\
\hline & 4 & Wheat & 1226 & 890 & 0 & 336 \\
\hline & 5 & corn + cover crops & 1083 & 1480 & 210 & -607 \\
\hline & Tot. & & & & & -278 \\
\hline & $\begin{array}{l}\text { Gross margin/year without } \\
\text { subsides }\end{array}$ & & & & & -56 \\
\hline & Gross margin/year with subsides & & & & & 488 \\
\hline
\end{tabular}


Table 5

Annual SOC storage and perceived subsides per SOC and $\mathrm{CO}_{2}(=\mathrm{SOC} / 3.66)$ tons.

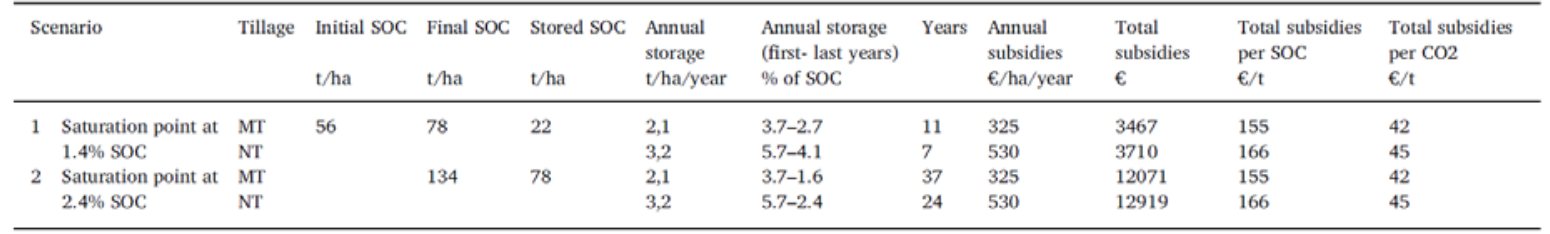


Table 6

Costs of different C storage technologies. Legend: \# Life Carbomark data (http://ec. europa.eu/environment/life/project/Projects/index.cfm? fuseaction = search.dspPage\&n_ proj_id=3269); \#\# ICO2N data (http://www.zeroco2.no/projects/developers/ico2n).

Storage type

Forest management

Conservative Agriculture

Woody manufacture

Urban afforestation

CCS (Carbon Capture and Storage)
Price range $(€ / \mathrm{t} \mathrm{CO} 2)$

$$
\begin{aligned}
& \text { 4-13\# } \\
& 42-45 \\
& 20-60 \# \# \\
& 30-80 \# \\
& 113-132 \# \#
\end{aligned}
$$


Table 7

The average soil C sequestration rates for topsoil reported from a meta-analysis by Lam et al. (2013).

\begin{tabular}{lllll}
\hline Practices & Sequestration rates & N & Mean & Std. dev \\
\hline Reduced tillage & \%C year & & \\
Residue management & \%C year & & 0.016 & 0.023 \\
Pasture & \%C year & & 0.022 & 0.043 \\
Reduced tillage & Mg C ha $^{-1}$ year $^{-1}$ & 62 & 0.215 & 0.299 \\
Residue management & Mg C ha $^{-1}$ year $^{-1}$ & 36 & 0.152 & 0.330 \\
Pasture & Mg C ha $^{-1}$ year $^{-1}$ & 42 & 0.146 & 0.405 \\
Reduced tillage & Per mille year & & \\
Residue management & Per mille year & & & \\
Pasture & Per mille year & 36 & 9.3 & 12.6 \\
& & 42 & 10.9 & 23.9 \\
\hline
\end{tabular}


a) AERATED SOILS

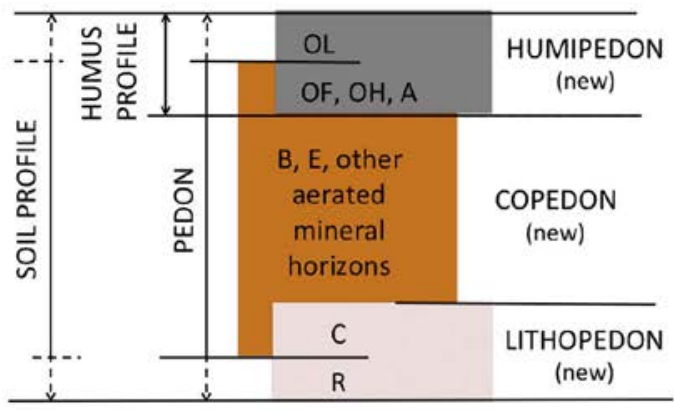

c)

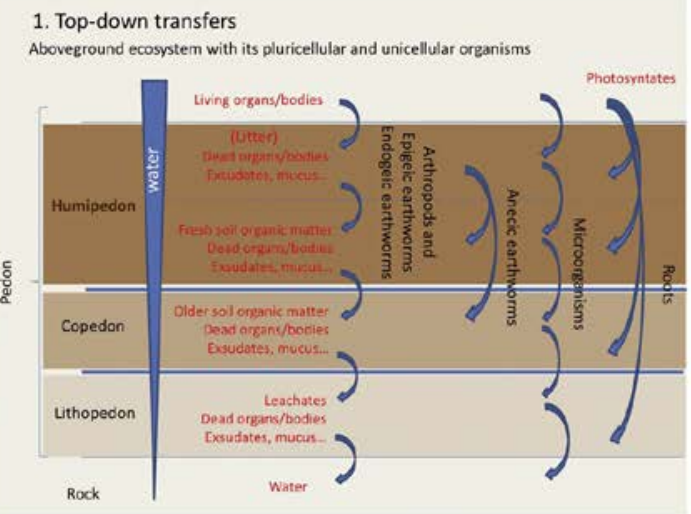

b) AERATED ANTHROPOGENIC SOILS

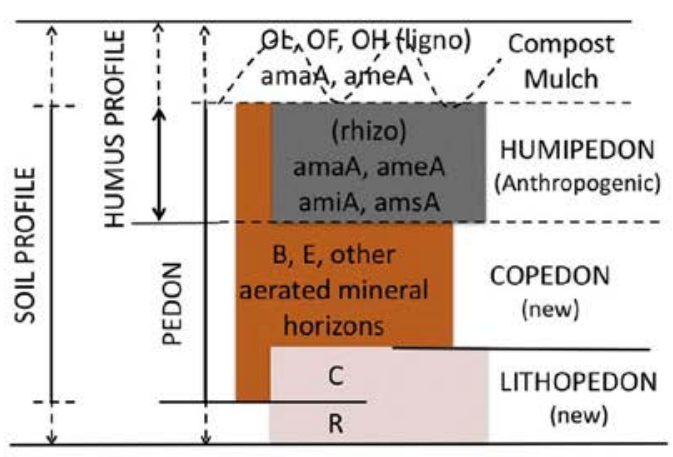

d)

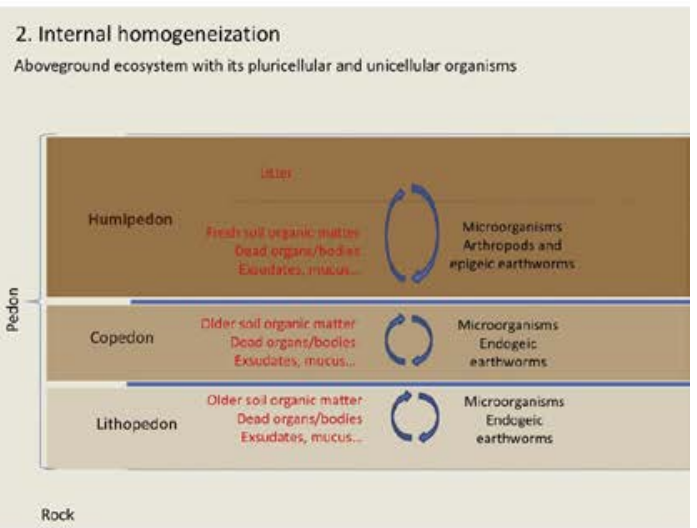

e)

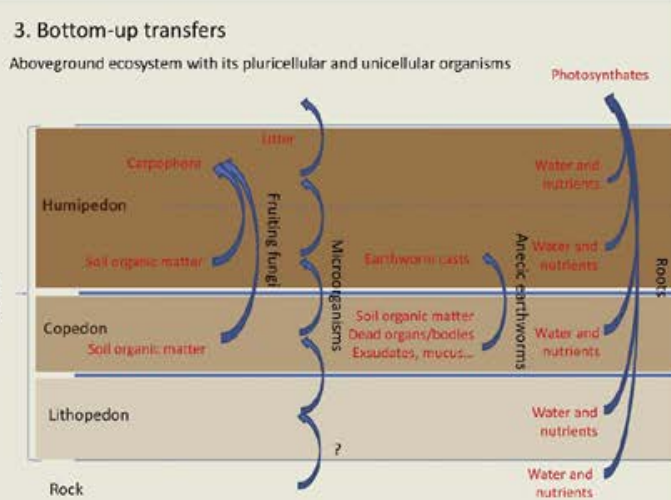

Fig. 1 


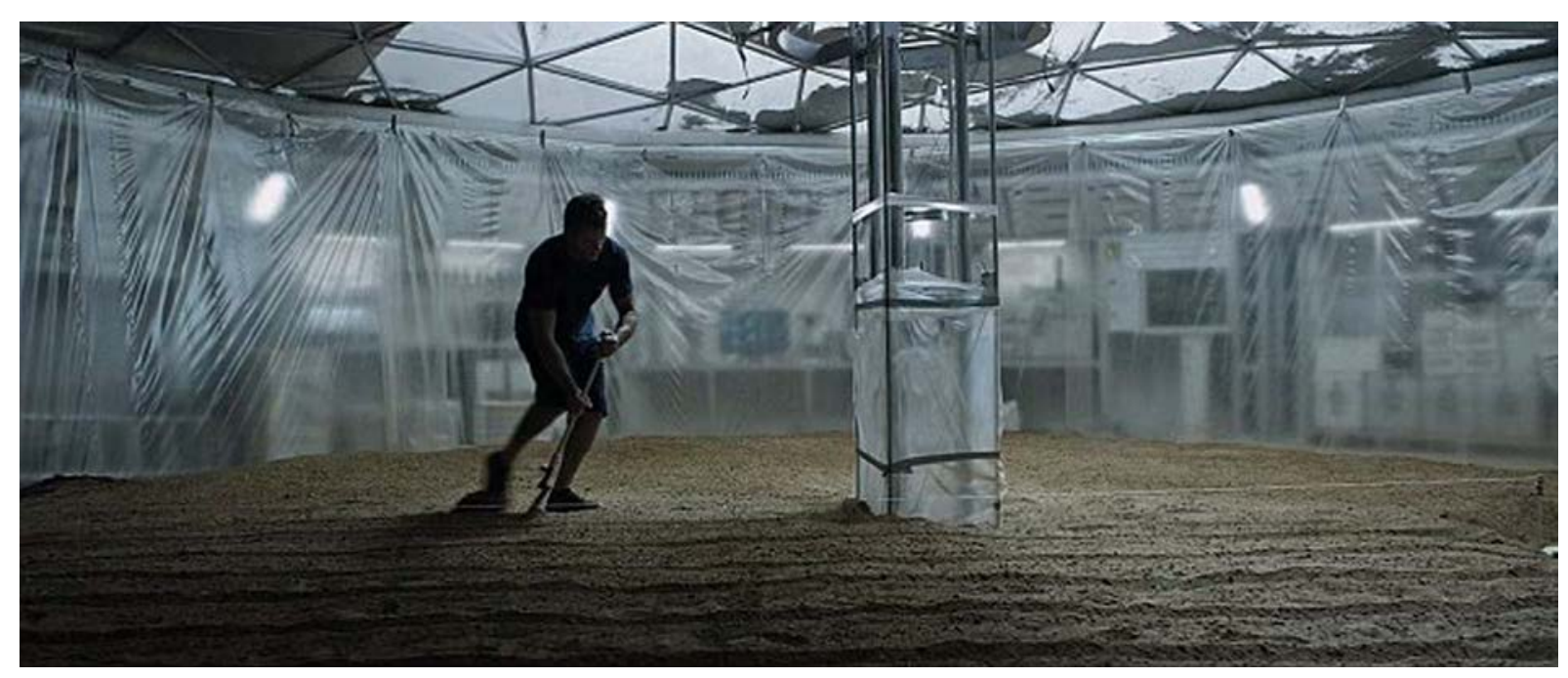

Fig. 2 
a)

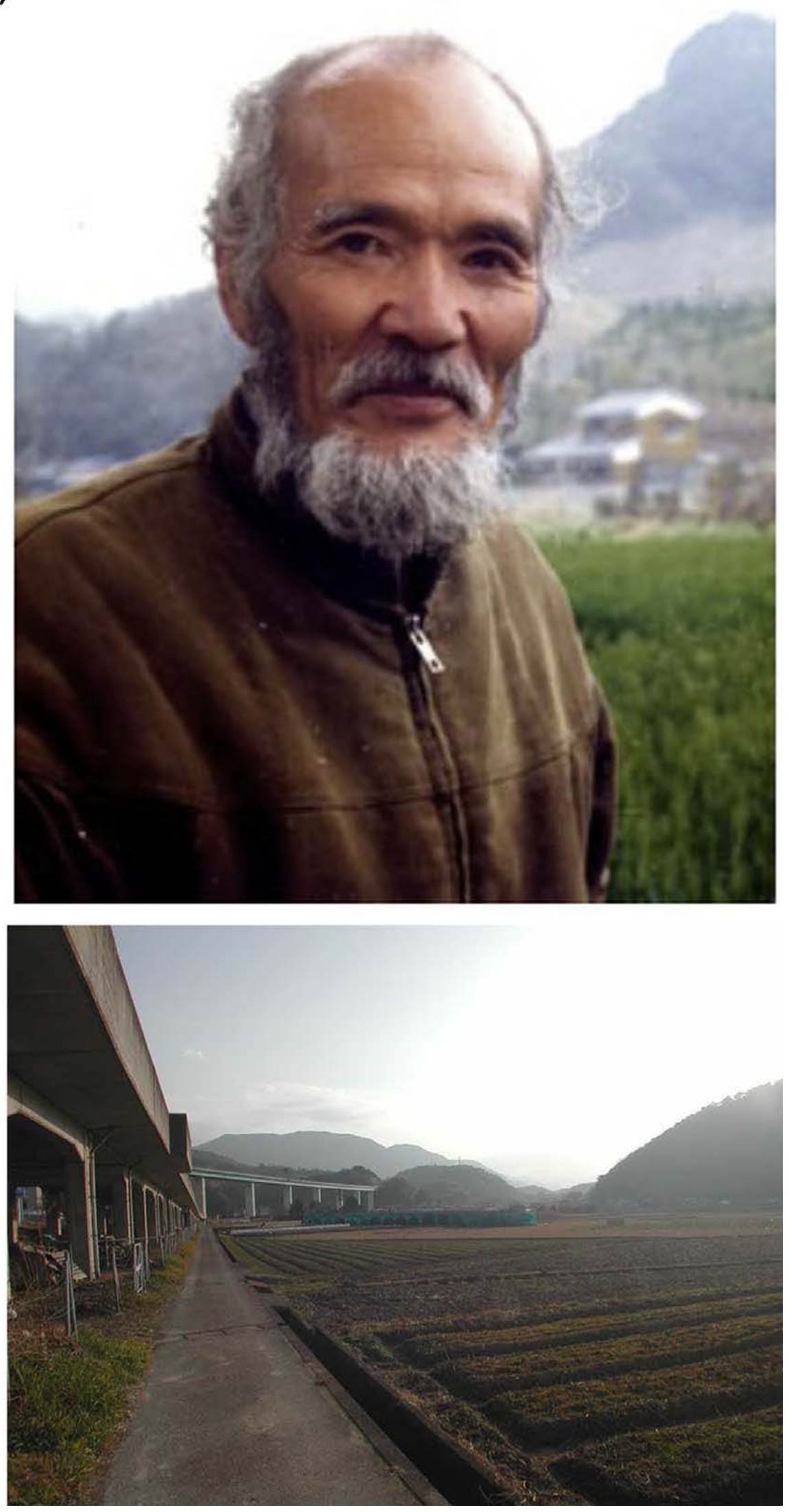

Fig. 3 
a)

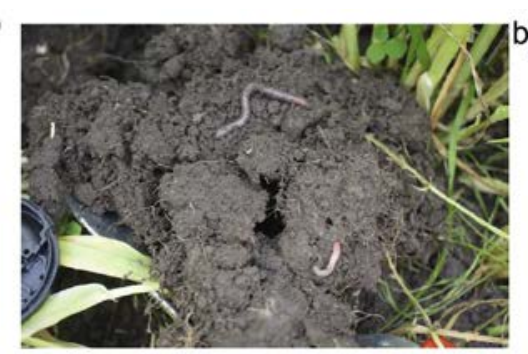

d)
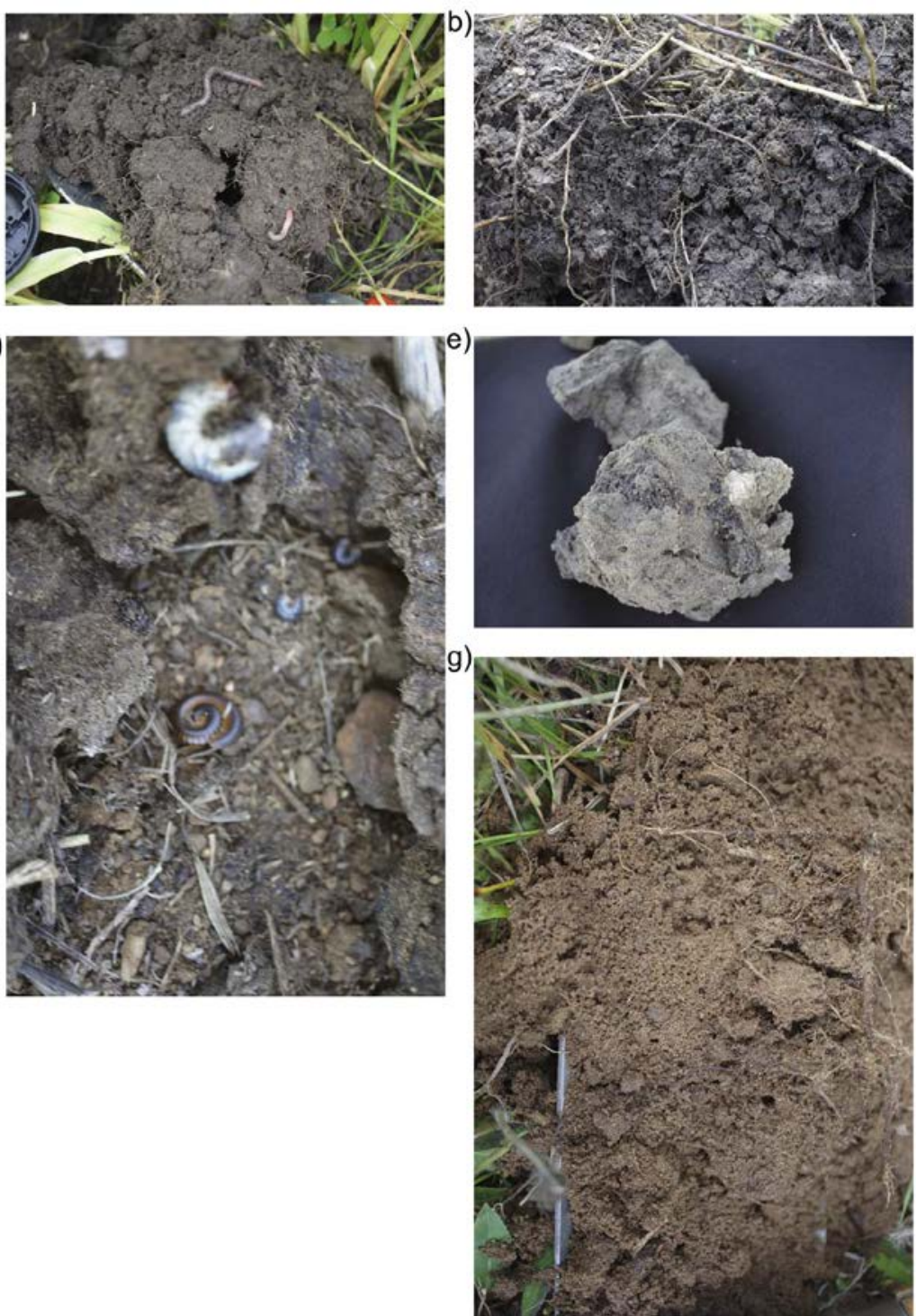
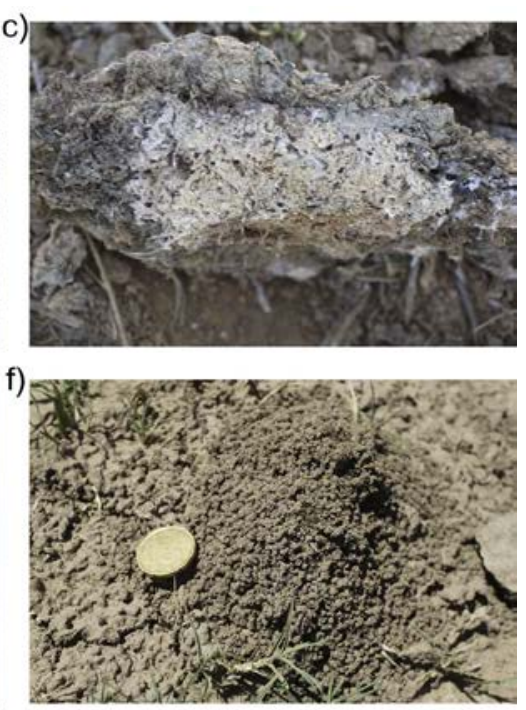

Fig. 4 


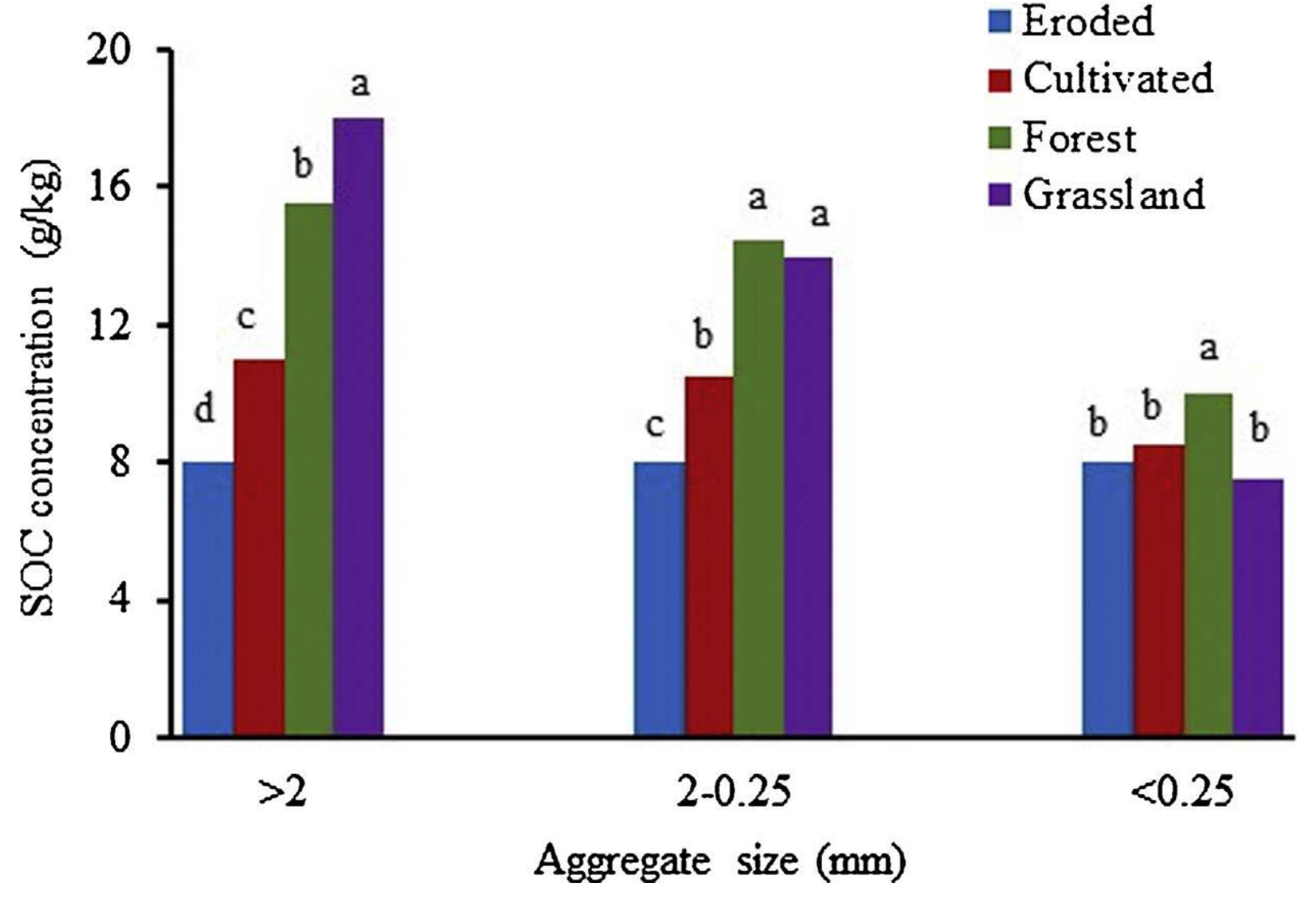

Fig. 5 


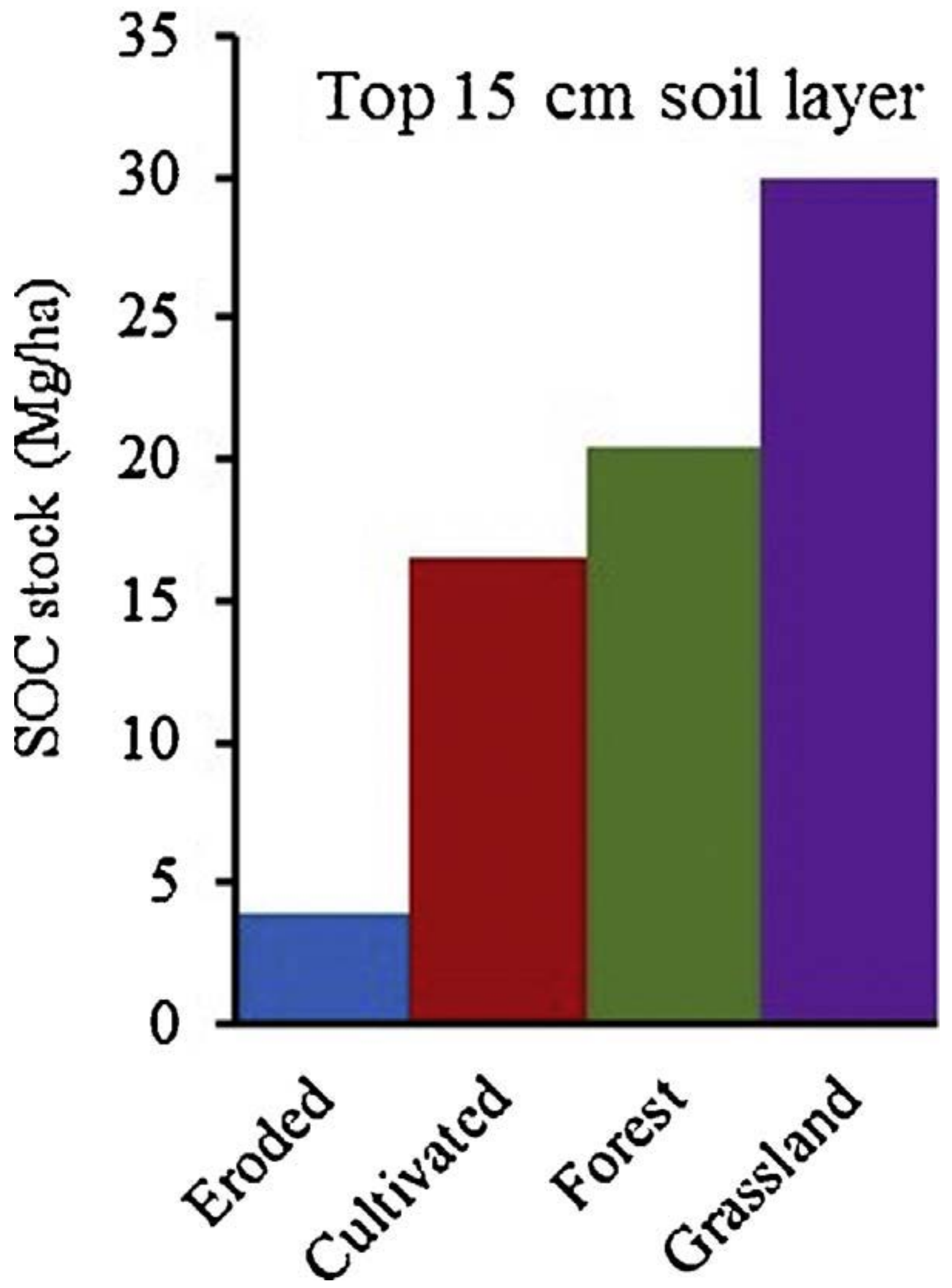

Fig. 6 


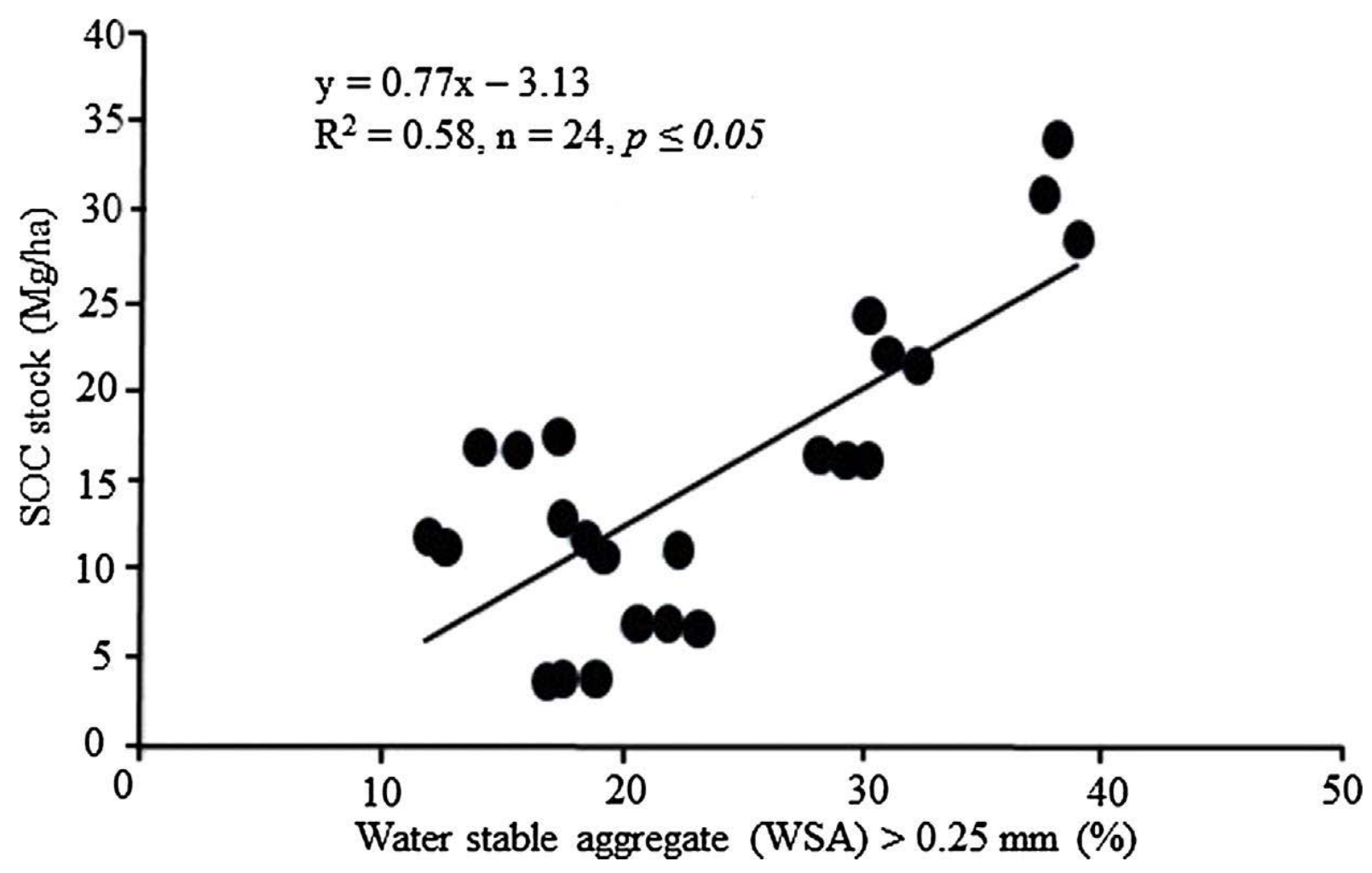

Fig. 7 
300

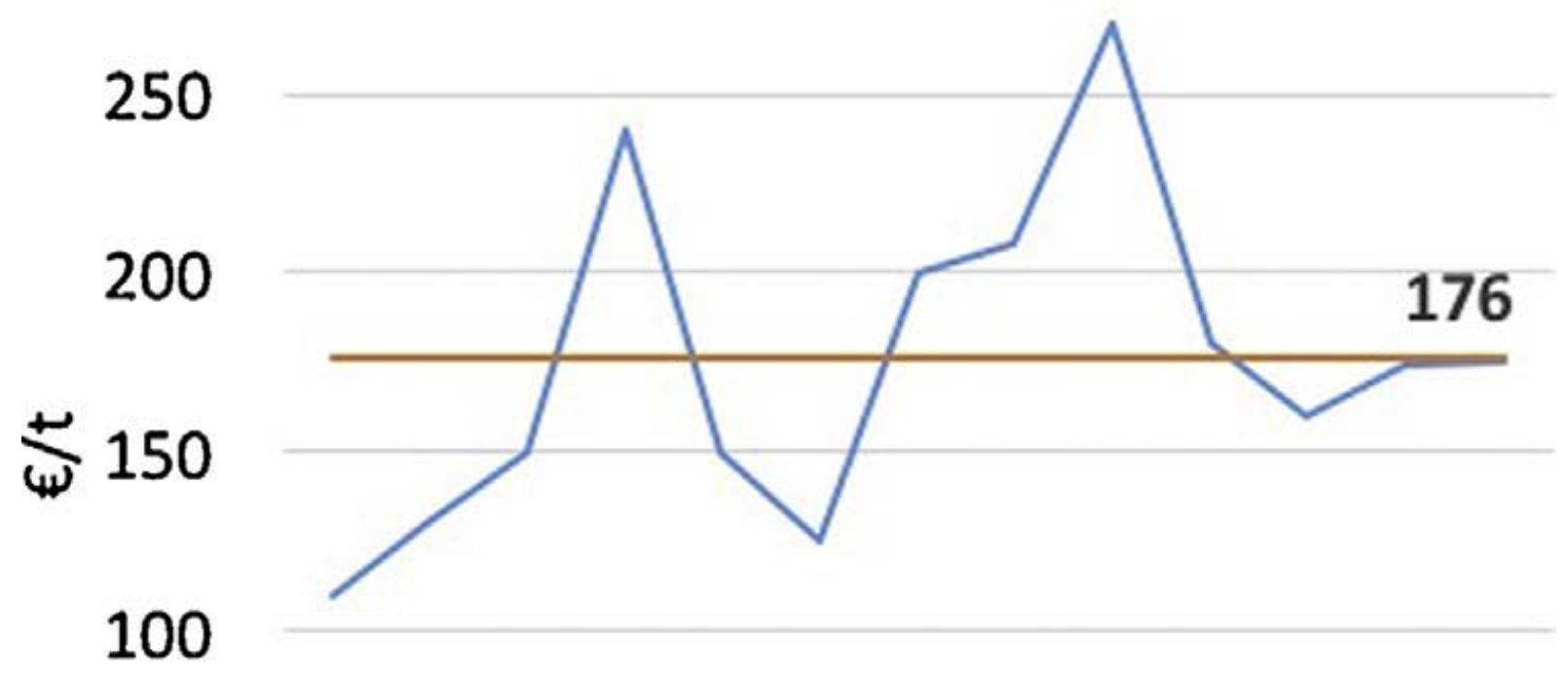

50

0

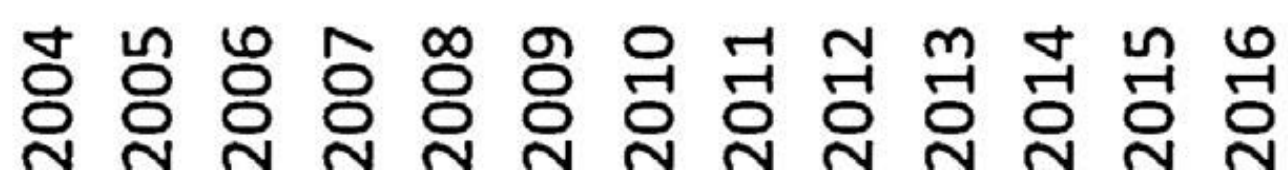

Fig. 8 


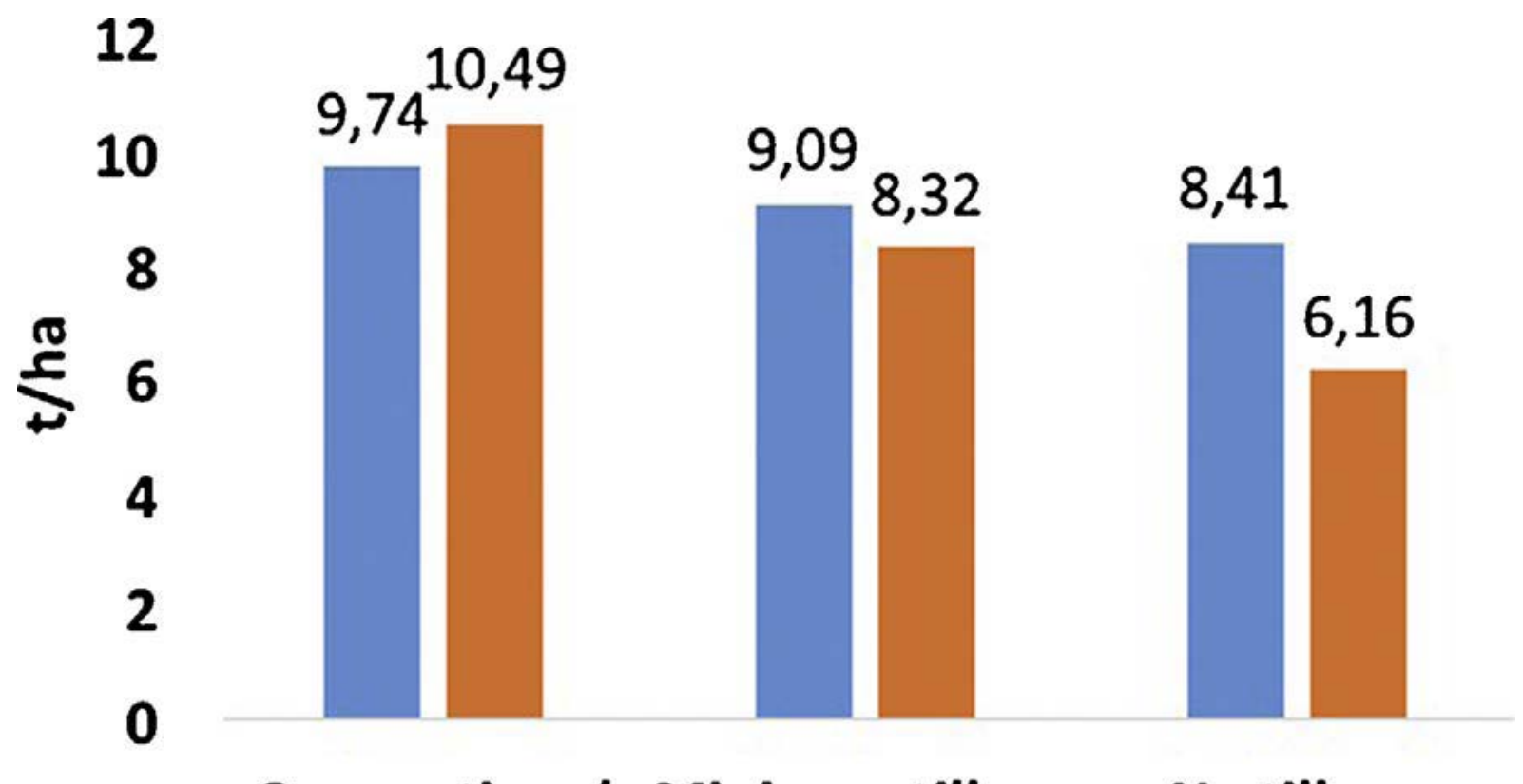

Conventional Minimun tillage No tillage

Average yields in Ceregnano

Yields at the break even point

Fig. 9 
400

300

292,5

200

193,6

100

0

$44,9 \quad 44,9$

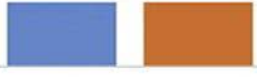

\section{Conventional}

$-100$

$-200$

$-131,4$

$-300$

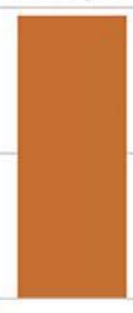


a) 140

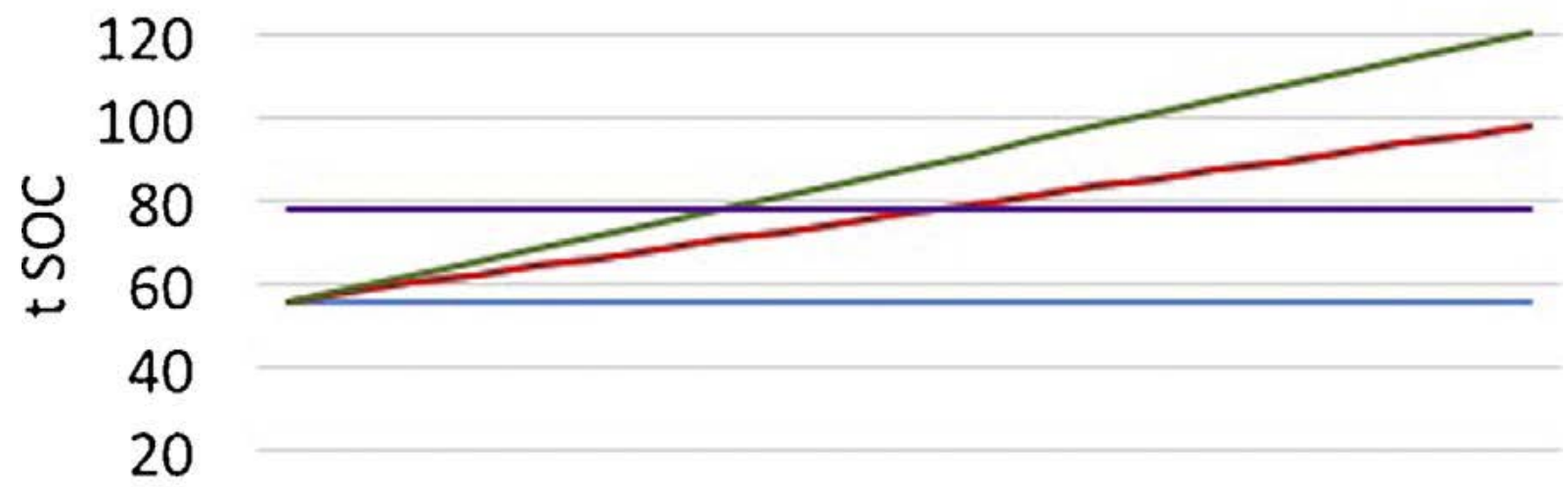

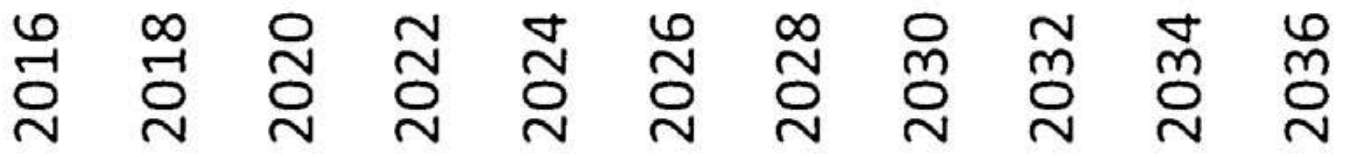

b) - Conventional - $\mathrm{MT}-\mathrm{NT}-\mathrm{SOC} \max$

250

200
$\stackrel{ }{ } 150$
$\stackrel{\sim}{\sim} 100$

50

0

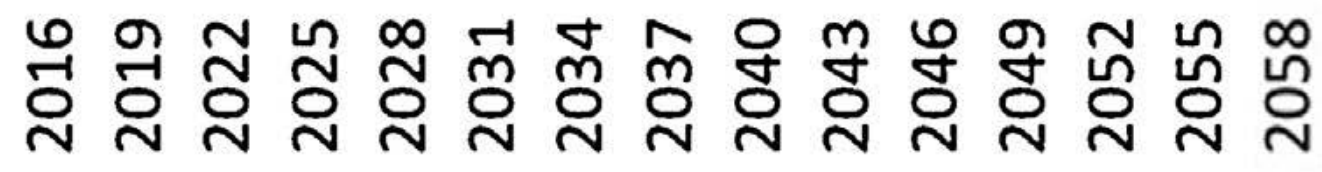

- Conventional - MT -NT - SOC max

Fig. 11 
a)

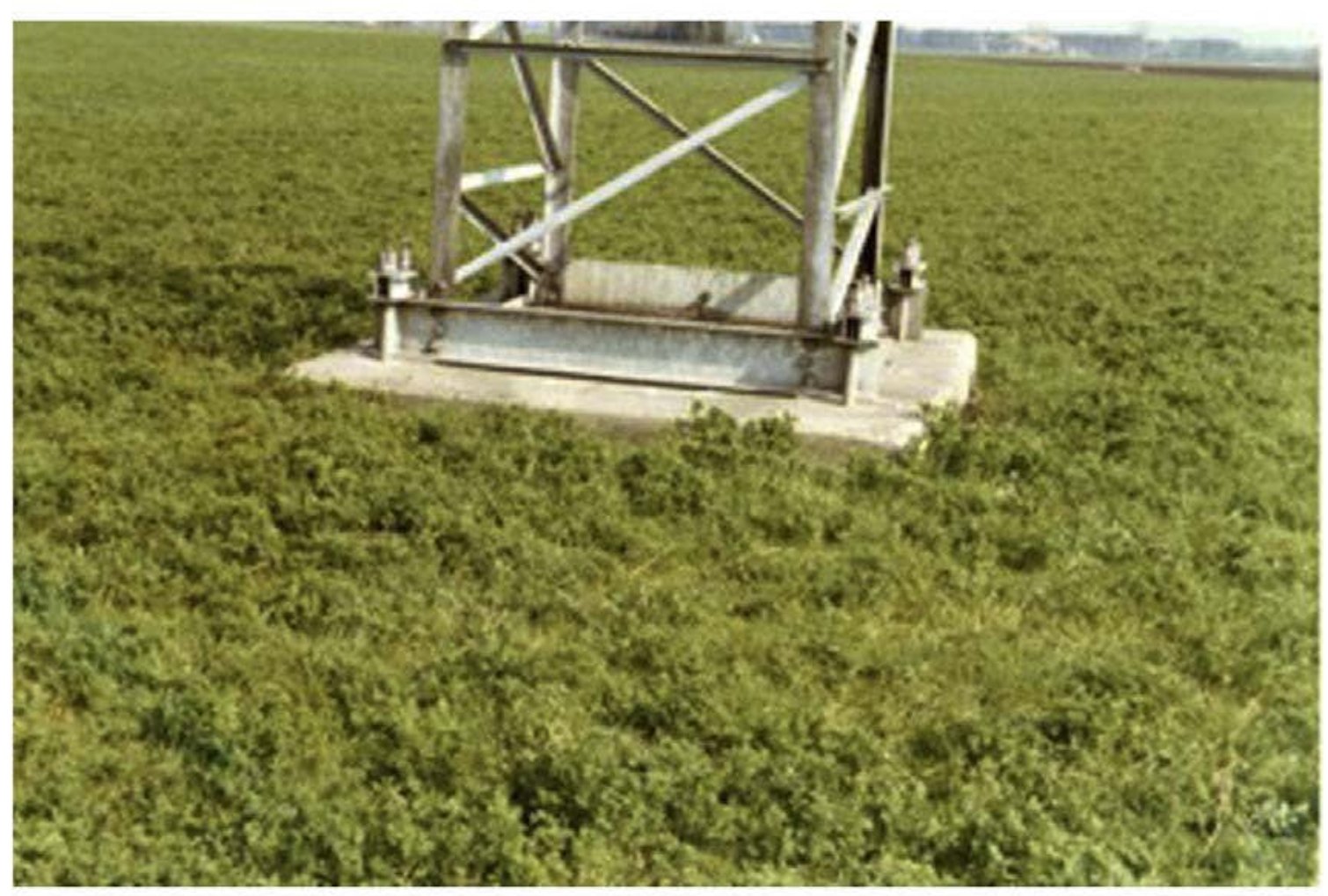

b)

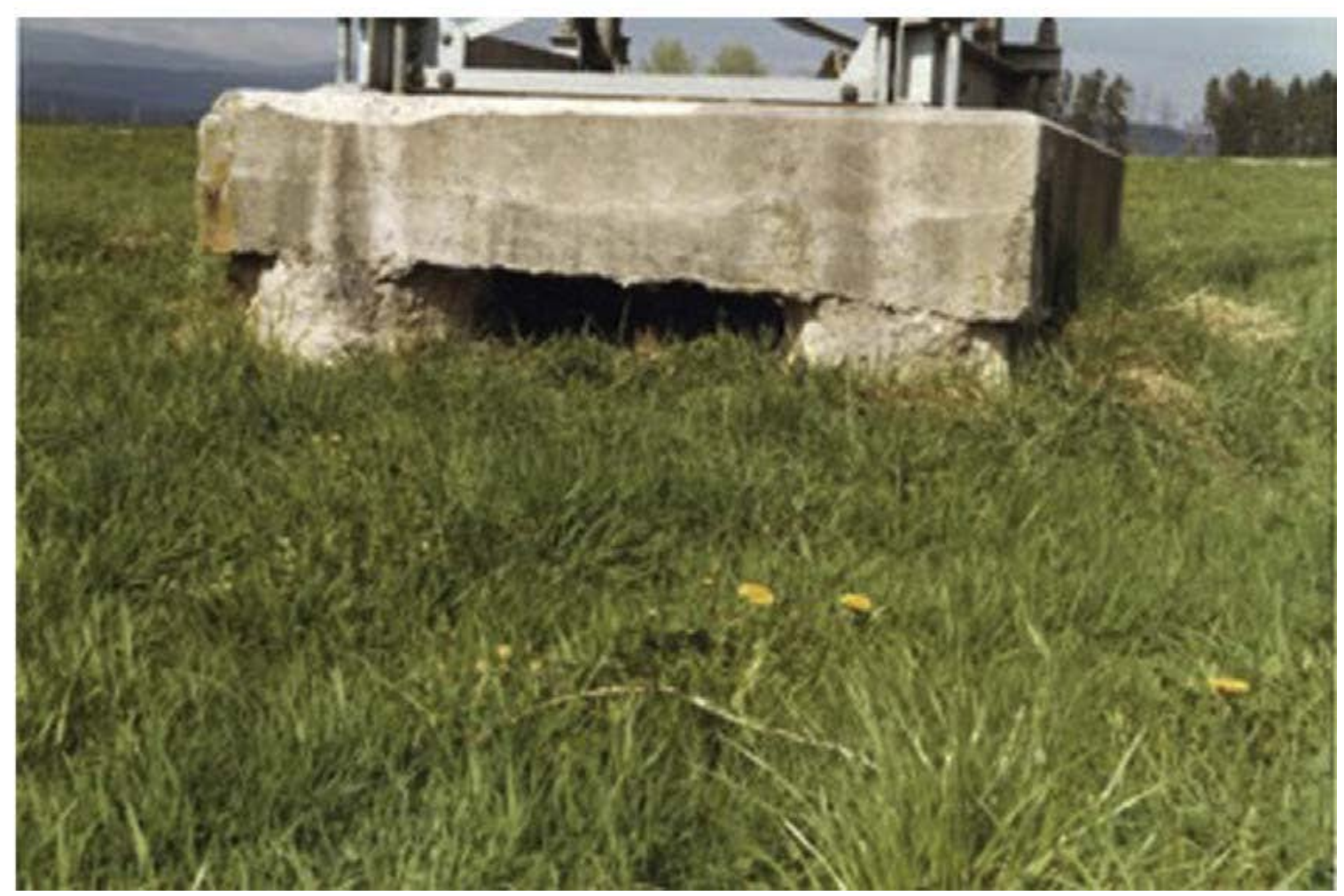

Fig. 12 


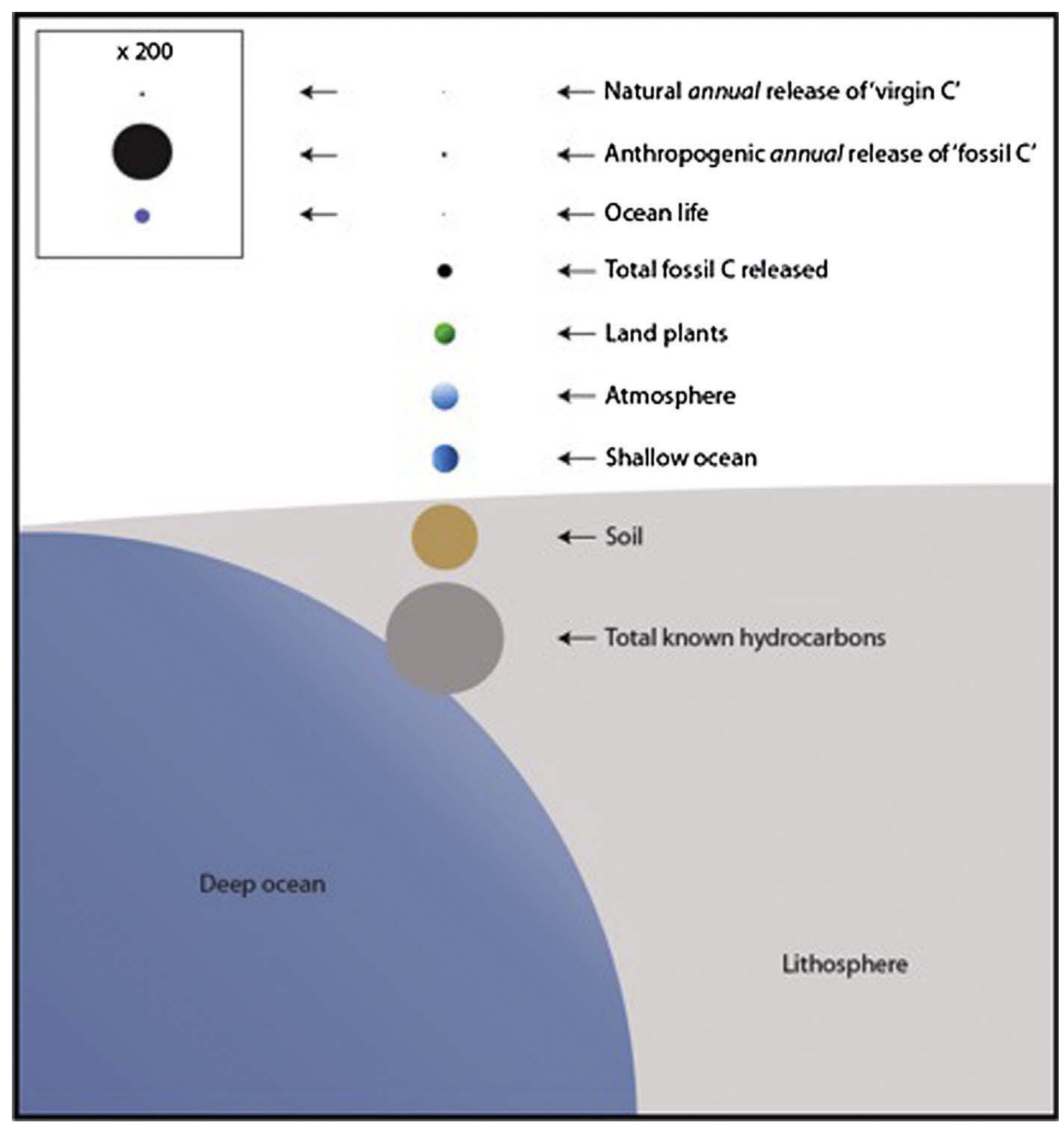

Fig. 13 


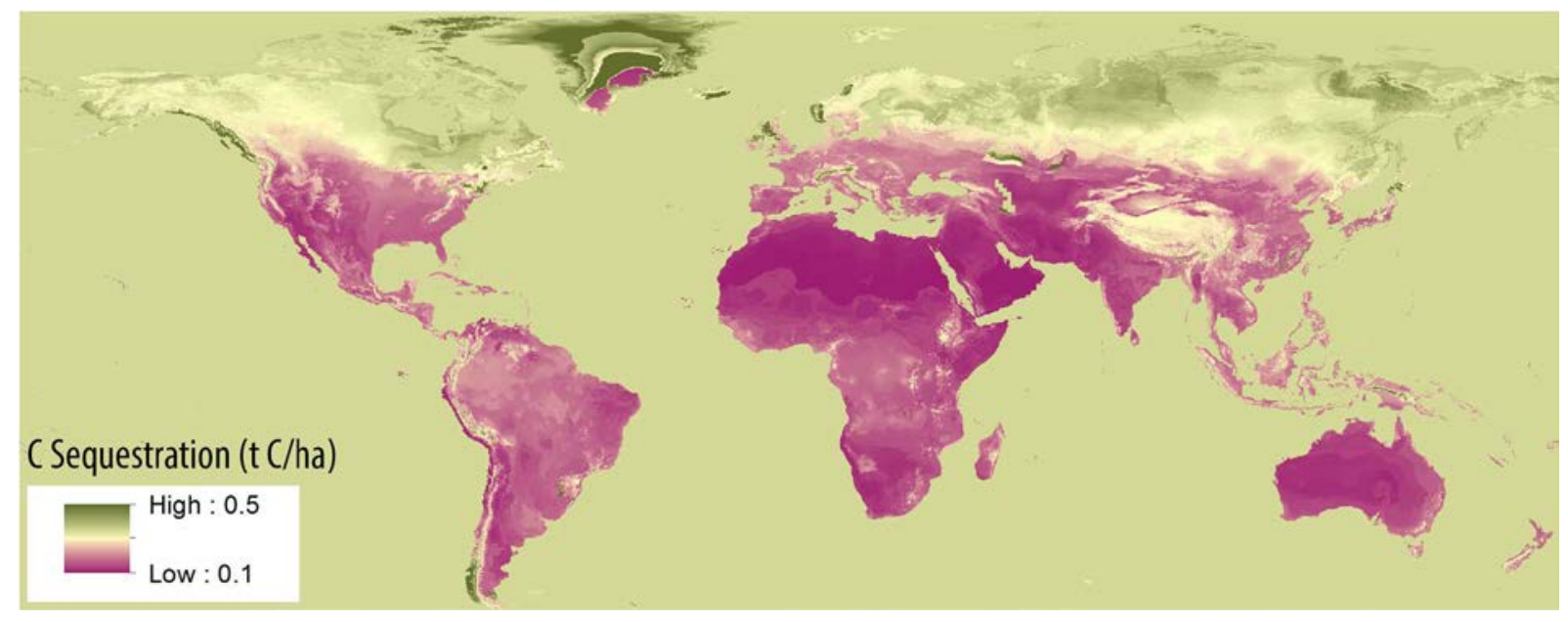

Fig. 14 


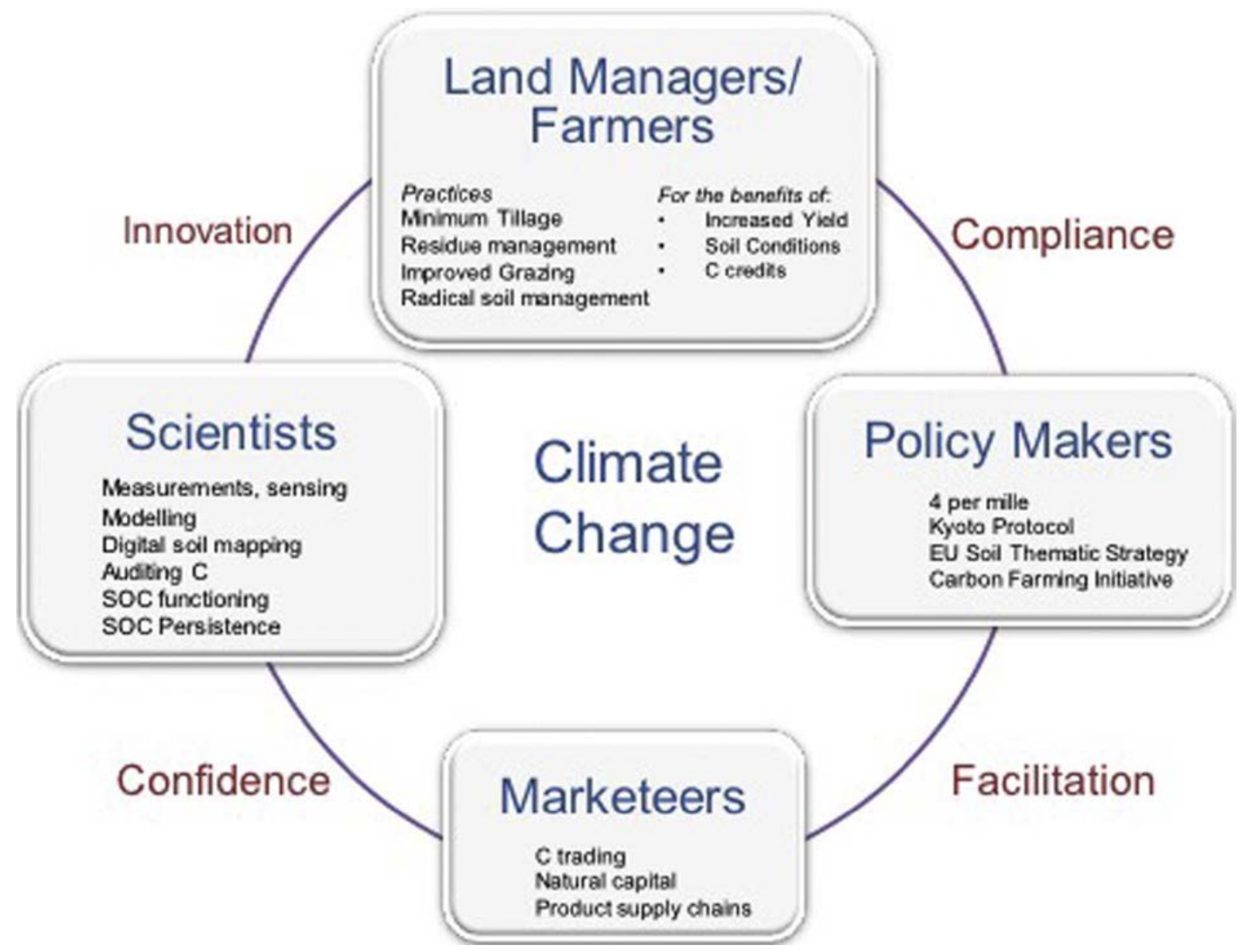

Fig. 15 
a) https://commons.wikimedia.org/wiki/File:Map-of-human-migrations.jpg\#filehistory

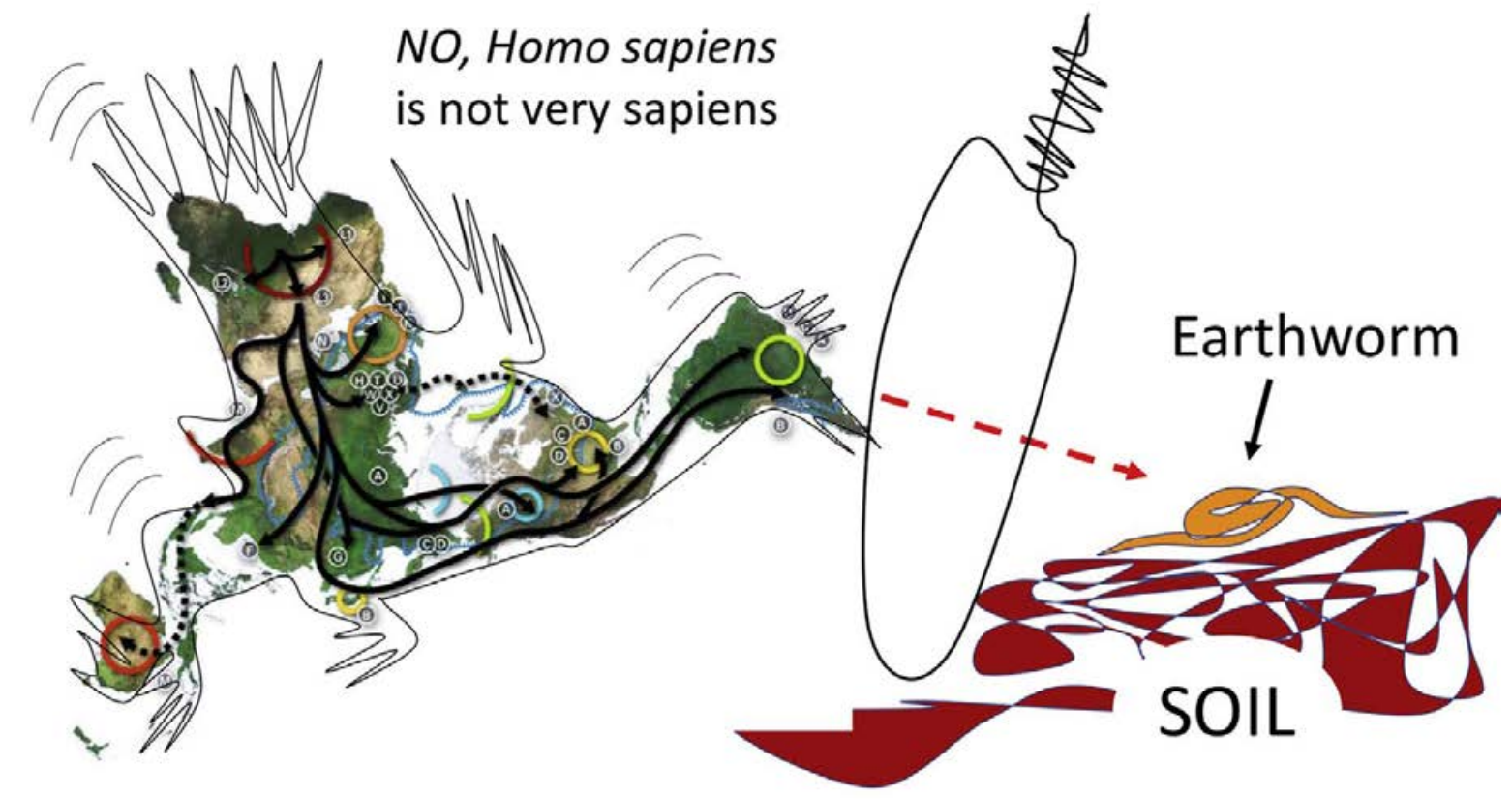

b) YES, Homo sapiens is sapiens enough

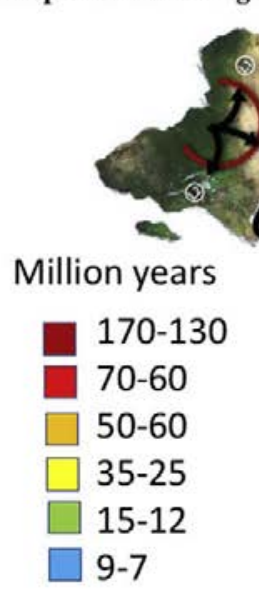

Fig. 16 